UNIVERSIDADE DE SÃO PAULO

HOSPITAL DE REABILITAÇÃO DE ANOMALIAS CRANIOFACIAIS

MÁRCIA CRISTINA ALMENDROS FERNANDES MORAES

CONTRIBUIÇÕES DAS ATIVIDADES EXPRESSIVAS E RECREATIVAS DURANTE A HOSPITALIZAÇÃO DA PESSOA COM FISSURA LABIOPALATINA

BAURU - SP 



\title{
CONTRIBUIÇÕES DAS ATIVIDADES EXPRESSIVAS E RECREATIVAS DURANTE A HOSPITALIZAÇÃO DA PESSOA COM FISSURA LABIOPALATINA
}

\author{
Autor: MÁRCIA CRISTINA ALMENDROS FERNANDES MORAES
}

Tese apresentada ao Hospital de Reabilitação de Anomalias Craniofaciais da Universidade de São Paulo para a obtenção do título de Doutor em Ciências da Reabilitação.

Área de Concentração: Fissuras Orofaciais e Anomalias Relacionadas

Orientador: Prof. Dr. José Alberto de Souza Freitas Coorientador: Dra. Telma Flores Genaro Motti

BAURU - SP 


\section{AUTORIZO A REPRODUÇÃO DESTE TRABALHO, POR QUALQUER MEIO CONVENCIONAL OU ELETRÔNICO, PARA FINS DE ESTUDO E PESQUISA, DESDE QUE CITADA A FONTE.}

\begin{tabular}{|l}
\hline Moraes, Márcia Cristina Almendros Fernandes \\
M791c \\
Contribuições das atividades expressivas e recreativas durante a \\
hospitalização da pessoa com fissura labiopalatina / Márcia Cristina \\
Almendros Fernandes Moraes. Bauru, 2012. \\
125p.; il.; 30 cm. \\
Tese (Doutorado em Ciências da Reabilitação- Área de concentração: \\
Fissuras Orofaciais e Anomalias Relacionadas) - Hospital de \\
Reabilitação de Anomalias Craniofaciais, Universidade de São Paulo. \\
Orientador: Prof. Dr. José Alberto de Souza Freitas \\
Coorientador: Dra. Telma Flores Genaro MOTTI \\
1.Fissura Labial 2. Fissura Palatina 3. Hospitalização 4. Recreação \\
5. Adolescente 6. Jovem Adulto 7. Reabilitação \\
CDD 342.085
\end{tabular}

Trabalho normalizado utilizando a obra abaixo, obedecendo à orientação da Secretaria Da Pós Graduação - HRAC/USP

Grigolli AAG. Metodologia do trabalho científico e recursos informacionais na área da saúde. São Paulo: Editora Santos, 2008. 


\section{FOLHA DE APROVAÇÃO}

\section{Márcia Cristina Almendros Fernandes Moraes}

Tese apresentada ao Hospital de Reabilitação de Anomalias Craniofaciais da Universidade de São Paulo para a obtenção do título de Doutor em Ciências da Reabilitação.

Área de Concentração: Fissuras Orofaciais e Anomalias Relacionadas

Aprovado em:

Banca Examinadora

Prof. Dr.

Instituição

Prof. Dr.

Instituição

Prof. Dr.

Instituição

Prof. Dr.

Instituição

Prof. Dr. José Alberto de Souza Freitas (Orientador)

Hospital de Reabilitação de Anomalias Craniofaciais-USP

Profa. Dra. Daniela Gamba Garib Carreira

Presidente da comissão de Pós-Graduação do HRAC-USP

Data de depósito da Tese junto à SPG: 



\section{Márcia Cristina Almendros Fernandes Moraes}

14 de Dezembro de 1967 Nascimento em Bauru/SP

$1988-1990$

$1990-1990$

$1996-1996$

$1999-2003$

$2005-2007$

2009- 2012

\section{FORMAÇÃO ACADÊMICA}

Graduação em História Licenciatura Plena - Universidade do Sagrado Coração (USC).

Graduação em Pedagogia - Complementação Pedagógica. Universidade de Marília (UNIMAR).

Especialização em Psicopedagogia (USC).

Graduação em Terapia Ocupacional (USC).

Mestre em Ciências da Reabilitação- Área: Distúrbios da Comunicação Humana- Hospital de Reabilitação de Anomalias Craniofaciais- Universidade de São Paulo- São Paulo (HRAC/USP).

Curso de Pós-Graduação em Ciências da Reabilitação na área das Fissuras Orofaciais e Anomalias Relacionadas, em nível de Doutorado no HRAC/USP. 



\section{FORMAÇÃO PROFISSIONAL}

$1989-2006$

$1997-2007$

$1997-2007$

$1997-2012$

1997 - Até hoje

$1999-2007$

2004- Até hoje

2006 - Até hoje

2011- Até hoje
Contratação no Hospital de Reabilitação de Anomalias Craniofaciais da Universidade de São Paulo - HRAC/USP como Técnico de Apoio Educativo.

Supervisora suplente das atividades de estagiários do Curso de Pedagogia (USC).

Supervisora suplente dos estágios no HRAC/USP dos alunos de Pedagogia da (USC).

Supervisora suplente do Programa de Aprimoramento Profissional em Reabilitação de Malformações Congênitas Fundação do Desenvolvimento Administrativo (FUNDAP), na área de Pedagogia do HRAC/USP.

Supervisora das atividades desenvolvidas no Serviço de Educação e Terapia Ocupacional (SETO) do HRAC/USP.

Supervisora no HRAC/USP do projeto "Universitários do Sorriso" dos alunos da disciplina Programas de Cidadania da (USC).

Membro do Grupo de Trabalho de Humanização (GTH) do Programa Nacional de Humanização de Assistência Hospitalar (PNHAH) do Sistema Único de Saúde (SUS).

Contratação no HRAC/USP como Terapeuta Ocupacional.

Supervisora do Estágio obrigatório Curricular do Curso de Terapia Ocupacional da USC. 



\section{APRESENTAÇÃO}

A experiência de 23 anos na área de atividades expressivas e recreativas com pacientes com fissura labiopalatinas (FLP) e sens acompanhantes, em geral familiares, tem propiciado oportunidades de ouvir muitas histórias, não publicadas.

Essas histórias e as situações vivenciadas na Recreação do Hospital de Reabilitação de Anomalias Craniofaciais da Universidade de São Paulo (HRAC/USP), Bauru/SP, despertaram un grande interesse em investigar um pouco mais esta população, que faz parte do nosso día a dia.

São exemplos, os relatos emocionantes de jovens que nunca participaram de peças de teatro na escola e depois da atividade durante a internação, sentiram-se encorajados, desafiaram preconceitos e começaram a participar.

A leitura em voz alta para toda a sala de aula, também um grande desafio, que esses jovens conseguiram superar a partir das atividades de dinâmicas de grupo.

Cantar no videokê é outra atividade mencionada por eles, atiada à oportunidade de participar na Recreação-HTAC/USP com outros pacientes e famitiares, fortalecendo-os a participar na sua comunidade.

Habilidades manuais e artisticas revelaram muitos talentos na Recreação-7HAC/USP, permitindo o exercicio da criatividade ao fazer algum objeto ou brinquedo, e despertando $\sigma$ interesse de muitos nessa área. São muitos os que relatam que tudo o que fizeram, guardam com carinho pela lembrança da hospitalização.

A convivência com outros pacientes também com FLP em decorrência das internações e cirurgias ao longo das diversas fases da vida, pessoas das várias regióes do Brasil e paises vizinhos, com profunda variedade sociocultural, é relatada por 

muitos como ocasião de grande crescimento enquanto ser humano.

Por outro lado, a preocupação do HRAC/USP com relação aos pacientes adolescentes e jovens adultos teve influência direta na definição do tema da pesquisa. A vivência com essas pessoas com FLP tem mostrado a necessidade de oferecer-thes atividades especificas para a sua idade e interesse, bem como de incentivar a participação dos acompanhantes junto com elas, favorecendo a aproximação e ovínculo famitiar.

Muitos relatos de pacientes que nunca tiveram a oportunidade de brincar com seus pais, fazer shows, teatros, mencionaram que estas atividades desenvolvidas no HRAC/USP revelaram sentimentos que eles desconheciam, tais como: os pais são engraçados, amigos e companheiros.

Ver o sorriso de um paciente que está com fome e sede em virtude do jejum para a cirurgia, ver o sorriso de um paciente com curativos, edemas e váríos desconfortos causados pela cirurgia, pela magia do teatro, dos shows musicais e de outras atividades em grupo proporcionadas na Recreação-HRAC/USP, foi $\sigma$ maior incentivo para buscar e, por meio da ciêncía, com esta pesquisa, mostrar a relevância desse trabalho tão peculiar, que ocorre durante a hospitalização do paciente. 



\section{DEDICATÓRIA}

Dedico este estudo a mens pais, Miguel e Leide, pelo grande incentivo, por todo amor dedicado a mim, minhas fithas e mew marido, por me ajudarem em todos os momentos de minha vida a nunca desistir dos mens sonhos. Por sempre cuidarem das minhas fithas com tanto amor e dedicação. Foram a base da minha formação pessoal. Obrigada pelos exemplos de honestidade, educação e respeito. Sem vocês eu não concretizaria este estudo. Peço a Deus que vocês continuem saudáveis e felizes.

Ao men esposo Douglas meu companheiro desde minha adolescência, também responsável pela minha formação pessoal e profissional, sempre me apoiow e me ajudow. Mew eterno amor, obrigada por fazer parte da minha vida.

As minhas fithas Anna Carolina e Julia, presentes mais belos que Deus me deu, sempre me apoiaram e estiveram ao lado. Mew eterno amor e gratidão.

A minha Sogra Elza que sempre me apoiou e cuidow de minhas fithas, sempre solidária, carinhosa e dedicada, men carinho especial e mew eterno agradecimento.

A minha família: Marcos, Edna e Marcellus, Marlyn, Karla, Ana Laura e Marcos e todos of meus familiares, obrigada por estarem sempre comigo, pelo carinho e amor. 



\section{AGRADECIMENTO ESPECIAL}

A Deus nosso Senhor que sempre ituminow os mens caminhos colocando sempre Nossa Senhora e Jesus Cristo ao meu lado me protegendo, me dando forças e fé para nunca desistir.

Ao Prof. Dr. José Alberto de Souza Freitas, tio Gastão, uma pessoa nobre, especial e dedicada, que abrí mão de si em prol das outras pessoas. Suas obras e ações ficarão para sempre registradas. Agradeço a oportunidade de ter convivido com $\sigma$ senhor. Obrigada por me incentivar nos estudos e no meu crescimento profissional. Que Deus o abençoe e o proteja sempre.

A minha coorientadora Dra.Telma Flores Genaro Mottu, uma mulher admirável e incansável. São tantas obrigaçöes (tarefas) que the foram atribuidas que é quase impossivel entender como você consegue fazer tudo com tanta competência, dedicação, responsabitidade, capricho e organização. Somente quem convive com você de perto sabe do seu trabalho e do seu potencial. Admiro demais a sua pessoa e aprendi muito com você nestes anos de estudo. Meus eternos agradecimentos pela grande paciência que teve comigo, por dedicar tantas horas preciosas da sua vida comigo, mesmo nos momentos mais dificeis você não me abandonou. A concretização deste estudo também é mérito seu. Receba minha eterna gratidão, admiração e respeito.

Dra. Maria José Monteiro Benjamin Buffa, minha querida amiga Zezé, fiel, companheira, sempre dedicada. Minha eterna mestra. Agradeço pela confiança, amizade e incentivo. Obrigada por abrir tantos caminhos e trilhar junto comigo por eles, sou eternamente grata a você pelo mew crescimento pessoal e profissional. 



\section{AGRADECIMENTOS}

A Dra. Lílian D'Aquino Tavano, uma grande amiga, mew eterno agradecimento por incentivar meus estudos e acreditar em mim. Obrigada por me ajudar a crescer enquanto pessoa $e$ profissionalmente. E também pelas importantes contribuiçóes a este estudo.

À Profa. Dra. Carla Cülene Baptista da Sílva, pela amizade, carinho e pelos ensinamentos durante a graduação e pelas valiosas sugestões a este estudo. Minha eterna gratidão por sempre me atender com muita atenção.

A Profa. Dra. Maria Amélia Ximenes Correia Lima, pelo companheirismo, amizade, pelos ensinamentos durante a graduação. Mew eterno agradecimento pela sua disponibitidade, atenção e pelas valiosas contribuiçóes a este estudo.

À Profa. Dra. Maria Inês Gândara Graciano, por fazer parte do mew crescimento acadêmico e profissional e por confiar no mew trabatho.

A Flávia Maria Ravagnani Neves Cintra pelas orientaçōes na parte estatistica durante este estudo, obrigada pela atenção, paciência e respeito.

A Profa. Dra. Daniela Gamba Garib, pela forma competente, serena e ética com que conduz o programa de Pós-Graduação. Obrigada pela confiança e respeito.

À Profa. Dra. Inge Kiemle Trindade, pela brithante forma com que conduziu a pós-graduação durante anos. 

Agradeço especialmente a equipe do Serviço de Educação e Terapia Ocupacional: Viviane Pereira Martins Gasparoto, Takeme Fugiwara, Lurdes da Silva Feriato, Izabela Bueno Trindade, Sheila Garcia Álvares, Christiane Ozaka Ferraz, Edenilson Antonio Raimundo e Karen Geisiete Campanini, pelo apoio, incentivo, confiança, amizade e orações, por sempre atenderem minhas solicitações, por cuidarem da Recreação e dos pacientes e famitiares com tanto carinho e competência e o principal, com muito amor. Agradeço imensamente a grande colaboração para a concretização de estudo. Sem vocês en jamais conseguiria conchir.

Ao Edenilson Antonio Raimundo, pelo companheirismo, fidelidade, pela grande contribuição durante várías etapas deste estudo, sem $\sigma$ seu apoio, tudo sería mais dificil, meu eterno agradecimento.

A Christiane Ozaka Ferraz, minha companheira nos estudos, minha eterna gratidão pelas valiosas contribuiçöes e por estar sempre pronta para me atender, meu carinho e minha gratidão.

A Viviane Pereira Martins Gasparoto, minha querida amiga, fiel e companheira, que sempre esteve ao meu lado principalmente nos momentos mais dificeis. Você mora no mew coração.

A minha grande amiga Thaisa Maria Silva Santos, eterna companheira e parceira profissional, você me ajudou muito durante este estudo e no mew crescimento pessoal e profissional, fomos grande parceiras no Hospital e tinhamos mitos planos que foram interrompidos, mas nossa amizade e carinho serão sempre preservados, você sempre estará no mew coração. 

Em memória da minha eterna amiga Márcia Zavaski Sabatella, grande companheira que sempre me incentivou nos estudos $e$ crescimento profissional, foi uma das grandes responsáveis pela implantação da Terapia Ocupacional no Hospital, sem ela ew não teria ousado tanto. Ela foi um anjo que passow em minha vida e permanecerá para sempre no mew coração.

A Gabriela Aparecida Prenharo, Carolina Biondo da Silva e Lystley Ferreira dos Santos grande colaboradoras durante algumas das fases deste estudo, é admirável a agitidade e competência de vocês. Tenho certeza que por onde vocês passarem deixarão registradas ótimas lembranças. Desejo que vocês brithem profissionalmente.

A Dra. Léa Sílvía Braga de Castro Sá, por sempre me atender com tanto carinho e pela grande colaboração nas correçóes deste estudo. Minha eterna admiração e respeito.

A Dra. Gisele da Silva Dalben, pela sua gentileza em fazer as traduções para o inglês, minha sincera gratidão.

Às bibliotecárias, Ana Aparecida Gomes Grigoli e Denise Giacheti pela colaboração no levantamento bibliográfico e orientações, a Rosemeire Aparecida Gimenes Botelho, Ricardo Pimentel Nogueira, Ana Regina Carvalho de Angelo e aos demais funcionários da Unidade de Ensino e Pesquisa pela atenção, educação, respeito e ética.

A toda equipe da Seção de Pós-Graduação: Andréia da Silva, Rogério da Silveira e Maria José Bento Lopes, pela atenção, respeito, companheirismo e pela forma gentil com que sempre me atenderam.

A toda a equipe dos Serviços de Prontuário de Pacientes e Informática Hospitalar, em especial Rosemari Frediani Motta, pela atenção, disponibilidade e dedicação. Muito obrigada! 

Ao Douglas Casoto por ajudar com váríos programas de informática que contribuiram com este estudo e por estar sempre pronto para me atender e orientar. Mew eterno agradecimento.

A Marilia Sayako Yatabe pela atenção, paciência e disposição para me ensinar sobre programas relacionados a citaçóes e referências bibliográficas.

Ao mew esposo Douglas que passow os finais de semana e noites a fio me ajudando na parte estatistica ou mesmo me fazendo companhia, você é realmente muito especial.

As minhas fithas Carol e Julia que muitas vezes leram minhas redações e deram opinióes, me ajudaram nas traduçóes e no preparo da aula, minhas queridas amigas e companheiras, vocês são demais.

A Néia minha secretáría que cuidow de minha casa com muito zelo e carinho, mens sinceros agradecimentos.

A todos os meus amigos que sempre estão presentes tanto nos momentos tristes como felizes de minha vida, muito obrigada.

A todos of pacientes deste estudo, mens sinceros agradecimentos pela confiança e contribuição. E aos famitiares que confiaram em mim. Aprendo muito com vocês e me sinto cada vez mais motivada para continuar buscando caminhos para a reabilitação da fissura labiopalatina. Que Dens os abençoe!

A todos os mens amigos do HRAC/USP que, de uma forma direta ow indireta, colaboraram para que eu concretizasse este estudo. 




\section{RESUMO}

Moraes MCAF. Contribuições das atividades expressivas e recreativas durante a hospitalização da pessoa com fissura labiopalatina [tese] Bauru: Hospital de Reabilitação de Anomalias Craniofaciais, Universidade de São Paulo; 2012.

Objetivo: Investigar junto aos adolescentes e jovens adultos com fissura labiopalatina (FLP) transforame que foram submetidos a cirurgias e internações no HRAC/USP e participaram de atividades expressivas e recreativas durante os períodos de hospitalização, a contribuição dessas atividades na sua vida familiar, social, afetiva, escolar e ocupacional.

Material e Método: A amostra foi composta por 53 pessoas em tratamento, com FLP transforame incisiva unilateral ou bilateral, sem outros comprometimentos, com idades entre 14 e 23 anos, residentes na Região Sudeste do Brasil e submetidos a três ou mais cirurgias no Hospital, sendo a última no período de 2005 a 2009. Foi aplicado um roteiro de entrevista especialmente elaborado pela pesquisadora, contemplando dados de identificação levantados nos prontuários clínicos, perguntas abertas e outras oferecendo alternativas, abordando as atividades expressivas e recreativas oferecidas aos pacientes durante suas hospitalizações. As entrevistas foram transcritas e as respostas tabuladas e submetidas à análise de conteúdo, sendo os dados analisados quantitativa e qualitativamente.

Resultados: Os entrevistados eram em sua maioria homens $(69,81 \%)$, apresentavam fissura transforame incisiva unilateral (66,04\%), tinham idades de 20 a 23 anos (45,28\%), procediam do estado de São Paulo (73,58\%), pertenciam ao estrato socioeconômico baixo superior (73,58\%), moravam com a família (86,79\%), tinham Ensino Médio incompleto ou completo $(67,93 \%), 62,26 \%$ continuavam estudando e 64,15\% exerciam alguma atividade profissional. A maioria $(73,58 \%)$ referiu praticar esportes e apenas um entrevistado informou não ter religião e não realizar atividades de lazer. Quase todos os entrevistados $(98,11 \%)$ iniciaram o tratamento no HRAC/USP antes dos 12 meses de idade e foram submetidos a 10 cirurgias em média e, 79,25\% ficaram internados cinco vezes ou mais. Jogos e dinâmicas de grupo foram as atividades mais lembradas por $69,81 \%$ e $49,06 \%$ dos entrevistados e, também, as mais marcantes, para 22,64\% e 20,75\%. Quanto à convivência, os entrevistados em geral consideraram ótima ou boa: familiar $(69,81 \%, 18,87 \%)$; com colegas da escola $(61,76 \%$, $29,41 \%)$ e com os professores $(44,12 \%, 44,12 \%)$. Os que trabalhavam também consideraram a convivência ótima ou boa: com colegas de trabalho $(52,94 \%, 41,18 \%)$ e com os superiores 

(44,12\%, 47,06\%). Também avaliaram como ótima ou boa: a convivência com colegas e conhecidos $(56,60 \%, 35,85 \%)$, a vida profissional $(41,18 \%, 50,00 \%)$, a vida social $(45,28 \%$, $43,40 \%)$, a convivência com o sexo oposto $(45,28 \%, 35,85 \%)$ e, finalmente, o estágio de reabilitação $(71,70 \%, 24,53 \%)$. A maioria dos entrevistados $(94,33 \%)$ considerou que as atividades contribuíram em suas vidas, 60,38\% relacionando ao crescimento pessoal e 32,08\% ao relacionamento interpessoal. De acordo com as respostas as contribuições ocorreram principalmente no âmbito social $(66,04 \%)$, auxiliando no enfrentamento do preconceito, melhora da autoimagem e da autoestima.

Conclusão: Os resultados permitiram verificar que as atividades expressivas e recreativas desenvolvidas durante as internações no HRAC/USP contribuíram para a vida dos entrevistados, favorecendo o crescimento pessoal e os relacionamentos interpessoais.

Descritores: fissura labial e fissura palatina; hospitalização; recreação; adolescente; jovem adulto; reabilitação; terapia ocupacional. 



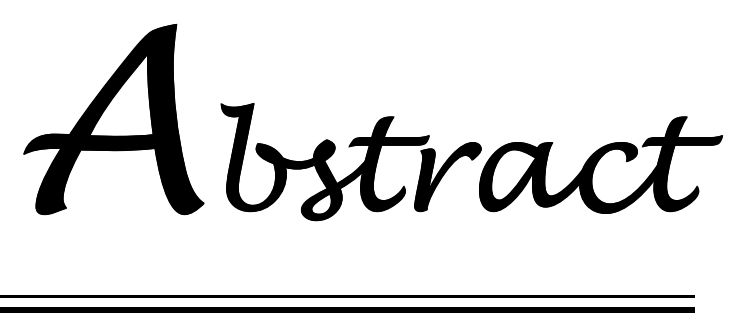





\begin{abstract}
Moraes MCAF. Contributions of expression and recreation activities during hospitalization of individuals with cleft lip and palate [thesis] Bauru: Hospital for Rehabilitation of Craniofacial Anomalies, University of São Paulo; 2012.
\end{abstract}

Objective: To investigate the contribution of expression and recreation activities during hospitalization periods for the family, social, affective, school and occupational life among adolescents and young adults with complete cleft lip and palate (CLP) submitted to surgeries and hospitalizations at HRAC/USP.

Material and Method: The sample was composed of 53 untreated individuals with complete unilateral or bilateral cleft lip and palate, without other disorders, aged 14 to 23 years, living in the Southeast region of Brazil and submitted to three or more surgeries at the Hospital, being the latter in the period from 2005 to 2009. An interview was especially designed and applied by the examiner, addressing demographic data obtained from the records, open and multiple choice questions, addressing the expression and recreation activities offered to the patients during hospitalization. The interviews were transcribed and the responses were plotted and analyzed as to their content, with quantitative and qualitative analysis of data.

Results: Most interviewees were males (69.81\%), with complete unilateral cleft lip and palate (66.04\%), aged 20 to 23 years (45.28\%), from the State of São Paulo (73.58\%), of upper low socioeconomic level (73.58\%), lived with their families $(86,79 \%)$, had incomplete or complete high school (67.93\%), 62.26\% were still studying and 64.15\% had some professional activity. Most individuals (73.58\%) referred sports practice and only one individual stated to have no religion and no leisure activities. Nearly all interviewees (98.11\%) initiated the treatment at HRAC/USP before the age of 12 months, were submitted to 10 surgeries in the average, and $79.25 \%$ were hospitalized five times or more. Games and group dynamics were the activities most remembered by $69.81 \%$ and $49.06 \%$ of interviewees, and also the most outstanding for $22.64 \%$ and $20.75 \%$. Concerning the friendship, the interviewees in general considered as excellent or good: familiar $(69.81 \%, 18.87 \%)$; with school mates $(61.76 \%, 29.41 \%)$ and with professors $(44.12 \%, 44.12 \%)$. Those who worked also considered the friendship excellent or good: with work colleagues $(52.94 \%, 41.18 \%)$ and with bosses $(44.12 \%, 47.06 \%)$. They also rated as excellent or good: the friendship with colleagues and acquaintances $(56.60 \%, 35.85 \%)$, professional life $(41.18 \%, 50.00 \%)$, social 

life $(45.28 \%, 43.40 \%)$, friendships with the opposite gender $(45.28 \%, 35.85 \%)$ and finally the rehabilitation stage $(71.70 \%, 24.53 \%)$. Most interviewees $(94.33 \%)$ considered that the activities contributed to their lives, $60.38 \%$ for personal growth and $32.08 \%$ for interpersonal relationships. According to the responses, the contributions occurred mainly in the social scope $(66.04 \%)$, aiding the coping of prejudice, enhancing the self-image and self-esteem.

Conclusion: The results evidenced that expression and recreational activities developed during hospitalizations at HRAC/USP contributed to the lives of interviewees, favoring their personal growth and interpersonal relationships.

Descriptors: cleft lip; cleft palate; hospitalization; recreation; adolescent; young adult; rehabilitation; occupational therapy. 



\section{LISTAS DE FIGURAS}

Figura 1 - Esquema do palato, identificando a posição do forame e os segmentos que se dividem, originando a fissura labiopalatina

Figura 2 - Tipos de fissura: A e B - Fissura no lábio unilateral, C e D Fissura transforame unilateral, E e F - Fissura transforame bilateral, G - Fissura palatina incompleta e H - Fissura palatina.

Figura 3 - Respostas dos sujeitos entrevistados sobre a convivência familiar, com os colegas da escola e com os professores, em percentual.

Figura 4 - Respostas dos sujeitos entrevistados, de acordo com a faixa etária e o sexo, avaliando o relacionamento com o sexo oposto, em percentual. 81

Figura 5 - Respostas dos sujeitos entrevistados, de acordo com a faixa etária, avaliando o estágio de reabilitação, em percentual. 84 



\section{LISTAS DE TABELAS}

Tabela 1 - Sujeitos entrevistados, de acordo com a faixa etária e o sexo. 57

Tabela 2 - Pais e mães dos sujeitos entrevistados, de acordo com nível de escolaridade.

Tabela 3 - Sujeitos entrevistados, de acordo com a faixa etária e o nível de escolaridade.

Tabela 4 - Sujeitos entrevistados que trabalhavam, de acordo com a faixa etária e o sexo.

Tabela 5 - Sujeitos entrevistados que trabalhavam, de acordo com o sexo e o tipo de ocupação.

Tabela 6 - Respostas dos sujeitos entrevistados, de acordo com as atividades de lazer informadas, se grupal ou individual.

Tabela 7 - Sujeitos entrevistados, de acordo com a faixa etária, a fissura labiopalatina incisiva unilateral ou bilateral e o número médio de cirurgias realizadas.

Tabela 8 - Respostas dos sujeitos entrevistados, de acordo com as atividades em que participaram durante as hospitalizações

Tabela 9 - Respostas dos sujeitos entrevistados sobre a atividade considerada marcante, de acordo com o sexo.

Tabela 10 - Respostas dos sujeitos entrevistados sobre a convivência familiar, com os colegas da escola e com os professores.

Tabela 11 - Respostas dos sujeitos entrevistados sobre a convivência com os colegas e com os superiores no trabalho.

Tabela 12 - Respostas dos sujeitos entrevistados avaliando a vida profissional e social

Tabela 13 - Respostas dos sujeitos entrevistados, de acordo com a faixa etária e o sexo, avaliando o relacionamento com o sexo oposto.

Tabela 14 - Respostas dos sujeitos entrevistados, de acordo com a faixa etária, avaliando o estágio de reabilitação.

Tabela 15 - Respostas dos sujeitos entrevistados, sobre a contribuição das atividades expressivas e recreativas durante a internação para a vida. 



\section{LISTA DE SIGLAS}

A

AVD

BI

BS

CBO

CEP

CPRLLP/FOB/USP

Dieese

FOB/USP

FLP

HPRLLP/USP

HRAC/USP

MI

M

MS

OMS

SETO

TCLE

TO

TV
Alta

Atividades de vida diária

Baixa Inferior

Baixa Superior

Classificação Brasileira de Ocupações

Comitê de Ética em Pesquisa

Centro de Pesquisa e Reabilitação de Lesões Lábio-Palatais da Faculdade de Odontologia de Bauru da Universidade de São Paulo

Departamento Intersindical de Estatística e Estudos Socioeconômicos

Faculdade de Odontologia de Bauru da Universidade de São Paulo

Fissura Labiopalatina

Hospital de Pesquisa e Reabilitação de Lesões Lábio-Palatais da Universidade de São Paulo

Hospital de Reabilitação de Anomalias Craniofaciais da Universidade de São Paulo

Média Inferior

Média

Média Superior

Organização Mundial de Saúde

Serviço de Educação e Terapia Ocupacional

Termo de Consentimento Livre e Esclarecido

Terapia Ocupacional ou Terapeuta Ocupacional

Televisão 



\section{SUMÁRIO}

1 INTRODUÇÃO

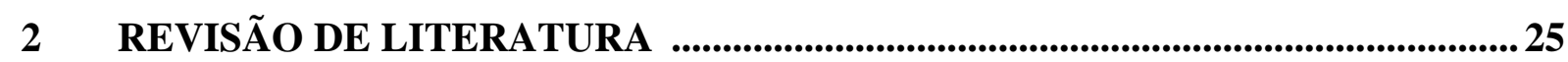

2.1 As fissuras labiopalatinas (FLP) e as condutas terapêuticas ........................................ 27

2.2 As fissuras labiopalatinas (FLP) e suas implicações do nascimento à

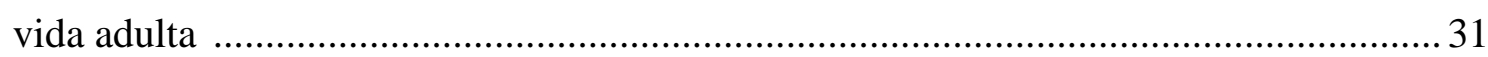

2.3 Atividades expressivas e recreativas na hospitalização da pessoa com

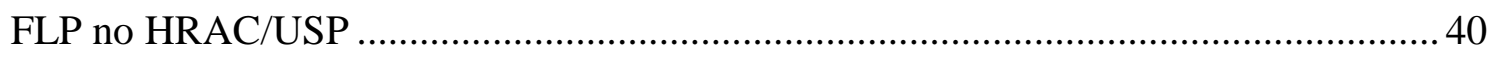

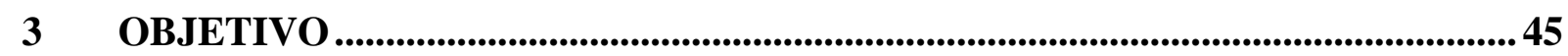

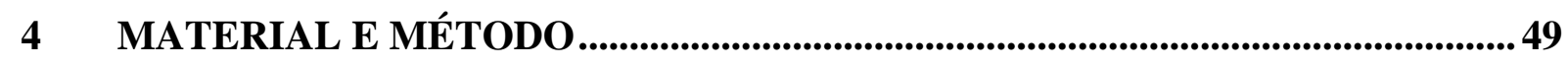

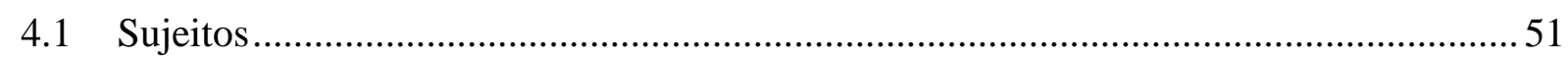

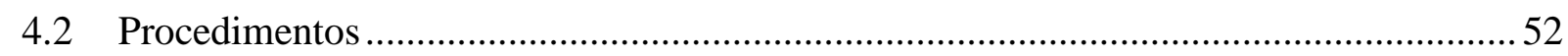

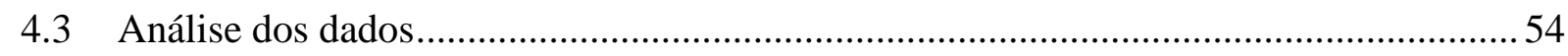

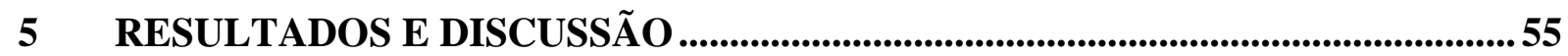

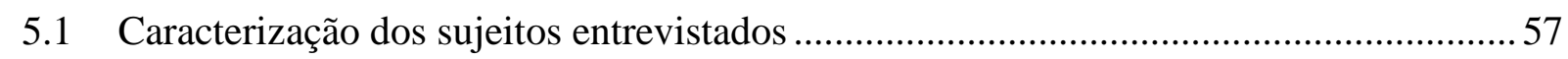

5.2 Informações sobre o tratamento no HRAC/USP e atividades

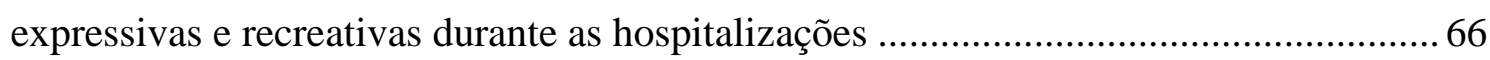

5.3 Convivência e relacionamentos sociais.......................................................................... 70

$6 \quad$ CONCLUS

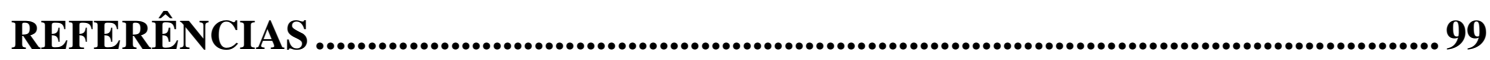

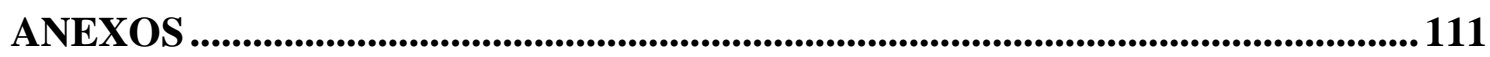



1 Introdução 



\section{INTRODUÇÃO}

No início de 1967, um estudo epidemiológico de profissionais da Faculdade de Odontologia de Bauru, da Universidade de São Paulo (FOB/USP), em Bauru/SP, revelou que uma em cada 650 crianças nascidas apresentava fissura de lábio e/ou palato. Os profissionais começaram a prestar assistência a estes indivíduos, dando origem ao Centro de Pesquisa e Reabilitação de Lesões Lábio-Palatais da Faculdade de Odontologia de Bauru da Universidade de São Paulo, Bauru/SP (CPRLLP/FOB/USP), integrando serviços de ensino, pesquisa e assistência social, o qual passou a ser conhecido carinhosamente como "Centrinho" (Freitas et al, 2012 b).

Em 1976, esse Centro foi transformado em uma unidade hospitalar autônoma: Hospital de Pesquisa e Reabilitação de Lesões Lábio-Palatais da Universidade de São Paulo, Bauru/SP (HPRLLP/USP), o qual se destacou pela excelência do atendimento, na USP e, como referência mundial pela Organização Mundial da Saúde (OMS). Com a ampliação dos casos atendidos, o nome do Hospital foi alterado em 1998 para Hospital de Reabilitação de Anomalias Craniofaciais (HRAC/USP) (Freitas et al, 2012 b).

Em toda essa trajetória do HRAC/USP, destaca-se a preocupação com a reabilitação global do paciente com deformidade craniofacial. As fissuras labiopalatinas (FLP) são as mais frequentes dessas malformações e requerem um longo período de tratamento, o que significa inúmeras internações, cirurgias e atendimentos ambulatoriais (Freitas et al, 2012 b).

É um complexo processo de reabilitação que afeta, além dos pacientes, as famílias, que experimentam um estresse crônico de ordem física, emocional e social. Assim, os profissionais que atuam no tratamento das FLP necessitam aliar conhecimentos técnicos e humanização, ao realizar os procedimentos no cotidiano (Bastos, Gardenal e Gobo 2008).

No HRAC/USP as atividades expressivas e recreativas desde a década de 70 estiveram presentes durante a hospitalização, buscando oferecer um atendimento humanizado aos pacientes e familiares, no Serviço de Educação e Terapia Ocupacional (SETO) (Moraes, 2007).

A influência dessas atividades expressivas e recreativas durante a hospitalização no processo de recuperação cirúrgica foi estudada por Moraes; Buffa; Motti (2009), que 
analisaram a visão de 138 familiares de crianças de sete a 12 anos, com FLP. Os resultados mostraram que tais atividades favorecem a criança e os familiares, reduzindo o estresse, proporcionando sentimentos positivos a ambos e auxiliando a adaptação e o restabelecimento físico e emocional. Foi evidenciada a importância desse apoio frente ao grande número de procedimentos cirúrgicos e hospitalizações a que as crianças com FLP estão sujeitas. As opiniões dos familiares motivaram a realização de novos estudos, envolvendo outras faixas etárias e buscando conhecimentos sobre outros aspectos, tais como a contribuição das atividades expressivas e recreativas após as hospitalizações, para a vida de adolescentes e jovens adultos com FLP.

O presente estudo vem atender essa motivação, contribuindo para ampliar conhecimentos a respeito dos efeitos psicossociais da FLP, da reabilitação e subsidiar profissionais da saúde, na implantação de atividades expressivas e recreativas durante a hospitalização.

A revisão a seguir aborda as FLP, condutas terapêuticas, os aspectos psicossociais envolvidos no desenvolvimento do indivíduo com fissura do nascimento até a fase adulta e apresenta as atividades expressivas e recreativas oferecidas durante a hospitalização no HRAC/USP aos adolescentes e jovens adultos. 
2 Revisãode

Literatura 



\section{REVISÃO DE LITERATURA}

\subsection{As fissuras labiopalatinas (FLP) e as condutas terapêuticas}

As anomalias craniofaciais identificadas como FLP são comuns entre as malformações que atingem a face do ser humano e podem ocorrer a cada 650 crianças nascidas no Brasil (Nagem Filho, Morais e Rocha 1968). Outros estudos apontaram por volta de 1,7 para cada 1000 nascidos vivos, com variação étnica e geográfica (Mossey et al, 2009).

As fissuras são estabelecidas na vida intrauterina entre a quarta e a $12^{\mathrm{a}}$ semana de gestação, sendo a etiologia atribuída tanto à hereditariedade quanto aos fatores teratogênicos ou ambientais (Silva-Filho e Freitas, 2007). Vários indicadores estão envolvidos na etiologia da FLP, físicos, químicos, biológicos ou agentes que atuam sobre o processo celular. $\mathrm{O}$ mecanismo etiopatogênico, relacionado a um padrão de herança multifatorial, que requer a interação entre determinantes genéticos, ambientais e associação de fatores, transmite a identificação de genes específicos que determinam esta anomalia (Mossey et al 2009, Dixon, Beaty e Murray 2011 e Freitas et al 2012b).

A descoberta de genes responsáveis por síndromes envolvendo fissura de lábio e palato nos aspectos clínicos (fissuras sindrômicas) também permitiu uma compreensão sobre a etiologia de seu tipo mais comum, a não-sindrômica. Ainda que esse conhecimento seja insuficiente atualmente, é importante por ter como objetivo o aconselhamento genético e o desenvolvimento de futuras medidas preventivas (Dixon, Beaty e Murray 2011).

Os efeitos das FLP sobre a fala, a audição, a aparência física e problemas psicossociais podem demandar um longo período para o restabelecimento da saúde e integração social. Normalmente, crianças com estes distúrbios precisam de cuidados multidisciplinares desde o nascimento até a idade adulta e têm maior morbidade e mortalidade em toda vida do que os indivíduos não afetados (Mossey et al, 2009).

Essas malformações que compreendem o lábio e o palato variam em extensão e amplitude. A Figura 1 permite visualizar como o palato pode ser segmentado na presença da fissura. 

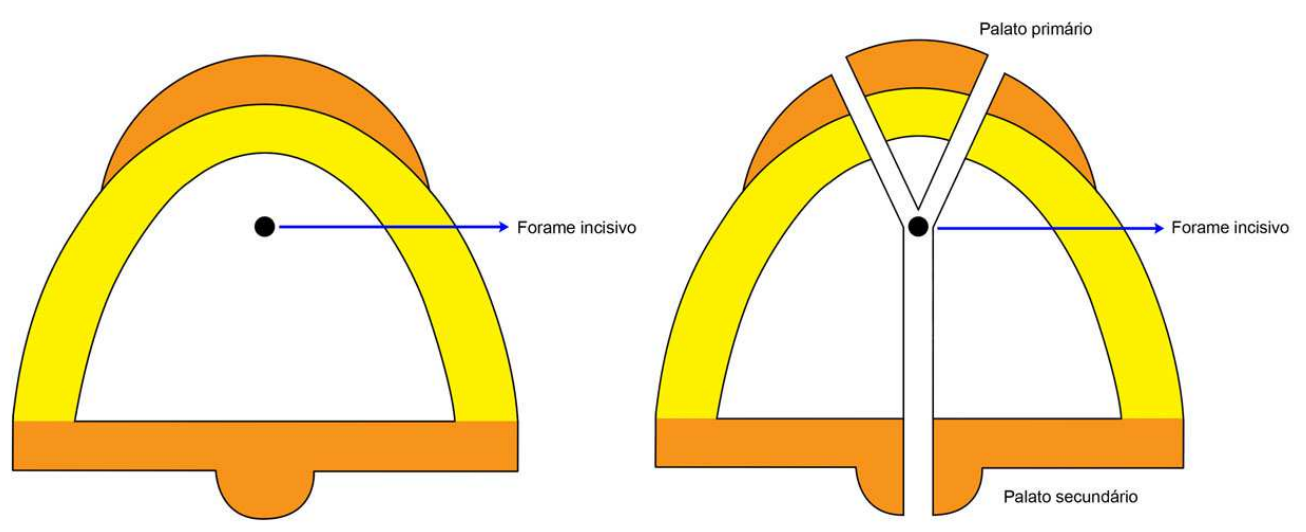

Fonte: Aiello CA, Silva Filho OG, Freitas JAS. Fissuras labiopalatais: uma visão contemporânea do processo reabilitador. In: Mugayar LRF. Pacientes portadores de necessidades especiais: manual de odontologia e saúde oral. São Paulo: Pancast; 2000. p.111-39.

Figura 1 - Esquema do palato, identificando a posição do forame e os segmentos que se dividem, originando a fissura labiopalatina.

As FLP podem ser classificadas de formas diversas. No HRAC/USP é utilizada a classificação de Spina et al (1972) modificada por Silva Filho et al (1992), a qual considera quatro grupos: fissura pré-forame incisiva que pode ser completa e incompleta, unilateral, bilateral ou mediana; fissura transforame incisiva, que pode ser unilateral ou bilateral; fissura pós-forame incisiva que pode ser completa ou incompleta, e fissuras raras da face, que envolvem outras estruturas além do lábio e palato. A Figura 2 ilustra os tipos de FLP.
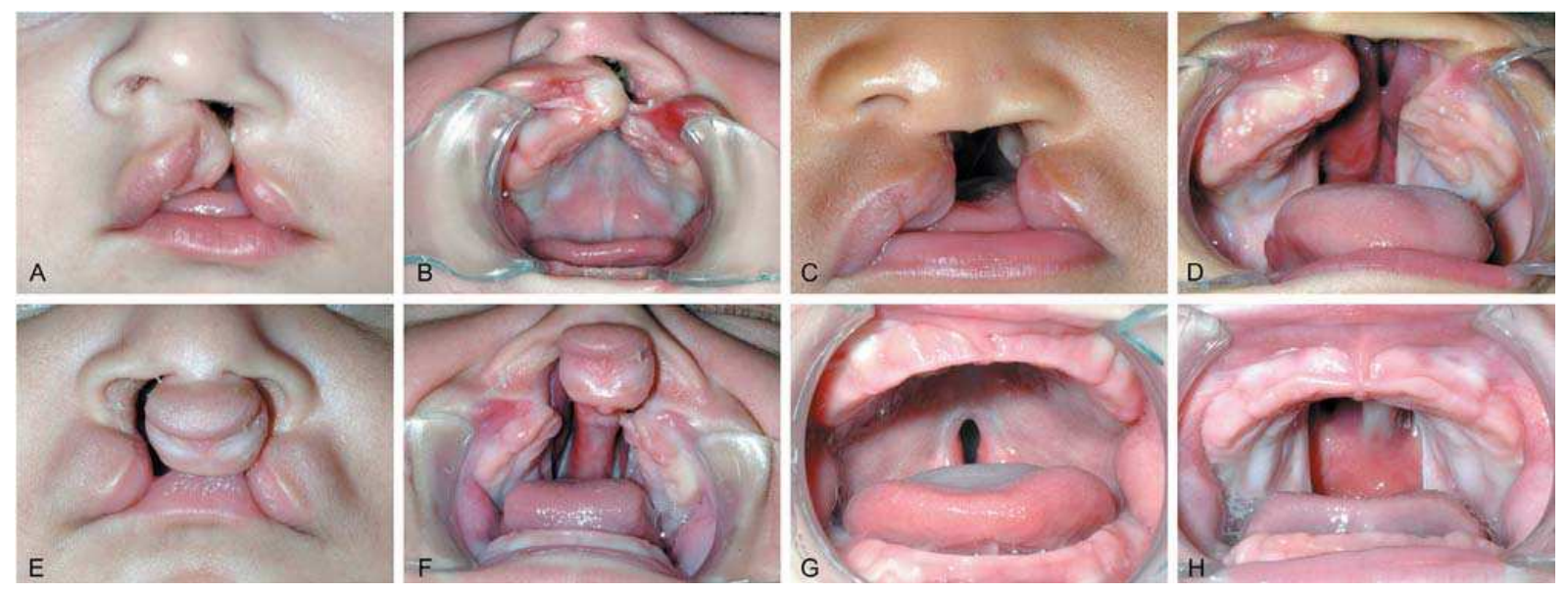

Fonte: Freitas JAS, Neves LT, Almeida ALPF, Garib DG, Trindade-Suedam IK, Yaedú RYF, et al. Rehabilitative treatment of cleft lip and palate: experience of the Hospital for Rehabilitation of Craniofacial Anomalies/USP (HRAC/USP)-Part 1: overall aspects. Journal of Applied Oral Science. 2012b;20(1):9-15.

Figura 2 - Tipos de fissura: A e B - Fissura no lábio unilateral, C e D - Fissura transforame unilateral, E e F Fissura transforame bilateral, G - Fissura palatina incompleta e H - Fissura palatina. 
As fissuras transforame incisivas são totais, acometem lábio, rebordo alveolar, palato primário e secundário até a úvula. Conforme se apresenta, uni ou bilateral, a maxila é dividida em dois ou três segmentos e a separação entre eles mostra a amplitude da fissura que, quanto maior, demandará mais tempo de tratamento. A bilateral representa a forma mais severa das FLP, pois envolve tanto os aspectos estéticos como os funcionais. Uma característica típica da face de pessoas com esse tipo de fissura é o segmento do lábio com projeção anterior da prémaxila, bem como o nariz com redução acentuada da columela e abaixamento do ápice (SilvaFilho e Freitas, 2007).

Para a compreensão da pessoa com FLP como um ser em sua totalidade e a reabilitação integral, é necessário um tratamento distinto e específico para cada caso, bem como, uma equipe multiprofissional e interdisciplinar que aborde os aspectos funcionais, estéticos e psicossociais (Graciano, Tavano e Bachega 2007).

A avaliação inicial é realizada por uma equipe composta por um cirurgião plástico, um odontólogo e um fonoaudiólogo para diagnosticar o tipo de fissura. Durante esse atendimento em equipe, os pais são informados sobre a abordagem terapêutica a ser seguida e, depois, recebem orientação de outras áreas, tais como: pediatria, clínica geral, enfermagem, serviço social, nutrição (menores de dois anos), otorrinolaringologia (acima de quatro anos), genética. Quando indicado pelos profissionais, o paciente é atendido também nas áreas de cardiologia, neurologia, psicologia, odontologia, terapia ocupacional e fisioterapia. Estes atendimentos complementares visam orientar os pais sobre as diversas consequências da fenda e como devem gerenciar cada uma delas (Universidade de São Paulo, 2008 e Freitas et al, 2012b).

Freitas et al (2012b) referem que, de acordo com cada tipo de fissura, os profissionais do HRAC/USP atuam sobre protocolos que, em geral, determinam os tratamentos a serem seguidos; porém, respeitando a singularidade e as expectativas dos pacientes e seus familiares. Estas abordagens terapêuticas são baseadas na experiência de 45 anos no tratamento de anomalias craniofaciais e foram estabelecidas pela análise dos resultados durante as várias fases de reabilitação.

A queiloplastia, que é a cirurgia de reparação do lábio, ocorre a partir dos três meses de idade e a palatoplastia, que é a reconstrução do palato, acontece a partir dos 12 meses, desde que a avaliação da criança demonstre que seu estado de saúde permite a realização do procedimento. No período entre estas duas cirurgias tem sequência o acompanhamento ambulatorial na odontologia, são realizados exames laboratoriais, avaliações e orientações 
com serviço social, enfermagem, fisioterapia, terapia ocupacional, nutrição e psicologia. Nos casos de fissuras que afetam o palato, durante o pré e o pós-operatório da palatoplastia até três anos de idade, o paciente deve ser avaliado pela fonoaudiologia para averiguar sua condição auditiva e a necessidade de intervenção terapêutica (Universidade de São Paulo, 2008 e Freitas et al, 2012b).

Por volta dos seis anos de idade, os pacientes com qualquer tipo de fenda são avaliados quanto ao resultado das cirurgias primárias para determinar a necessidade de um segundo estágio, ou cirurgias secundárias. Na fissura de lábio, a queiloplastia secundária pode ser necessária para correção estética do lábio e a fissura palatina pode exigir a faringoplastia, com o principal objetivo de aprimorar a fala ou corrigir uma fístula, que é uma pequena fenda que pode ficar no palato após a palatoplastia e que também pode prejudicar a fala (Freitas et al, 2012b).

$\mathrm{Na}$ área odontológica, o paciente é avaliado pela ortodontia preventiva para análise do desenvolvimento craniofacial e definição do plano de tratamento a ser seguido. Diferentes especialidades da odontologia seguem realizando os procedimentos necessários, responsáveis por grande parte da reabilitação estética, intervindo nas discrepâncias maxilomandibulares e anomalias dentárias (Freitas et al, 2012b).

O tratamento ortodôntico de indivíduos com FLP requer as seguintes fases do protocolo de atendimento: ortodontia antes do enxerto ósseo alveolar; enxerto ósseo alveolar secundário; ortodontia após enxerto ósseo alveolar; cirurgia ortognática; finalização e retenção (Freitas et al, 2012a).

O enxerto ósseo alveolar secundário é um tratamento utilizado no HRAC/USP que propicia a estabilidade dos segmentos maxilares, possibilitando a movimentação ortodôntica e a sequência do tratamento reabilitador. Essa cirurgia deve ocorrer entre nove e 12 anos de idade, período da irrupção do canino permanente próximo à fissura (Ibrahim, et al 2004).

A cirurgia ortognática é indicada para indivíduos que apresentam problemas de oclusão, mastigação e uma desagradável estética facial. Tem o objetivo de colocar a maxila e a mandíbula em uma relação adequada, corrigindo os problemas mencionados. Deste modo, exclui as deformidades apresentadas na face, melhorando a estética facial (Freitas et al, 2012a). 


\subsection{As fissuras labiopalatinas (FLP) e suas implicações do nascimento à vida adulta}

As FLP podem representar um grande fardo para a saúde, qualidade de vida e bemestar socioeconômico dos indivíduos afetados e suas famílias, necessitando de serviços de reabilitação de custo significativo (Wehby e Cassell, 2010). Entender as consequências dessas malformações é importante para identificar insatisfações (com a aparência física, fala, discriminação social, entre outras) e sugerir políticas públicas que possam amenizar as dificuldades por elas geradas, nos níveis individual, familiar e social.

Wehby e Cassell (2010) realizaram um trabalho de revisão em pesquisas que avaliaram o impacto da FLP na qualidade de vida e questões socioeconômicas. De acordo com os autores, vários estudos identificaram um aumento da sobrecarga de indivíduos com FLP, mas estes resultados não foram muito confiáveis pelo tamanho pequeno da amostra. Destacaram a importância de expandir prestadores de cuidados e pesquisadores para identificar dados necessários e melhoria dos sistemas de coleta, bem como investir na continuidade da análise do impacto das FLP durante todas as fases da vida.

O nascimento de uma criança com FLP causa uma série de sentimentos e reações de fracasso à sua família, medo de outra deficiência associada, preocupação de apresentar o bebê à sociedade e receio das gestações futuras. Daí a importância de fornecer apoio e orientação, de acordo com a necessidade das famílias, para assegurar um melhor enfrentamento e adaptação a esta nova situação (Speltz 1997, Byrnes et al 2003, Perry 2004 e Rafacho, 2012).

Sentimentos de choque, ansiedade, perda e culpa, são atribuídos à falta de habilidade temporária, em especial da mãe, para lidar com esse filho especial. Logo na identificação da condição da criança, a família pode enfrentar essa fase, vivenciá-la por curto ou longo período ou, ainda, nunca sair dela. A assistência aos familiares é muito importante e cabe aos profissionais da saúde fazer intervenções, aconselhamento e ou treinamento de habilidades de interação social, para que a autoestima e autoconfiança social aumentem. Quando os familiares aceitam a condição da criança, compreendem que o processo de reabilitação é longo e difícil e se predispõem a colaborar efetivamente e a participar de todo o processo, os reflexos são observados na integração do indivíduo no ambiente familiar e nos diferentes ambientes sociais (Tavano 1994, Turner, Rumsey e Sandy 1998 e Colares e Richman 2002).

O ambiente familiar é fator importante na reabilitação da pessoa que nasce com malformação, pois as atitudes, expectativas e o apoio dos pais podem influenciar a percepção 
sobre sua condição. A família é o primeiro referencial na existência do ser humano, por meio do qual é construída a primeira identidade e promovida a inserção no meio social, processo que envolve as questões emocionais, culturais e socioeconômicas. Assim, quando se trata de reabilitação de pessoas com FLP, é necessário incluir a participação efetiva da família no processo (Graciano, Tavano e Bachega, 2007 e Rafacho, 2012).

Logo após o nascimento da criança com FLP, os familiares deveriam receber informações e serem expostos a expectativas realistas. Durante todo o estágio de reabilitação, deveriam continuar a receber informações e orientações (Colares e Richman, 2002 e Rafacho, 2012).

O tratamento da pessoa com FLP se estende da primeira infância até a adolescência. Múltiplas cirurgias ocorrem ao longo desses anos e, para lidar com essas intervenções e outras que são ditadas pela gravidade da malformação, a família também pode precisar de ajuda. $\mathrm{O}$ paciente pode precisar de terapia da fala, apresentar infecções de ouvido, dificuldades de aprendizagem e realizar vários tratamentos ortodônticos. O resultado final destes tratamentos e intervenções deve ser um adolescente, criança ou adulto reabilitado e que contribua como membro da sociedade, em cada fase de desenvolvimento (Kapp-Simon, 2002).

$\mathrm{O}$ apoio psicológico se faz necessário para permitir que a criança cumpra as metas e atinja a reabilitação; mas, para que isso ocorra, o papel da família, da escola, dos cirurgiões, entre outros envolvidos no tratamento, é fundamental. Esses envolvidos devem demonstrar à criança a sua capacidade para lidar com o tratamento da fissura e alertá-la sobre o que pode ganhar com sua experiência de vida (Kapp-Simon, 2004).

Byrnes et al (2003), com a finalidade de ajudar profissionais a se comunicarem a respeito das fissuras de lábio e ou palato, com pais de crianças com essas deformidades, conduziram um estudo para conhecer as experiências e preferências desses pais. Os resultados revelaram que os pais queriam ter um maior controle da conversa, que os profissionais de saúde mostrassem mais carinho e confiança, lhes dessem mais oportunidade para falar e mostrar sentimentos, concluindo que os pais estavam insatisfeitos.

Baker et al (2009) conduziram um estudo para analisar o papel das estratégias de enfrentamento dos pais de crianças e jovens adultos com FLP e verificaram o impacto da FLP na família de pacientes, os níveis de ajustamento e sofrimento psíquico, em relação à idade, tipo de fissura ou outros problemas de saúde relatados. Os autores perceberam que o apoio 
dos amigos e familiares contribuía para um impacto menos negativo da FLP na família, menor sofrimento psíquico e melhor ajustamento. Quando tinham um filho mais novo com problemas de saúde, a FLP foi associada a um maior impacto sobre a família e os autores concluíram que o modo como os pais lidam com a condição de seus filhos e os níveis de apoio recebido, podem ter implicações para os cuidadores, a unidade familiar e os profissionais que os atendem.

Outro aspecto, que também deve ser considerado, são as várias cirurgias a que as pessoas que nascem com FLP devem ser submetidas e os vários dias que passam em hospitais e serviços de saúde. É um processo que tem início na infância e previsão de término na fase adulta (Universidade de São Paulo, 2008).

A hospitalização é uma experiência que provoca desestabilidade emocional e, consequentemente, estresse, exigindo a adaptação da pessoa a diferentes ambientes. Especialmente no caso de crianças e adolescentes, são situações que podem ser amenizadas com a provisão de certas condições: disponibilidade afetiva dos profissionais da saúde, atividades expressivas e recreativas e a presença dos familiares, entre outros (Carney 2003, Coyne 2006 e Basso 2010).

Salmela et al (2010) realizaram um estudo com foco na expressão da própria criança hospitalizada sobre os medos e as estratégias de enfrentamento em comparação com crianças do jardim da infância. As crianças que foram entrevistadas no hospital mencionaram que utilizavam o brincar e as crianças do jardim de infância mencionaram a presença dos pais. Este estudo mostrou a importância de suporte para auxiliar as crianças nas suas estratégias de enfrentamento, tais como, presença dos pais, jogos livres, TV, artesanato e brinquedos e também criação de imagens positivas para melhorar o humor da criança. Ainda, de acordo com este estudo, as crianças no jardim de infância expressaram mais estratégias de enfrentamento do que as crianças doentes. Os resultados mostraram que, além das estratégias tradicionais que as crianças usam para aliviar o medo, a partir de suas emoções e cognições, é importante que elas tenham um papel ativo, com a sensação de controle sobre a situação e oportunidade de participar do seu tratamento.

Quando o indivíduo com FLP entra na fase da adolescência, além das complexas modificações que o acometem, do acelerado crescimento físico e desenvolvimento psicossocial, existem também os problemas funcionais, estéticos e psíquicos que a anomalia acarreta. Os problemas funcionais mais comumente são relacionados à deglutição, 
mastigação, audição, respiração, comprometimento da arcada dentária e, quando o palato é acometido, pode apresentar uma voz nasalizada (Souza-Freitas, 1974).

De acordo com o Estatuto da Criança e do Adolescente (Brasil, 1990), considera-se criança a pessoa até 12 anos de idade incompletos e, adolescente, aquela entre 12 e 18 anos de idade.

Apesar desta tentativa de enquadrar o período da adolescência, é válido ressaltar o conceito de assincronia de maturação. Eisenstein (1999) menciona que o quesito mais usado para classificar a adolescência é a idade cronológica, mas é necessário levar em consideração a variabilidade e a diversidade dos parâmetros biológicos e psicossociais que ocorrem nesta época. Portanto, este não é o melhor critério descritivo para estudos clínicos, antropológicos ou populacionais.

De acordo com Aberastury e Knobel (1981), no período da adolescência ocorre o aparecimento das características sexuais secundárias que evoluem até a total maturação sexual. O indivíduo passa por um processo psicológico e de identificação que o transforma do ser criança à sua caracterização como adulto. A fase de dependência social e econômica se transforma gradativamente, dando início à independência.

São muitas as tarefas exigidas do indivíduo como a aceitação da imagem corporal modificada, de novos valores e estilos de vida, a independência dos pais e a elaboração de identidade própria (Gejer, Françoso e Reato 2001).

A adolescência é um momento de turbulência para muitos jovens, que traz questões socias, de independência e de identidade própria. Relacionamentos com os adultos e os pais são redefinidos e o adolescente procura estabelecer uma autocrítica que é separar-se da família de origem. Os valores dos amigos são comparados com os dos familiares; a escolha dos amigos, muitas vezes, ocorre de acordo com aqueles ensinados pela família, sendo que o fracasso ou sucesso pessoal pode depender do status no grupo social (Kapp-Simon, 1995).

Maas (2006) enfatiza que o projeto de vida criado nas fases anteriores se fortalece e se consolida na adolescência; o adolescente tem sonhos e busca a sua realização e, nessa fase, precisa do reconhecimento de seu valor, confiança e aprovação. A transição de saúde-doença com doença crônica de adolescentes hospitalizados, com idades entre 10 e 19 anos, foi objeto de estudo desse autor, com o objetivo de compreender as significações expressas e sua relação com a equipe de enfermagem. Os resultados indicaram que a hospitalização pode causar 
angústias, o adolescente precisa adaptar-se à situação e os profissionais da enfermagem devem ser sensíveis às necessidades do adolescente, contribuindo para a sua adaptação durante a hospitalização.

Em se tratando de adolescentes com uma desfiguração visível, seja ela congênita ou adquirida durante sua vida, podem sofrer um profundo impacto psicológico, com dificuldades que incluem os efeitos adversos na imagem corporal, qualidade de vida e autoestima. Além disso, encontros sociais podem apresentar muitos desafios, porém muitas pessoas se adaptam às exigências colocadas em sobre elas e parecem relativamente pouco afetadas pela sua diferença (Rumsey e Harcourt, 2004).

$\mathrm{Na}$ fase da adolescência, o fato de o indivíduo ter nascido com fissura de lábio ou palato pode complicar ainda mais as atividades deles exigidas. Cabe a eles a decisão sobre permitir ou não que a diferença facial interfira nos relacionamentos sociais, incluindo relações de namoro, durante os anos do ensino médio. O adolescente tem, em geral, autoconsciência da sua aparência; mas, quando são diferenças faciais visíveis, o nível de autoconsciência pode se intensificar (Rumsey e Harcourt, 2004).

As cirurgias corretivas podem ser desejadas o mais precocemente possível, mas também podem ser temidas em virtude da atenção adicional que provocariam sobre o adolescente, da interferência nas atividades que realizam como esportes e empregos. As decisões sobre as cirurgias criam tensões adicionais e pode haver discordância entre adolescentes, pais e profissionais, sobre as prioridades cirúrgicas (Kapp-Simon, 2004).

Segundo Turner et al (1997), os pais e filhos de 15 anos de idade apresentavam diferentes satisfações frente às características faciais. Os pais relatavam uma maior satisfação com os resultados e as áreas que apresentavam uma maior diferença de percepções foram os lábios e dentes. Tal desacordo entre pais e filhos levanta a questão de quem deveria controlar a tomada de decisão para a realização de cirurgias adicionais.

Para ajudar as famílias a resolverem os diferentes pontos de vista entre pais e adolescentes, a respeito do tratamento adicional, Kapp-Simon (1995) defendeu o uso de um modelo de auto-compreensão (Kapp-Simon, 1991). Dessa forma, pais e adolescentes identificam se devem ou não realizar as cirurgias adicionais e, com uma comunicação aberta, incentivo e orientação da equipe médica, as famílias determinam as prioridades de tratamento, 
preservam a autoestima do adolescente e garantem que as cirurgias estão sendo programadas em comum acordo (Kapp-Simon, 2004).

Um estudo de Chetpakdeechit et al (2009) realizado com jovens com FLP ou fissura de palato isolada teve como objetivo compreender percepção, valores e como os tratamentos afetam a qualidade de vida. Os autores concluíram que os indivíduos queriam ser como todo mundo, sentiam-se diferentes dos outros por causa da fala comprometida e da aparência, o que interferia na autoestima, a qual pode ser influenciada pelo reconhecimento de pessoas significativas, fazendo com que se sintam iguais.

Outro estudo foi utilizado para determinar os efeitos psicossociais da fissura de lábio e ou palato entre crianças e adultos jovens, em comparação com um grupo controle sem fissura, com idades entre oito e 21 anos. Os resultados apresentaram que os participantes com fissura relataram maiores problemas comportamentais, mais sintomas de depressão e eram menos felizes com a sua aparência facial. Concluíram que a maioria das crianças e adultos não possui grandes problemas psicossociais, porém alguns problemas específicos podem surgir, tais como comportamentais, insatisfação com a aparência, depressão e ansiedade (Hunt et al, 2006).

Para avaliar os fatores que afetam a relação com a saúde e qualidade de vida das crianças e pré-adolescentes com fissuras orais não sindrômicas, Damiano et al (2007) realizaram um estudo para comparar se havia diferenças relacionadas com o tipo de fissura e outros fatores. As entrevistas com pais de crianças com idade entre dois e 12 anos com fissuras, mostraram que os casos com problemas menos graves de fala apresentaram maior qualidade de vida. Preocupações de fala e estética pareceram importantes e afetaram a qualidade de vida relacionada à saúde dessas crianças. Esses fatores pareceram mais importantes quando as crianças se aproximavam da adolescência, dos oito aos 12 anos, quando a aceitação pelos companheiros é mais crítica.

Foi desenvolvido um estudo com adultos suecos com FLP, comparados com adultos sem fissura, para avaliar a qualidade de vida em geral, bem-estar e saúde. Os resultados apontaram que o grupo com FLP avaliou sua qualidade de vida significativamente menor do que o grupo-controle nas áreas de sentido da vida, família e economia privada; não houve diferenças significativas entre os grupos em relação ao bem-estar. No grupo com FLP, a qualidade relacionada à saúde foi significativamente menor em relação à vida global, bemestar, contatos sociais e vida familiar; mas, foi significativamente maior em tempo de lazer e 
ser ativo. Os autores, Marcusson; Akerlind; Paulin (2001), concluíram que o grupo com FLP tinha um forte impacto da deficiência nas suas vidas sobre os aspectos globais, bem-estar e vida social, mas os aspectos relacionados a sua vida diária não foram afetados, e só alguns pequenos aspectos da sua qualidade de vida em geral eram pobres em comparação com o grupo-controle, o que indica um ajuste de vida razoavelmente bom.

Topolski; Edwards; Patrick (2005) compararam a qualidade de vida dos jovens com diferenças faciais visíveis, com jovens com algumas limitações, mas não com diferenças visíveis na face, como por exemplo déficit de atenção, hiperatividade, ou nenhuma diferença conhecida. Os participantes tinham idades entre 11 e 18 anos e os autores concluíram que os adolescentes com diferenças faciais enfrentaram desafios significativos à sua autoidentidade, enquanto o outro grupo experimentara maiores desafios nas relações, possivelmente a partir de sua necessidade de negociar e manter o apoio familiar próximo.

A estética, função e saúde da qualidade de vida de pacientes com FLP e idades entre 18 e 30 anos, já operados, foram avaliadas por cinco especialistas e pelos próprios sujeitos. Estes classificaram o resultado estético significativamente pior do que os especialistas e foi verificado que a cirurgia do lábio e do nariz parecia ser de grande importância para eles. Os resultados sugeriram que as expectativas dos pacientes não são realistas, a cirurgia deve ser realizada para melhorar a qualidade de vida, mas se os desejos deles não podem ser obtidos com este procedimento, eles devem ser aconselhados a realizar um acompanhamento psicológico (Sinko et al, 2005).

Além de todas essas implicações físicas e funcionais no que diz respeito às FLP, Pereira e Mota (1997) destacaram as questões psicossociais, pois a aparência física comprometida e a dificuldade na comunicação favorecem a discriminação do indivíduo no meio social.

Quando a pessoa com FLP chega à adolescência e não está satisfeita com o seu rosto, ela pode vir a ter vergonha da sua face e apresentar distúrbios psicológicos e os adultos jovens tendem a sentir mais dificuldade no relacionamento interpessoal. Dentre os problemas que podem surgir encontram-se frustração, depressão, irritabilidade fácil, diminuição da autoestima e isolamento social. Porém, dependendo da personalidade da pessoa e de como sua família aceita e lida com a malformação, a estabilidade emocional pode ser preservada (Ribeiro e Moreira, 2005). 
Moraes (2007) obteve relatos de familiares de crianças com FLP, indicando que a maioria dos casos entre 11 e 12 anos enfrentou dificuldade em participar de atividades recreativas durante a hospitalização. As dificuldades foram relacionadas à faixa etária, início da adolescência e à exigência com a aparência física. Segundo os familiares, as crianças não queriam lembrar que nasceram com FLP e, quando se deparavam com outras nas mesmas condições, se retraíam. Também mencionaram que, na hospitalização, começavam a se preocupar com a aparência física e não queriam se expor, devido aos pontos cirúrgicos, hematomas e edemas.

De acordo com Lévinas (1993), a expressão que o rosto introduz no mundo transpassa a forma que o delimita e, no sentido estético e psicológico, exerce uma influência infinita. Assim, a pessoa com malformação pode apresentar problemas emocionais quando comparada às pessoas "normais", uma vez que a malformação e o ajuste psicossocial estão associados em virtude de sentimentos negativos que acarretam nas pessoas afetadas, como ansiedade e fobia social.

A grande influência da aparência facial nos ambientes sociais frequentados intervém no contato social, no desenvolvimento da personalidade e no desempenho educacional. Um suporte se faz necessário ao longo do crescimento e desenvolvimento e, também, durante o longo processo de reabilitação da pessoa com malformação (Lockhart, 2003 e Kapp-Simon 2004, 2006).

A reabilitação do indivíduo com FLP requer um tratamento especializado que tem início ao nascimento e dura em média 20 anos, gerando várias situações de hospitalização. A hospitalização, por sua vez, leva a sentimentos de dependência, inferioridade e insegurança, associado ao medo do desconhecido, dos instrumentos e aparelhos hospitalares (Almeida, Rodrigues e Simões 2005).

O adolescente durante a hospitalização, de acordo com Armond (1996), sofre uma regressão em seu desenvolvimento cognitivo e afetivo e, quando se interna, manifesta sua fragilidade emocional por meio de reações de negação, fantasias e da necessidade da presença materna ou do familiar mais próximo.

Almeida; Rodrigues; Simões (2005) relataram que os adolescentes devem ser vistos como um grupo importante, que necessita de cuidado em unidade especializada. Mas ainda não se encontra, na maioria dos hospitais, áreas de internação específicas e nem infraestrutura 
física para receber esse jovem, que é hospitalizado em enfermaria pediátrica ou de adulto, acarretando dificuldades maiores de aceitação por não se adaptarem a esses cenários.

A população em geral apresenta preocupação com a aparência física e a maioria das pessoas procura maneiras de modificar essa aparência com a intenção de melhorar a forma de se ver e de ser aceito pelos demais. Além disso, existe uma exigência da sociedade em busca da perfeição e do belo, sendo bem provável que as pessoas com malformação tenham uma preocupação mais exacerbada (Rumsey e Harcout, 2004).

Para Monlleó (2004), a pessoa com malformação se depara com situações de enfrentamento da estigmatização e de exclusão social relacionada aos aspectos profissionais e educacionais. O rosto é uma fonte de sentidos, de acordo com Lévinas (1980) que, em seus estudos, identificou que as pessoas com malformação apresentam baixa autoestima, dentre outras alterações emocionais, e isto reflete no desenvolvimento da sua personalidade e no seu relacionamento no meio social.

Segundo Bastos; Gardenal; Bogo, (2008) a aparência da face representa grande influência no meio social das pessoas com malformação craniofacial e interfere no desenvolvimento educacional e da personalidade. Os autores defendem uma atenção maior a essa clientela, principalmente às crianças e adolescentes, ou seja, um apoio psicossocial que é de grande importância durante o processo de reabilitação.

Oosterkamp et al (2007) realizaram um estudo para avaliar a satisfação com a aparência facial relacionada com a saúde e qualidade de vida nos pacientes com fissura labial bilateral e palatina. Foram sujeitos 43 adultos tratados de FLP com idade média de 28,2 anos e grupo-controle pareados por idade, sexo e nível socioeconômico. A avaliação quantitativa e qualitativa revelou que os pacientes com FLP ficaram significativamente menos satisfeitos com a aparência do lábio superior, nariz e respiração nasal. Além disso, a satisfação com a aparência facial foi positivamente correlacionada com o grupo-controle. Para fala e audição, os pacientes com FLP tiveram problemas consideráveis e preocupações com essas funções. Esse estudo apontou a importância da avaliação qualitativa de satisfação do paciente com o resultado do tratamento, para identificar problemas e preocupações individuais.

No HRAC/USP, durante todo o complexo tratamento e as inúmeras hospitalizações, a pessoa com FLP tem o acompanhamento das equipes médica, odontológica, fonoaudiológica 
e das áreas de apoio como terapia ocupacional, fisioterapia, nutrição, psicologia, enfermagem, serviço social e genética (Universidade de São Paulo, 2008).

Os resultados de Moraes; Buffa; Motti (2009), em estudo conduzido com familiares de pacientes internados para realizar cirurgias eletivas, indicaram que a maioria dos familiares que brincaram com a criança durante o pré-operatório, apontou melhora no seu estado emocional. O estudo mostrou a importância de verificar, junto aos adolescentes e jovens adultos que ainda estão em tratamento no HRAC/USP, a contribuição das atividades expressivas e recreativas desenvolvidas durante a hospitalização, nos demais ambientes sociais onde convivem.

\subsection{Atividades expressivas e recreativas na hospitalização da pessoa com FLP no HRAC/USP}

No HRAC/USP os pacientes não ficam no leito e são encaminhados ao Serviço de Educação e Terapia Ocupacional (SETO) onde são desenvolvidos trabalhos relacionados às atividades expressivas e recreativas, dentre as quais: expressão dramática, expressão corporal e musical, e expressão plástica, direcionadas às diferentes faixas etárias (Moraes, 2007). Mas, será que essas atividades, que são desenvolvidas durante as internações para os procedimentos de reabilitação, colaboram para facilitar a vida familiar, social, afetiva, escolar e ocupacional dos adolescentes e jovens adultos com FLP?

É importante destacar que, durante o longo tratamento do paciente com FLP no HRAC/USP, pontuado por várias cirurgias, o SETO também conhecido com o antigo nome de Recreação, é o local onde os pacientes e seus familiares são acolhidos e envolvidos nas atividades expressivas e recreativas. Nas diversas fases da vida os pacientes vivenciam experiências nesse local, que tornam o ambiente familiar e de referência para suas internações, o que constrói e fortalece vínculos com funcionários, familiares e com outros pacientes em tratamento (Moraes, 2007).

Este trabalho junto aos pacientes teve início em 1974, anterior aos atuais conceitos de humanização, com a preocupação de oferecer um ambiente favorável à reabilitação, proporcionando bem-estar aos casos atendidos no HRAC/USP. Muitas mudanças ocorreram e se consolidaram com o passar do tempo, tanto nos protocolos terapêuticos, quanto nas 
técnicas aplicadas nas intervenções, mas a filosofia de humanização continuou (Moraes, 2007).

$\mathrm{Na}$ Recreação ficam os pacientes e acompanhantes em processo pré e pós-cirúrgico. $\mathrm{O}$ local é dividido por salas: Brinquedoteca para crianças até os 12 anos em condição précirúrgica e pós-cirúrgica e acompanhantes; Sala de Expressão Dramática para adolescentes e adultos em condição pré e pós-cirúrgica e seus acompanhantes; Sala de Espera Cirúrgica para acompanhantes dos pacientes que estão em cirurgia (Moraes, 2007).

Nessas salas são disponibilizadas diversas atividades expressivas e recreativas, observando a faixa-etária, a condição clínica, a dinâmica do grupo, mas buscando sempre favorecer a recuperação do paciente, bem-estar e integração social. As atividades são: Expressão Corporal e Musical (dança, videokê, mímica, show musical, alongamento, entre outras); Expressão Dramática (teatro de fantoches, dramatização de histórias, teatro de palco, entre outras); Expressão Plástica (técnicas de pintura, recorte, colagem, modelagens, trabalho com materiais reaproveitáveis, confecção de jogos e brinquedos); atividades artesanais em geral (costura, pintura, bordados, entre outros), confecção de brinquedos, jogos e objetos com materiais reaproveitáveis, leituras de livros, revistas, jornais, textos e panfletos informativos, livros de receitas culinárias (específicas da região de origem), livro de depoimentos de pais, apresentações de vídeos sobre o Hospital, Dinâmicas de Grupo (técnicas de integração, descontração e relaxamento), Recreação (jogos e brinquedos em geral), assim como atendimento pedagógico, caso a criança necessite de uma internação longa (Moraes, 2007).

As atividades expressivas (plástica, pintura, desenho, teatro, dança, entre outras) desenvolvidas com pacientes e familiares, não são realizadas com a intenção de torná-los dançarinos ou artistas; mas, de acordo com Saraceno (1999), com o objetivo de favorecer ações comunitárias, que atinjam as relações familiares e sociais, promovendo a integração independentemente das condições socioeconômicas e culturais.

As atividades artísticas, segundo Angerami-Camon (1988) sobre os benefícios terapêuticos acarretados, auxiliam na reorganização dos sentimentos. A pintura favorece a expressão de afetos e emoções muitas vezes revelados na escolha das cores, proporcionando a sensação do poder criativo (Oaklander, 1980). A leitura pode ser trabalhada com diversos temas e recursos, tais como fantoches e adereços. Para Balestriero (1998), na prática de recitar poesias são usados jogos de linguagem e jogos poéticos, por isto este instrumento usado nos 
hospitais pode ser um recurso educacional. A modelagem exige a técnica de energia adequada, a criança sente-se feliz com a manipulação pela sensação de posse e do poder de transformação atuando nas sensações físicas (estruturação e coordenação motora) e viscerais (sentimentos e sensações primitivas).

A prática da música proporciona um momento de descontração e motivação, que pode ser individual ou em grupo, favorecendo a liberdade de expressão, concentração e autoestima. Para Gainza (1998), a música é capaz de produzir uma sensação de relaxamento e auxilia no processo de reabilitação.

Liberman (2010) também retratou que as atividades corporais auxiliam na compreensão do sujeito a partir de um olhar que privilegia o corpo e suas potencialidades, e ainda, que essas atividades podem ser oportunidades e experiências para a construção de outros caminhos no processo de reabilitação. A expressão corporal, de acordo com Porto (2008), é uma conduta espontânea preexistente, pois é uma linguagem do corpo. Trabalhar esta linguagem permite compartilhar com o outro o que se pensa e sente, e algumas práticas são voltadas para o desenvolvimento, recuperação ou o resgate do próprio corpo, buscando a integração dos aspectos corporal, mental e afetivo.

O trabalho com linguagens do corpo é rico em possibilidades na prática terapêutica. A experimentação de uma coreografia, de uma postura corporal, de brincar com o próprio corpo, de modificar e recriar outras maneiras de incorporar a arte contribui para melhorar as potencialidades da vida. É possível, assim, repensar o sujeito como alguém que busca o autoconhecimento, como cidadão, transformador e questionador da sociedade (Liberman, 2002).

Segundo Sponton; Guarita; Teixeira (2007) a arte pode ser utilizada como meio de expressão e comunicação. Um trabalho desenvolvido por meio das quatro linguagens artísticas (artes plásticas, literatura, música e teatro) oferece aos envolvidos um ambiente em que a imaginação e a criatividade possibilitam novas maneiras na busca de soluções, deixando-os seguros para vivenciar e também experimentar algo pronto ou algo a ser criado. A arte media o diálogo entre o ser humano e a sua realidade, proporciona novas formas de pensamento e de conceitos significativos, melhora a percepção e favorece o envolvimento social, emocional e afetivo. 
Em um projeto envolvendo observação, avaliação e levantamento de dados, Sponton; Guarita; Teixeira, (2007) defenderam a importância das atividades expressivas para o processo de reabilitação e iniciaram um projeto de atividades grupais e de interação. Consideraram que a hospitalização pode prejudicar o desenvolvimento social, cognitivo, emocional e afetivo da criança ou adolescente, provocando sentimentos de ansiedade, depressão, medo e angústia.

Estudo realizado por Garcia et al (2011) descreveu a atuação da Terapia Ocupacional junto a adolescentes hospitalizados, usando como recursos jogos, atividades lúdicas, artesanais e expressivas. Os dados mostraram, como principais objetivos dos atendimentos, estabelecer vínculo terapêutico; auxiliar no enfrentamento da hospitalização e do adoecimento; favorecer o desempenho das atividades de vida diária (AVD), participação social, lazer, educação e trabalho; estimular a descoberta de novas habilidades e capacidades; orientar quanto à realização de exames, procedimentos e acolher adolescentes e cuidadores. Apesar da resistência inicial dos adolescentes, típica da faixa-etária, ao longo dos atendimentos os pacientes foram adquirindo maior autonomia e passando a se comunicar mais. Concluíram que uma intervenção adequada pode minimizar os impactos negativos na trajetória desses sujeitos, aumentando as chances de adesão ao tratamento e retorno a uma vida normal.

Carney et al (2003) realizaram uma pesquisa com crianças e adolescentes com idades entre 4 e 17 anos que estavam em enfermarias pediátricas, levantando temas de interesse. Os procedimentos, principal ponto de discussão, já que hospitalização estava centrada no tratamento, foram mencionados por menos da metade das crianças, enquanto o ambiente hospitalar foi mencionado por mais da metade delas, abrangendo adolescentes e crianças mais velhas. As crianças menores comentaram sobre comida, TV, vídeo, jogos, o que podia estar relacionado à continuidade da experiência hospitalar com seu ambiente normal. Quase metade dos participantes fizeram comentários positivos relativos à interação no hospital e apenas $16,9 \%$ relataram sentir-se ansiosos. A ansiedade foi mencionada principalmente sobre a vinda ao hospital, sendo que, após a internação, eles estavam confortáveis. Os resultados mostraram que os adolescentes se preocupavam com o ambiente físico do hospital como tema importante, sendo, portanto, necessário adequar as instalações para eles. 
A adolescência é uma fase da vida repleta de transformações que exigem respostas do indivíduo aceitando a nova condição e preparando-se para a maturidade, e a FLP traz implicações que influenciam diretamente a estética e as relações sociais. Assim informações que possam ser aplicadas e venham auxiliar a reabilitação dos pacientes dessa fase são de grande utilidade.

São necessários conhecimentos a respeito da percepção dos pacientes sobre as atividades expressivas e recreativas, bem como sobre a contribuição desse tipo de abordagem durante a hospitalização na vida familiar, social, afetiva, escolar e ocupacional. Tais conhecimentos ainda são indisponíveis, motivando a realização deste trabalho, com a finalidade de contribuir tanto para o processo de reabilitação quanto para a inserção social e familiar desse paciente adolescente e adulto jovem com FLP.

Em virtude de não haver nenhum estudo prévio específico sobre o tema e diante da escassez na literatura a respeito de atividades expressivas e recreativas desenvolvidas com adolescentes e jovens adultos com FLP durante a hospitalização, e a contribuição destas atividades para o paciente no meio social, verificou-se a importância de realizar um estudo com esta clientela no HRAC/USP. 
3 Ojetivo 



\section{OBJETIVO}

O objetivo deste estudo foi investigar, junto aos adolescentes e jovens adultos com FLP transforame incisiva que foram submetidos a cirurgias e internações no HRAC/USP e participaram de atividades expressivas e recreativas durante os períodos de hospitalização, a contribuição dessas atividades na sua vida familiar, social, afetiva, escolar e ocupacional. 



\section{Materiale}

Método 



\section{MATERIAL E MÉTODO}

O projeto de pesquisa foi aprovado pelo Comitê de Ética em Pesquisa (CEP) do HRAC/USP, em 05/03/2010 (Anexo 1).

\subsection{Sujeitos}

Participaram deste estudo 53 pessoas com fissura transforame incisiva unilateral ou bilateral, com idades entre 14 e 23 anos (Anexo 2), selecionadas dentre os pacientes que compareceram para atendimentos no HRAC/USP no período da pesquisa.

O serviço de informática previamente emitiu relatório dos pacientes agendados, que atendiam os critérios de seleção: tipo de fissura transforame, faixa etária, procedentes da região sudeste, inexistência de outras malformações que pudessem interferir no seu desenvolvimento e relacionamento social, haviam sido submetidos a três ou mais cirurgias no Hospital, sendo a última no período de 2005 a 2009.

De acordo com este levantamento, a pesquisadora solicitou o agendamento destes pacientes para o atendimento de Terapia Ocupacional, além dos procedimentos com as demais áreas. No atendimento com a pesquisadora, esta os convidava a participar da pesquisa..

Dentre as dificuldades encontradas, uma delas foi conseguir o agendamento dos pacientes, nos casos em que os horários já estavam completos.

A fissura transforame foi escolhida por ser considerada complexa e afetar os aspectos estéticos e funcionais, exigindo um maior número de internações e intervenções cirúrgicas. A faixa etária envolvendo adolescentes e jovens adultos foi definida, com base no roteiro de Etapas e Condutas Terapêuticas do HRAC/USP (Universidade se São Paulo, 2008), segundo o qual aos 14 anos de idade o paciente já realizou as cirurgias primárias e aos 23 anos já está no final do tratamento.

A adolescência é uma fase de muitas e rápidas mudanças físicas e comportamentais, durante a qual a pessoa constrói a sua identidade e define a sua personalidade, passa por uma crise e reformula os valores adquiridos na infância, abrindo espaço para uma estrutura mais 
madura Nessa etapa da vida desponta uma grande exigência com relação à imagem corporal, independência e elaboração de identidade. Até os 23 anos, o jovem adulto ainda se encontra em uma fase de definições e expectativas com relação à sua vida social, emocional, relacionamentos, à escolaridade e entrada no mercado de trabalho (Aberastury e Knobel, 1981e Minervino-Pereira, 2005). Além desses critérios, considerou-se a não existência de outras malformações que poderiam influenciar os resultados, caso interferissem no processo de desenvolvimento e nos relacionamentos sociais. A limitação da procedência dos sujeitos à região sudeste visou homogeneizar as condições sociodemográficas e evitar dificuldade de acesso ao tratamento. $\mathrm{O}$ critério de pelo menos três cirurgias foi estabelecido para garantir que o paciente tivesse tido oportunidade de participar das atividades expressivas e recreativas oferecidas durante a hospitalização.

Não houve preocupação quanto ao sexo dos participantes, ao nível escolar ou a situação social e econômica.

\subsection{Procedimentos}

A entrevista foi escolhida para coleta de dados, por ser uma técnica que possibilita o relacionamento mais próximo entre o entrevistado e o entrevistador e permitir conhecer as informações que as pessoas detêm, se as compreendem, como as compreendem, bem como opiniões e sentimentos que experimentam (Marconi e Lakatos, 2003 e Turato, 2003).

As entrevistas foram realizadas de março a dezembro de 2010, no Serviço de Educação e Terapia Ocupacional (SETO) do HRAC/USP, em local que garantiu privacidade.

Um roteiro semiestruturado (Anexo 3) foi utilizado como instrumento de coleta de dados, com a intenção de conhecer mais profundamente as vivências e experiências de vida do entrevistado (Turato, 2005). O instrumento em forma de perguntas favorece a obtenção de dados de acordo com o ponto de vista dos pesquisados. Questões simples, que oferecem alternativas ou sob a forma de perguntas abertas, possibilitam respostas livres com as próprias palavras do entrevistado e tendem a limitar erros de compreensão, que comumente prejudicam as interpretações (Correia et al 1985, Gil 1991, Tavano 2000, Marconi e Lakatos 2003 e Turato 2003). 
O roteiro foi especialmente elaborado pela pesquisadora, por se tratar de uma investigação sobre aspectos não encontrados em protocolos já validados. Contemplou dados de identificação que foram levantados nos prontuários clínicos, perguntas abertas e outras oferecendo alternativas, abordando as questões relevantes à pesquisa. Estas questões versavam sobre as atividades expressivas e recreativas oferecidas aos pacientes durante suas hospitalizações, procurando investigar em quais participaram, quais consideraram mais marcantes e quais trouxeram alguma contribuição para sua vida nos aspectos familiar, social, afetivo, escolar e ocupacional. Esse roteiro de entrevistas foi previamente testado em 10 pacientes e considerado adequado aos objetivos do trabalho.

No primeiro contato com o participante, acompanhado do responsável quando menor de 18 anos, era esclarecida a sua liberdade de participação na pesquisa, sem comprometimento do tratamento. Também foi garantida a privacidade e o sigilo das informações e identidade e, após a concordância, era assinado o Termo de Consentimento Livre e Esclarecido (Anexo 4), pelo paciente ou pelo responsável pelo menor.

A pesquisadora procurou estabelecer com o entrevistado uma situação de conforto, segurança e tranquilidade, sendo as entrevistas realizadas individualmente e o responsável pelo menor de 18 anos convidado a permanecer durante o procedimento. Mas todos os responsáveis optaram por deixar o paciente sozinho com a pesquisadora, para que tivessem mais privacidade.

As entrevistas foram gravadas com auxílio do Programa Sony Sound Forge, instalado em um microcomputador, o que permitiu que a pesquisadora ficasse atenta ao entrevistado e registrasse as suas observações.

Cada entrevista durou em média 30 minutos e depois foi transcrita e digitada na íntegra, quanto às falas e observações sobre comportamentos (sorriso, choro, etc.). A maior dificuldade encontrada pela pesquisadora durante a transcrição foi a compreensão da fala do entrevistado; pois, durante a entrevista, a expressão facial e a leitura labial facilitavam a compreensão, mas depois, somente o áudio dificultou o entendimento.

A transcrição de cada entrevista levou em média 4 horas. Essa demanda de grande período de tempo e a trabalhosa tarefa de transcrever e analisar dados de entrevistas são destacados por Neves (1996), dentre outros autores. 


\subsection{Análise dos dados}

As perguntas e respostas transcritas das entrevistas foram transferidas para planilhas, possibilitando tabulação dos dados de identificação e das questões com alternativas. As respostas às questões abertas foram submetidas à análise de conteúdo das falas dos entrevistados de acordo com Bardin (2008), que estabelece as seguintes etapas: pré-análise para organização e reconhecimento das ideias, estudo para categorização e tratamento dos resultados, inferência e interpretação. Mediante leituras sucessivas foram identificados temas e, quando possível, realizada a quantificação e análise.

Assim, as respostas obtidas foram analisadas quantitativa e qualitativamente, tipos de dados que se complementam segundo Minayo (1999), utilizando-se métodos descritivos absolutos e relativos. A análise qualitativa de acordo com Turato (2003) é muito interessante para profissionais da área da saúde em virtude da sua experiência em assistência. É uma prática que permite a realização de valiosos levantamentos de dados e interpretações dos resultados com bastante conhecimento sobre o assunto. Além disso, permite conhecer mais profundamente as vivências e as experiências de vida do entrevistado, possibilita o contato direto com o sujeito da pesquisa e oferece uma perspectiva diferenciada para a compreensão da realidade (Turato, 2005). 
5 Resultadose

Discussãa 



\section{RESULTADOS E DISCUSSÃO}

Os resultados foram organizados para apresentação, inicialmente com informações que caracterizam os sujeitos entrevistados, sua situação familiar, escolar e ocupacional, suas atividades e relacionamentos sociais, abrangendo ainda religião, esporte e lazer. Na sequência, dados sobre o tratamento e a participação nas atividades expressivas e recreativas durante as hospitalizações. Do contexto extra-hospitalar são apresentadas as opiniões dos entrevistados a respeito da convivência na família, escola e trabalho, com colegas, conhecidos em geral e com pessoas do sexo oposto. Finalmente, as respostas dos entrevistados ao avaliarem seu estágio de reabilitação e a contribuição das atividades expressivas e recreativas para suas vidas.

\subsection{Caracterização dos sujeitos entrevistados}

Foram entrevistadas 53 pessoas com fissura transforame incisiva, sendo $35(66,04 \%)$ do tipo unilateral e $18(33,96 \%)$ bilateral, $37(69,81 \%)$ homens e $16(30,19 \%)$ mulheres, com idades entre 14 e 23 anos. A Tabela 1 abaixo apresenta a distribuição dos sujeitos por faixa etária e sexo.

Tabela 1 - Sujeitos entrevistados, de acordo com a faixa etária e o sexo.

\begin{tabular}{lcccccc}
\hline \multirow{2}{*}{ Faixa etária em anos } & \multicolumn{3}{c}{ Feminino } & \multicolumn{2}{c}{ Masculino } & \multicolumn{2}{c}{ Total } \\
& $\mathbf{N}$ & $\mathbf{\%}$ & $\mathbf{N}$ & $\mathbf{\%}$ & & $\%$ \\
\hline 14 a 16 & 3 & 5,66 & 6 & 11,32 & $\mathbf{9}$ & $\mathbf{1 6 , 9 8}$ \\
17 a 19 & 8 & 15,09 & 12 & 22,64 & $\mathbf{2 0}$ & $\mathbf{3 7 , 7 4}$ \\
20 a 23 & 5 & 9,43 & 19 & 35,85 & $\mathbf{2 4}$ & $\mathbf{4 5 , 2 8}$ \\
Total & $\mathbf{1 6}$ & $\mathbf{3 0 , 1 9}$ & $\mathbf{3 7}$ & $\mathbf{6 9 , 8 1}$ & $\mathbf{5 3}$ & $\mathbf{1 0 0 , 0 0}$ \\
\hline
\end{tabular}

Conforme apresentado na Tabela 1, os entrevistados foram divididos em três faixas etárias, para fins de apresentação e análise. Serviu de critério para estabelecer as faixas etárias, o período da adolescência, em que ocorrem grandes aquisições e mudanças na vida do indivíduo, caracterizado de acordo com o Estatuto da Criança e do Adolescente (Brasil, 1990) dos 12 aos 18 anos de idade. Considerou-se, ainda, a possibilidade legal de trabalho na condição de aprendiz, dos adolescentes de 14 a 16 anos (Brasil, 2000) e a regulamentação do 
ensino fundamental em nove anos, o qual se estenderia até os 14 anos de idade (Brasil, 2006), permitindo cursar e concluir o ensino médio a partir dos 17 anos. Dos 20 aos 23 anos é estimado que o indivíduo alcance a fase adulta, inicie o ensino superior e entre para o mercado de trabalho.

Os resultados encontrados mostraram que os sujeitos selecionados para a amostra apresentaram coerência com a literatura no caso da maior incidência da FLP no sexo masculino, bem como com a maior frequência, no caso das fissuras transforame, para o comprometimento unilateral (Frase 1970, Greene et al 1964, Greene 1968, Abyholm 1978 Capelloza Filho 1988, Modolin e Cerqueira 1997 e Dixon et al 2011).

Os sujeitos entrevistados procediam da região sudeste do Brasil, em sua maioria do estado de São Paulo (73,58\%), justificado em virtude do HRAC/USP se localizar neste estado, o que proporciona facilidade de acesso. Os demais entrevistados eram 20,75\% provenientes de Minas Gerais, 3,77\% do Espírito Santo e 1,89\% do Rio de Janeiro.

Em relação à condição social e econômica, as informações levantadas nos prontuários mostraram que a grande maioria dos entrevistados pertencia aos extratos baixo superior $(73,58 \%)$ ou inferior $(11,32 \%)$, enquanto $15,09 \%$ pertenciam ao extrato médio inferior. É utilizada no HRAC/USP uma organização de indicadores para a avaliação socioeconômica desenvolvida por Graciano; Lehfeld; Neves Filho (1996, 1999), compreendendo: situação econômica da família, número de membros, ocupação, habitação e escolaridades. Essas informações são reunidas em uma tabela com seis estratificações: Baixa Inferior (BI), Baixa Superior (BS), Média Inferior (MI), Média (M), Média Superior (MS) e Alta (A).

Os dados encontrados na avaliação dos entrevistados refletem a realidade do HRAC/USP bem como a realidade brasileira, considerando, de acordo com Benjamin (1997), o nível de desigualdade social da população brasileira que acontece em virtude da grande concentração de renda do país em apenas $1 \%$ da população.

A respeito da situação familiar dos entrevistados, as respostas quanto às pessoas com quem moravam indicaram que a maioria $(86,79 \%)$ residia com a família, incluindo o pai ou a mãe, além de outros parentes. Os demais: 3 (5,66\%) moravam com amigos, outros $3(5,66 \%)$ moravam respectivamente com a esposa, irmãos e tios; e um informou que morava sozinho. Nenhum paciente tinha filhos e o único que morava com esposa informou que ela estava grávida. 
Quanto ao número de irmãos, 5 (9,43\%) entrevistados eram filhos únicos. No geral, a maioria, $32(60,37 \%)$, tinha um ou dois irmãos, $12(22,64 \%)$ tinham de três a cinco irmãos e 4 $(7,54 \%)$ tinham de seis a oito irmãos. Dentre os 53 entrevistados, 7 (13,21\%) tinham irmãos que também apresentavam FLP, sendo que em um (1,89\%) caso não se tratava de irmão biológico.

As informações a respeito do grau de escolaridade dos pais e mães dos entrevistados também foram levantadas para se conhecer o meio sociocultural dos sujeitos da pesquisa. A Tabela 2 revela que a maior parte $28(26,42 \%)$ tinha Ensino Fundamental Incompleto, seguida do Ensino Médio Completo 27 (25,47\%).

Tabela 2 - Pais e mães dos sujeitos entrevistados, de acordo com nível de escolaridade.

\begin{tabular}{lcccccc}
\hline \multirow{2}{*}{ Grau de escolaridade } & \multicolumn{2}{c}{ Pai } & \multicolumn{2}{c}{ Mãe } & \multicolumn{2}{c}{ Total } \\
& N & \% & N & \% & N & \% \\
\hline Ensino Fundamental Incompleto & 11 & 20,75 & 17 & 32,08 & $\mathbf{2 8}$ & $\mathbf{2 6 , 4 2}$ \\
Ensino Fundamental completo & 10 & 18,87 & 5 & 9,43 & $\mathbf{1 5}$ & $\mathbf{1 4 , 1 5}$ \\
Ensino Médio incompleto & 2 & 3,77 & 2 & 3,77 & $\mathbf{4}$ & $\mathbf{3 , 7 7}$ \\
Ensino Médio completo & 11 & 20,75 & 16 & 30,19 & $\mathbf{2 7}$ & $\mathbf{2 5 , 4 7}$ \\
Ensino Superior incompleto & 1 & 1,89 & 1 & 1,89 & $\mathbf{2}$ & $\mathbf{1 , 8 9}$ \\
Ensino Superior completo & 8 & 15,09 & 8 & 15,09 & $\mathbf{1 6}$ & $\mathbf{1 5 , 0 9}$ \\
Não souberam informar & 10 & 18,87 & 4 & 7,55 & $\mathbf{1 4}$ & $\mathbf{1 3 , 2 1}$ \\
Total & $\mathbf{5 3}$ & $\mathbf{1 0 0 , 0 0}$ & $\mathbf{5 3}$ & $\mathbf{1 0 0 , 0 0}$ & $\mathbf{1 0 6}$ & $\mathbf{1 0 0 , 0 0}$ \\
\hline
\end{tabular}

A família tem o status de agente formador e influenciador do sujeito e busca estratégias de adaptação a cada nova fase do desenvolvimento, para que ocorram reestruturações. É o primeiro grupo a que pertence o indivíduo, onde são estabelecidas as primeiras relações afetivas, treino de funções e papéis sociais (Pinho e Kantorski, 2004 e Minervino-Pereira 2005).

As famílias dos sujeitos entrevistados apresentavam um diversificado nível de escolaridade, mas tinham em comum o acesso às orientações dos profissionais da equipe de reabilitação do HRAC/USP, desde que seus filhos com FLP tinham poucos meses de vida (Universidade de São Paulo, 2008 e Freitas et al, 2012b).

Além da faixa etária dos entrevistados limitar-se aos 23 anos de idade, favorecendo que residissem com as famílias, esses dados ratificaram os estudos de Peter, Chinsky e Fisher (1975), Garcia, Neme e Chinelatto (1999) e Veronez (2007) ao afirmarem que as pessoas com 
FLP são consideradas emocionalmente dependentes dos seus familiares por mais tempo do que o jovem adulto da atualidade. Isto talvez se deva à confiança pelos cuidados e apoio recebidos, bem como pelo conforto que a família garante a eles, fornecendo uma base de segurança.

A situação escolar dos entrevistados foi identificada, conforme a Tabela 3 a seguir.

Tabela 3 - Sujeitos entrevistados, de acordo com acordo com a faixa etária e o nível de escolaridade.

\begin{tabular}{|c|c|c|c|c|c|}
\hline \multirow{2}{*}{ Escolaridade } & \multicolumn{3}{|c|}{ Faixa etária em anos } & \multirow{2}{*}{$\mathbf{N}$} & \multirow{2}{*}{$\%$} \\
\hline & $\begin{array}{c}14 \text { a } 16 \\
N\end{array}$ & $\begin{array}{c}17 \text { a } 19 \\
\mathbf{N}\end{array}$ & $\begin{array}{c}20 \text { a } 23 \\
\quad N\end{array}$ & & \\
\hline Ensino Fundamental incompleto & 2 & 2 & 1 & 5 & 9,43 \\
\hline Ensino Fundamental completo & 0 & 0 & 0 & $\mathbf{0}$ & $\mathbf{0 , 0 0}$ \\
\hline Ensino Médio incompleto & 7 & 7 & 5 & 19 & 35,85 \\
\hline Ensino Médio completo & 0 & 5 & 12 & 17 & 32,08 \\
\hline Ensino Superior incompleto & 0 & 6 & 5 & 11 & 20,75 \\
\hline Ensino Superior completo & 0 & 0 & 1 & 1 & 1,89 \\
\hline Total & 9 & 20 & 24 & 53 & 100,00 \\
\hline
\end{tabular}

Quanto ao nível de escolaridade dos entrevistados, conforme a Tabela 3, a maior parte tinha Ensino Médio Incompleto (35,85\%), seguido de 32,08\% com Ensino Médio Completo, $20,75 \%$ com Superior Incompleto e apenas um $(1,89 \%)$ entrevistado havia concluído o Ensino Superior.

A maioria dos entrevistados $(62,26 \%)$ continuava estudando, sendo 22 homens e 11 mulheres. Na faixa etária de 14 a 16 anos encontravam-se 9 (16,98\%) adolescentes que cursavam do $8^{\circ}$ Ano do Ensino Fundamental ao $2^{\circ}$ Ano do Ensino Médio. Os 15 (28,30\%) entrevistados dos 17 aos 19 anos se distribuíam entre o $9^{\circ}$ Ano do Ensino Fundamental e o Ensino Médio, incluindo $3(5,66 \%)$ que frequentavam cursinho preparatório para escola técnica (1) ou cursos técnicos (2). Dos 20 aos 23 anos, dos 9 (16,98\%) entrevistados, 3 $(5,66 \%)$ estavam em cursos técnico, profissionalizante ou preparatório para vestibular. Dentre os 13,21\% que haviam parado de estudar, 2 (3,77\%) não haviam completado o Ensino Médio, $4(7,55 \%)$ haviam completado e penas $1(1,89 \%)$ havia concluído o Ensino Superior.

Numa análise geral, cerca de 10 (18,87\%) sujeitos entrevistados estavam atrasados em relação ao nível escolar esperado para a idade, pois não haviam concluído o Ensino Fundamental e na faixa dos 20 a 23 anos, cinco não tinham concluído o Ensino Médio. Além 
disso, $20(37,74 \%)$ não estavam mais estudando. Dificuldades no desempenho escolar, às vezes criadas por questões de interação social negativa, estigmatização e exclusão social, podem surgir devido à aparência da face (Lévinas 1980, Lockhart 2003, Monlleó 2004, KappSimon 2004, 2006, Bastos, Gardenal e Bogo 2008). O apoio psicossocial durante o processo de reabilitação pode auxiliar a pessoa com FLP a enfrentar o meio e permanecer na escola.

Observou-se também que os sujeitos entrevistados informaram nível de escolaridade maior do que seus pais, ainda que 20 (37,74 \%) não estivessem estudando, o que pode indicar a percepção ou expectativa dos pais quanto à importância do estudo para uma condição profissional e financeira melhor para seus filhos.

Foi identificada a situação ocupacional dos entrevistados, caracterizada quando o indivíduo desenvolvia alguma espécie de trabalho remunerado. A maior parte dos entrevistados, 34 (64,15\%), exercia alguma atividade profissional, incluindo três que eram estagiários, sendo 25 homens e 9 mulheres. Ainda que a partir dos 14 anos o indivíduo possa iniciar a vida profissional como aprendiz (Brasil, 2000), esses sujeitos tinham idades de 18 a 23 anos. Conforme apresenta a Tabela 4.

Tabela 4 - Sujeitos entrevistados que trabalhavam, de acordo com a faixa etária e o sexo.

\begin{tabular}{lcrrrrrc}
\hline \multirow{2}{*}{ Faixa etária em anos } & \multicolumn{2}{c}{ Feminino } & \multicolumn{2}{c}{ Masculino } & \multicolumn{2}{c}{ Total } \\
& $\mathbf{N}$ & $\mathbf{\%}$ & $\mathbf{N}$ & $\mathbf{\%}$ & $\mathbf{N}=$ & $\mathbf{\%}$ \\
\hline 14 a 16 & 0 & 0,00 & 0 & 0,00 & $\mathbf{0}$ & $\mathbf{0}$ \\
17 a 19 & 4 & 11,76 & 8 & 23,53 & $\mathbf{1 2}$ & $\mathbf{3 5 , 2 9}$ \\
20 a 23 & 5 & 14,71 & 17 & 50,00 & $\mathbf{2 2}$ & $\mathbf{6 4 , 7 1}$ \\
Total & $\mathbf{9}$ & $\mathbf{2 6 , 4 7}$ & $\mathbf{2 5}$ & $\mathbf{7 3 , 5 3}$ & $\mathbf{3 4}$ & $\mathbf{1 0 0 , 0 0}$ \\
\hline
\end{tabular}

As ocupações informadas nas respostas dos entrevistados foram classificadas com base na Classificação Brasileira de Ocupações (CBO) do Ministério do Trabalho (Brasil, 1994). Apesar de existir uma atualização desse instrumento (Brasil, 2002), a CBO (Brasil 1994), de acordo com Graciano e Lehfeld (2010), atende melhor as necessidades específicas do HRAC/USP e é utilizada pelo serviço social nos registros em prontuários.

Na Tabela 5 as respostas dos entrevistados foram organizadas de acordo com a Classificação Brasileira de Ocupações (CBO), e relacionadas com o sexo. 
Tabela 5 - Sujeitos entrevistados que trabalhavam, de acordo com o sexo e o tipo de ocupação.

\begin{tabular}{lcccc}
\hline Tipo de atividade ocupacional & \multicolumn{2}{c}{ Sexo } & \multicolumn{2}{c}{ Total } \\
& Feminino & Masculino & N=34 & \% \\
\hline $\begin{array}{l}\text { Trabalhadores assalariados } \\
\text { administrativos, técnico-científicos }\end{array}$ & 1 & 3 & $\mathbf{4}$ & $\mathbf{1 1 , 7 6}$ \\
$\begin{array}{l}\text { Trabalhadores assalariados da produção, } \\
\text { bens e serviços da administração }\end{array}$ & 6 & 19 & $\mathbf{2 5}$ & $\mathbf{7 3 , 5 3}$ \\
$\begin{array}{l}\text { Trabalhadores por conta própria/ } \\
\text { autônomos: com empregado }\end{array}$ & 0 & 2 & $\mathbf{2}$ & $\mathbf{5 , 8 8}$ \\
$\begin{array}{l}\text { Empregados domésticos urbanos } \\
\text { Trabalhadores rurais assalariados, } \\
\text { volantes e assemelhados }\end{array}$ & 1 & 0 & $\mathbf{1}$ & $\mathbf{2 , 9 4}$ \\
Total & 1 & 1 & $\mathbf{2}$ & $\mathbf{5 , 8 8}$ \\
\hline
\end{tabular}

De acordo com a Tabela 5, a maioria dos entrevistados que trabalhava, 25 (73,53\%), estava enquadrada entre os trabalhadores assalariados da produção, bens e serviços da administração. Dentre as ocupações citadas: vendedores em lojas, operadores de máquina em fábricas, ajudantes de cozinha auxiliares de serviços gerais. Dos $4(11,76 \%)$ que eram trabalhadores assalariados administrativos ou técnico-científicos encontraram-se: técnico em eletrônica, em desenho civil, em designer, auxiliar administrativo. Em 2 (5,88\%) casos, os entrevistados trabalhavam por conta própria/autônomos (depósito de bebidas, serralheria), outros $2(5,88 \%)$ se encaixavam como trabalhadores rurais assalariados, volantes e assemelhados (cortador de cana, entregador de jornais, fazer bicos) e apenas uma (2,94\%) era empregada doméstica (diarista).

Uma pesquisa realizada por Santos; Graciano; Valentim (2007) com 46 pacientes do HRAC/USP, com idades entre 18 a 35 anos, residentes em Bauru e que estavam inseridos no mercado de trabalho, buscou relacionar de forma específica o trabalho com a qualidade de vida desses pacientes. Os resultados mostraram que $81 \%$ eram trabalhadores assalariados, o que corrobora os dados encontrados neste estudo.

Também vem ao encontro desses achados relacionados à escolaridade e trabalho assalariado, os resultados de Bachega (2002), que pesquisou, entre adolescentes de 10 a 19 anos com e sem FLP, os indicadores psicossociais e a sua repercussão na qualidade de vida dos sujeitos. Concluiu que houve limitações dos indivíduos com FLP no desenvolvimento de uma carreira profissional devido à baixa frequência escolar; porém, os mesmos se mostravam satisfeitos com a vida. Resultado semelhante é apontado por Veronez (2007) que encontrou para os pacientes de 18 a 30 anos de idade a condição de trabalho assalariado, a qual se deve à 
baixa escolarização, um problema que afeta o Brasil de forma geral e não apenas as pessoas com FLP.

Os sujeitos entrevistados que não estavam trabalhando, 19 (35,85\%), compreendiam em sua maioria pacientes com idades entre 14 e 16 anos (16,98\%), com idades entre 17 e 19 anos $(15,09 \%)$ e com idades entre 20 e 23 anos $(3,77 \%)$.

Os comentários dos entrevistados que não trabalhavam indicaram que 2 (3,77\%) mulheres, com 18 e 21 anos, já haviam trabalhado como balconista e babá, sem registro em carteira. Dos homens, um $(1,89 \%)$ de 16 anos relatou que fazia serviços esporádicos como designer gráfico, outros $5(9,43 \%)$, com idades de 17 a 23 anos, relataram que já haviam trabalhado, $2(3,77 \%)$ deles com familiares em serviços de pedreiro e contínuo (serviços de banco), $2(3,77 \%)$ iam recomeçar a trabalhar como empacotador de supermercado e entregador de pão, um (1,89\%) já havia atuado como programador mas parou para cursar a graduação e um $(1,89 \%)$ havia perdido o emprego há duas semanas. Ou seja, 12 (22,64\%) desses 19 (35,85\%) já haviam iniciado a vida profissional. Além disso, todos os que não estavam trabalhando estavam estudando.

Como se pode observar nos resultados, um número significativo dos entrevistados era trabalhador assalariado e exercia atividades que requeriam baixo nível de escolaridade. A maior parte da população do Brasil é considerada assalariada, proveniente principalmente do setor de comércio (Dieese, 2012), ou seja, a condição profissional dos pacientes com FLP entrevistados reflete a realidade encontrada na população geral.

Outras informações levantadas foram as atividades relacionadas à religião, esporte, lazer, que oportunizam as relações sociais.

Dentre as questões investigadas, a religião foi enfocada, pois algumas delas proporcionam oportunidades de convivência e participação ativa em grupo. Tal conhecimento vem sendo obtido na experiência da pesquisadora no SETO do HRAC/USP, com pacientes com FLP adolescentes e jovens adultos, observando que, em geral, aqueles que possuem alguma crença religiosa e atuam em suas comunidades, tiveram maior oportunidade de contato com a música, dança, teatro e instrumentos musicais.

As respostas obtidas nas entrevistas mostraram que a maior parte dos sujeitos, 28 $(52,83 \%)$, referiu a religião católica, seguida pela evangélica $(39,62 \%)$, espírita $(5,66 \%)$ e um $(1,89 \%)$ respondeu que não tinha religião. Nos comentários feitos pelos entrevistados, 12 
$(22,64 \%)$ mencionaram que pararam de frequentar templos ou igrejas. Em alguns casos, o tipo de participação mostrou importância, devido à condição do informante: 4 (7,55\%) relataram que cantavam em grupos da igreja, $2(3,77 \%)$ além de cantar também tocavam algum instrumento e um deles dava aulas de instrumentos (clarineta e saxofone) às crianças, jovens e adultos da igreja. Um $(1,89 \%)$ entrevistado comentou que participava de um grupo de dança e outros três adolescentes relataram atividades em grupo de jovens, pastoral, coroinha e missionário.

Praticar atividades esportivas também favorece as relações grupais. Além de proporcionar contato com outras pessoas e atividades em equipe, estudos de Reynolds et al (1990) referiram que a atividade física praticada regularmente diminui os riscos de doenças crônico-degenerativas e apresenta um efeito positivo na qualidade de vida e em outros aspectos psicológicos.

De acordo com os estudos de Oehlschlaeger et al (2004) com adolescentes, os meninos são mais ativos do que as meninas para a prática de esportes e as meninas tendem a ser mais sedentárias.

Os entrevistados foram questionados a respeito da prática de esportes, tendo a maioria deles, 39 (73,58\%), respondido afirmativamente, em sua maior parte $(54,72 \%)$, homens. Desse universo de 39 praticantes de esportes, os tipos mais referidos pelos entrevistados foi o futebol, para a maioria dos homens, 14 (35,90\%), e uma (2,56\%) mulher, seguido de 13 $(33,33 \%)$ respostas referindo mais de uma atividade. As demais modalidades informadas foram ciclismo, academia, atletismo, caminhada, dança e vôlei.

Ainda que $39(73,58 \%)$ dos entrevistados tenham afirmado que praticavam esportes, a frequência informada foi variável, verificando-se que $12(30,77 \%)$ praticavam esporadicamente ou aos finais de semana. Apenas $15(38,46 \%)$ dos entrevistados informaram que praticam quase todos os dias ou todos os dias. Do universo de $14(26,42 \%)$ que não praticavam esportes, $10(71,43 \%)$ relataram que já haviam praticado e parado, $3(21,43 \%)$ deles alegando que foi por causa dos tratamentos cirúrgicos.

Dentre as atividades sociais, os entrevistados foram questionados a respeito das atividades de lazer que realizavam e foram esclarecidos que estas seriam aquelas associadas a situações prazerosas convívio social e diversão. A Tabela 6 apresenta as respostas dos 
entrevistados que foram categorizadas de acordo como o modo como as atividades ocorreram, se individual ou em grupo.

Tabela 6 - Respostas dos sujeitos entrevistados, de acordo com as atividades de lazer informadas, se grupal ou individual.

\begin{tabular}{lcc}
\hline Condição das atividades de lazer & $\mathbf{N}$ & $\mathbf{\%}$ \\
\hline Grupal & 16 & 30,19 \\
Grupal e individual & 34 & 64,15 \\
Individual & 2 & 3,77 \\
Não realiza & 1 & 1,89 \\
Total & $\mathbf{5 3}$ & $\mathbf{1 0 0 , 0 0}$ \\
\hline
\end{tabular}

$\mathrm{Na}$ Tabela 6 as respostas mostraram que na maioria dos casos $(64,15 \%)$, os relatos eram de programas realizados tanto individualmente quanto em grupo, com amigos ou familiares, $16(30,19 \%)$ referiam-se apenas a programas em grupo e apenas $2(3,77 \%)$ entrevistados relataram atividades que desenvolviam sozinhos.

Alguns exemplos de atividades de lazer citada pelos entrevistados: passeios com amigos em lanchonetes, pizzaria, shopping, cinemas, clubes, baladas, praças, shows e atividades ecológicas, assistir à TV, jogar vídeo game, acessar internet, ler, ouvir música, tocar instrumentos musicais (violão, guitarra, saxofone), cozinhar, desenhar.

Esses exemplos de atividades de lazer citadas pelos entrevistados ratificam os estudos de Marcusson; Akerlind; Paulin (2001) que fizeram uma comparação sobre qualidade de vida em geral, bem-estar e saúde entre pessoas com e sem FLP. Verificaram que o grupo de pessoas com FLP foi significativamente mais positivo nos aspectos relacionados a atividades de lazer, apesar de ter apresentado um forte impacto da deficiência nos aspectos relacionados a bem-estar e vida social.

Em três casos foram relatadas atividades de lazer voltadas à família, como uma entrevistada que trabalhava e estudava e comentou não ter atividades de lazer, embora saísse com a mãe, pois seus amigos eram mais velhos e não saía com eles. Outros três casos informaram atividades de lazer exclusivamente na igreja ou com amigos da igreja. 
Em um caso a resposta foi negativa para lazer:

"Atividades de lazer eu não tenho muito não. Fico em casa, assisto TV, fico ouvindo música só, basicamente isso... Amigos !!! Que amigos??” (Sic Entrevistado LFM)

A resposta é de um entrevistado de 15 anos, que cursa o ensino médio, não trabalha e referiu que não tem religião porque não se sente bem em nenhuma. Comentou que só tem uma amiga na escola, seu contato com ela é somente lá, justificando essa situação principalmente pela dificuldade de se relacionar com as pessoas.

De acordo com os estudos de Ribeiro e Moreira (2005), quando a pessoa com FLP atinge a adolescência e não está satisfeita com sua aparência, pode apresentar distúrbios psicológicos e dificuldades no relacionamento interpessoal.

A adolescência é um momento de turbulência e traz questões sociais, de independência e de identidade própria. $\mathrm{O}$ adolescente procura estabelecer uma autocrítica que é separar-se da família de origem, escolher amigos, buscando sua realização pessoal. Mas, a FLP dificulta os acontecimentos dessa fase da vida e pode interferir nos relacionamentos sociais durante os anos do ensino médio (Kapp-Simon 1995, Rumsey e Harcourt 2004 e Maas 2006). No entanto, segundo Rumsey e Harcourt (2004), são os próprios sujeitos que devem decidir sobre a permissão ou não, da interferência da diferença na aparência da sua face, nos seus relacionamentos.

\subsection{Informações sobre o tratamento no HRAC/USP e atividades expressivas e recreativas durante as hospitalizações}

Para conhecer a situação dos entrevistados no HRAC/USP, foram levantadas informações sobre o início e tempo de tratamento, número de internações e cirurgias, atividades expressivas e recreativas que conheciam e haviam participado no SETO durante as hospitalizações. Observou-se que apenas um $(1,89 \%)$ entrevistado havia iniciado o tratamento no HRAC/USP com dois anos e 11 meses e todos os demais $(98,11 \%)$, haviam iniciado antes de 12 meses. 
Em relação ao número de cirurgias a que foram submetidos, quando questionados, os entrevistados não souberam informar. Essa informação foi obtida na base de dados informatizada ou no prontuário do paciente, observando-se que, em geral, foram realizados em torno de cinco a 14 procedimentos por entrevistado, embora em três casos chegassem a 17, 19 e 20 cirurgias. Deve ser destacado que existem procedimentos não relacionados diretamente à reabilitação da fissura, como as cirurgias otorrinolaringológicas em decorrência de problemas auditivos.

A média de cirurgias realizadas foi 10 para cada entrevistado, conforme se verifica na Tabela 7, organizada conforme a faixa etária e o tipo de fissura, fatores que podem influenciar o número de procedimentos a que o paciente se submeteu.

Tabela 7 - Sujeitos entrevistados, de acordo com a faixa etária, a fissura labiopalatina incisiva unilateral ou bilateral e o número médio de cirurgias realizadas.

\begin{tabular}{llccc}
\hline $\begin{array}{l}\text { Faixa etária } \\
\text { em ano }\end{array}$ & $\begin{array}{c}\text { Classificação da fissura } \\
\text { labiopalatina }\end{array}$ & $\begin{array}{c}\text { Número de } \\
\text { pacientes }\end{array}$ & $\begin{array}{c}\text { Número total de } \\
\text { cirurgias }\end{array}$ & $\begin{array}{c}\text { Média de cirurgias } \\
\text { realizadas por paciente }\end{array}$ \\
\hline \multirow{2}{*}{ 14 a 16} & Unilateral & 6 & 50 & 8,33 \\
& Bilateral & 3 & 29 & 9,67 \\
17 a 19 & Unilateral & 15 & 139 & 9,27 \\
& Bilateral & 5 & 60 & 12,00 \\
20 a 23 & Unilateral & 14 & 135 & 9,64 \\
Total & Bilateral & 10 & 117 & 11,70 \\
\hline
\end{tabular}

A Tabela 7 mostra a média de cirurgias realizadas pelos entrevistados. Verificou-se que os entrevistados com fissura transforame incisiva bilateral realizaram um número de procedimentos maior do que os unilaterais.

Outra informação levantada que demonstra a familiaridade dos entrevistados com o HRAC/USP foi o número de internações. Cerca de 11 (20,75\%) dos entrevistados responderam que foram hospitalizados de três a quatro vezes, 20 (37,74\%) informaram de cinco a seis vezes e os demais $22(41,51 \%)$ referiram de sete a 11 internações.

Uma vez que o paciente, quando hospitalizado permanece no SETO, sozinho ou com seu acompanhante, e lá pode participar das atividades expressivas e recreativas oferecidas, uma questão abordou quais atividades eles se lembravam de ter participado durante a internação. As respostas foram classificadas de acordo com os tipos de atividade desenvolvidas: Dinâmica de grupo (atividades de integração, autoconhecimento, relacionamento interpessoal); Expressão dramática (teatros); Expressão plástica (artesanato, 
desenho, recorte e colagem); Expressão corporal e musical (Shows musicais, videokê, mímicas); Jogos (tabuleiros, sinuca, quebra-cabeça, cara a cara, dentre outros); Computador e Leituras.

Os entrevistados foram questionados a respeito das atividades que participaram durante as hospitalizações e as respostas foram quantificadas para elaboração da Tabela 8 , como segue.

Tabela 8 - Respostas dos sujeitos entrevistados, de acordo com as atividades em que participaram durante as hospitalizações.

\begin{tabular}{lcc}
\hline Atividades expressivas e recreativas que participaram & N & \% \\
\hline Jogos & 37 & 69,81 \\
Dinâmica de grupo & 26 & 49,06 \\
Expressão dramática & 19 & 35,85 \\
Expressão plástica & 13 & 24,53 \\
Expressão corporal e musical & 13 & 24,53 \\
Computador & 11 & 20,75 \\
Leituras & 5 & 9,43 \\
\hline
\end{tabular}

Na Tabela 8 as respostas mostraram que os entrevistados tiveram participação em todas as atividades oferecidas e alguns participaram de mais de uma atividade. Os jogos tiveram um maior destaque $(69,81 \%)$, seguido da dinâmica de grupo $(49,06 \%)$ e expressão dramática (35,85\%). As atividades de expressão plástica e corporal musical tiveram o mesmo número de participações $(24,53 \%)$. O computador e as leituras ficaram distribuídos em $(20,75 \%$ e $9,43 \%)$.

Assim, os sujeitos entrevistados informaram significativa participação na maioria das atividades propostas. A importância da realização de atividades expressivas em hospitais foi defendida por Sponton; Guarita; Teixeira, (2007), pois a hospitalização pode prejudicar o desenvolvimento da criança e do adolescente e favorecer sentimentos de depressão, angústia, entre outros. Também Moraes (2007) destacou que as atividades recreativas e expressivas favorecem o relacionamento interpessoal e contribuem para o crescimento e desenvolvimento das crianças hospitalizadas.

Considerando a variedade de atividades oferecidas durante as internações e que os entrevistados poderiam participar, foi solicitado que apontassem aquela que consideravam marcante, cujos resultados são apresentados na Tabela 9. 
Tabela 9 - Respostas dos sujeitos entrevistados sobre a atividade considerada marcante, de acordo com o sexo.

\begin{tabular}{lcccc}
\hline \multirow{2}{*}{ Atividade marcante } & Feminino & Masculino & & \\
& $\mathbf{N}$ & $\mathbf{N}$ & $\mathbf{N}$ & $\mathbf{\%}$ \\
\hline Jogos & 3 & 9 & $\mathbf{1 2}$ & $\mathbf{2 2 , 6 4}$ \\
Dinâmica de grupo & 3 & 8 & $\mathbf{1 1}$ & $\mathbf{2 0 , 7 5}$ \\
Expressão dramática & 4 & 5 & $\mathbf{9}$ & $\mathbf{1 6 , 9 8}$ \\
Expressão plástica & 3 & 5 & $\mathbf{8}$ & $\mathbf{1 5 , 0 9}$ \\
Expressão corporal e musical & 2 & 2 & $\mathbf{4}$ & $\mathbf{7 , 5 5}$ \\
Leituras & 0 & 2 & $\mathbf{2}$ & $\mathbf{3 , 7 7}$ \\
Todas & 1 & 3 & $\mathbf{4}$ & $\mathbf{7 , 5 5}$ \\
Nenhuma & 0 & 3 & $\mathbf{3}$ & $\mathbf{5 , 6 6}$ \\
Total & $\mathbf{1 6}$ & $\mathbf{3 7}$ & $\mathbf{5 3}$ & $\mathbf{1 0 0 , 0 0}$ \\
\hline
\end{tabular}

Dentre as respostas dos entrevistados as atividades mais mencionadas foram os jogos $(22,64 \%)$ e as dinâmicas de grupo (20,75\%). Atividades expressivas também foram lembradas: dramática $(16,98 \%)$, plástica $(15,09 \%)$ e corporal e musical $(7,55 \%)$. As leituras, que os entrevistados fazem sozinhos, foram referidas por $2(3,77 \%)$ entrevistados. Todas as atividades foram consideradas marcantes para 4 (7,55\%) entrevistados e $3(5,66 \%)$ não indicaram uma atividade em especial.

Como pode-se observar as atividades mais citadas pelos entrevistados foram aquelas que exigiam mais interação grupal. Essas atividades mencionadas (Jogos e Dinâmicas de grupo) são compreendidas no contexto do HRAC/USP como facilitadoras das relações interpessoais, afetivas e da comunicação (Afonso, 2000 e Failde, 2007).

Nos comentários emitidos durante as respostas, 9 (16,98\%) entrevistados referiram as amizades que fizeram durante as internações. O entrevistado que não apontou uma atividade marcante, comentou sobre a oportunidade de observar as pessoas, como algo que repercutiu em sua vida acarretando mudanças positivas.

A hospitalização tem sido destacada como fonte de estresse, desestabilidade emocional, angústia, ansiedade, medo e sentimentos de dependência, inferioridade e insegurança (Armond 1996, Carney 2003, Almeida, Rodrigues e Simões 2005, Coyne 2006, Maas 2006 e Basso 2010). É uma situação que exige a adaptação do indivíduo a um novo e desconhecido ambiente e requer a colaboração dos profissionais de saúde. No caso do adolescente com FLP, o tratamento especializado tem início ao nascimento e gera várias hospitalizações até a vida adulta. 
Os resultados obtidos nas respostas e nos comentários dos entrevistados indicaram que os aspectos negativos da internação podem ser amenizados por meio de atividades expressivas e recreativas, bem como pela presença de familiares, o que ocorre durante as hospitalizações no HRAC/USP, quando são oferecidas atividades das quais os pacientes podem participar juntamente com seus acompanhantes.

Dentre os comentários a respeito da atividade marcante, teve um entrevistado que mencionou uma atividade que aprendeu no SETO e trouxe repercussões positivas para sua vida:

\footnotetext{
" a atividade mais marcante para mim foi o tabuleiro(dama), porque depois que eu aprendi a jogar aqui na recreação eu comecei também a me interessar na minha cidade e a participar de campeonatos também"(Sic. Entrevistado TMJ).
}

Este depoimento exemplifica como as atividades expressivas e recreativas oferecidas durante a hospitalização podem contribuir para o crescimento e desenvolvimento da pessoa com FLP, semelhante ao resultado obtido por Moraes (2007) com familiares de crianças com FLP.

\subsection{Convivência e relacionamentos sociais}

Para obter um maior número de informações a respeito do sujeito da pesquisa e investigar se as atividades expressivas e recreativas durante as internações tiveram algumas influência em suas relações sociais, questões foram elaboradas procurando conhecer sobre a convivência com a família, colegas e professores da escola, colegas e superiores no trabalho, bem como conhecidos em geral. A Tabela 10 apresenta as respostas dos entrevistados relacionadas aos familiares, colegas de escola e professores.

Tabela 10 - Respostas dos sujeitos entrevistados sobre a convivência familiar, com os colegas da escola e com os professores.

\begin{tabular}{lcccccc}
\hline \multirow{2}{*}{ Convivência } & Familiares & \multicolumn{2}{c}{ Colegas de escola } & \multicolumn{2}{c}{ Professores } \\
& $\mathbf{N}$ & $\mathbf{\%}$ & $\mathbf{N}$ & $\mathbf{\%}$ & $\mathbf{N}$ & $\mathbf{\%}$ \\
\hline Ótima & 37 & 69,81 & 21 & 61,76 & 15 & 44,12 \\
Boa & 10 & 18,87 & 10 & 29,41 & 15 & 44,12 \\
Regular & 4 & 7,55 & 1 & 2,94 & 2 & 5,88 \\
Ruim & 2 & 3,77 & 2 & 5,88 & 1 & 2,94 \\
Não respondeu & 0 & 00,00 & 0 & 00,00 & 1 & 2,94 \\
Total & $\mathbf{5 3}$ & $\mathbf{1 0 0 , 0 0}$ & $\mathbf{3 4}$ & $\mathbf{1 0 0 , 0 0}$ & $\mathbf{3 4}$ & $\mathbf{1 0 0 , 0 0}$ \\
\hline
\end{tabular}


A convivência familiar foi referida pelos entrevistados, na maioria das vezes, como ótima $(69,81 \%)$ e boa $(18,87 \%)$, enquanto para $4(7,55 \%)$ era regular e para $2(3,77 \%)$ era ruim.

A respeito da convivência na escola foram consideradas as respostas de 34 sujeitos, inclusive de um que não estava mais estudando, mas respondeu significativamente a essa questão. Obteve-se que a convivência com colegas da escola era ótima $(61,76 \%)$ e boa $(29,41 \%)$, apenas um $(2,94 \%)$ regular e $2(5,88 \%)$ ruim. Com os professores observou-se uma ligeira redução nas respostas sobre ótima convivência $(44,12 \%)$ e aumento sobre a boa $(44,12 \%)$, mantendo $2(5,88 \%)$ regular e um $(2,94 \%)$ ruim.

A Figura 3 foi elaborada para melhor visualização das respostas, apresentadas em percentual sobre o total de sujeitos.

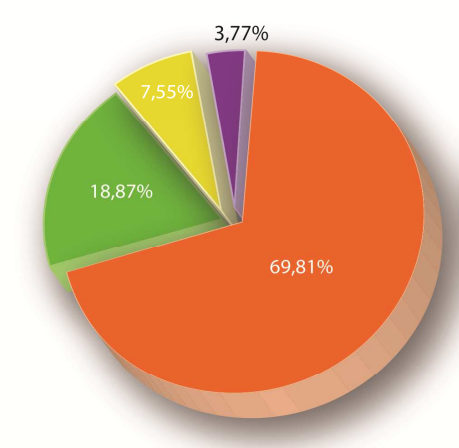

Familiares

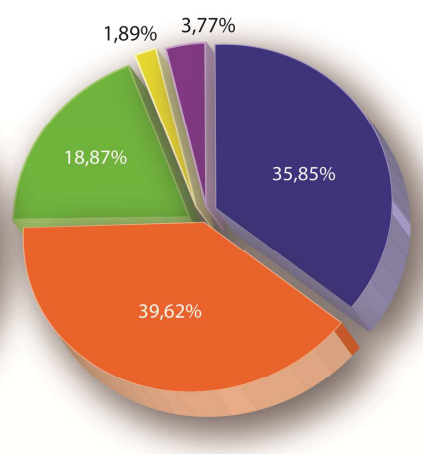

Colegas de escola

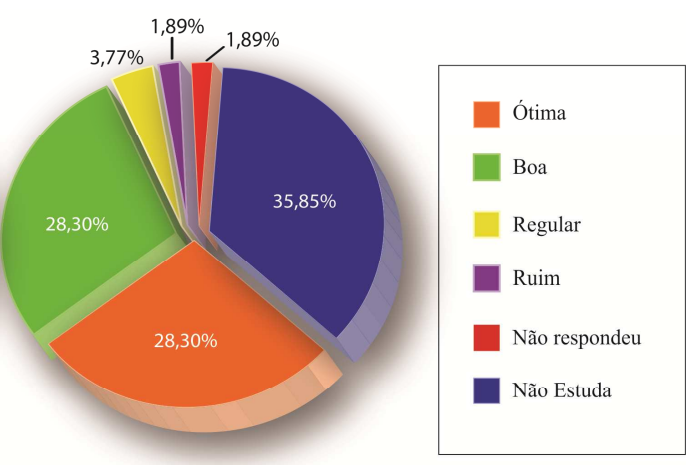

Professores

Figura 3 - Respostas dos sujeitos entrevistados sobre a convivência familiar, com os colegas da escola e com os professores, em percentual.

Na Figura 3, verificou-se que dos 53 entrevistados a maior parte $(69,81 \%)$ relatou que a convivência familiar era ótima. Quanto à convivência com colegas da escola, a maior parte $(39,62 \%)$ também mencionou ótima, enquanto as respostas relacionadas aos professores foram iguais para ótimo e bom $(28,30 \%)$.

Dentre os comentários a respeito da convivência familiar, 31 (58,49\%) comentaram que a família é muito unida, $10(18,87 \%)$ referiram que têm bom relacionamento e $2(3,77 \%)$ mencionaram que a família é o alicerce e tem influência positiva no seu processo de reabilitação. Para exemplificar, seguem alguns trechos das respostas obtidas: 
“... foram um alicerce, uma base, me sustentaram, até hoje eu sou o exemplo da minha família. Nunca me trataram com preconceito, me tratam igual, todas minhas primas, meus primos ... “ (Sic. Entrevistado EVGJ).

“... minha mãe ela teve uma influência muito positiva, a maior preocupação dela sempre foi com minha fala, não foi nem a questão das cirurgias... então ela sempre batalhou pra que a minha convivência com a sociedade fosse ótima, 100\%...”. (Sic. Entrevistado FSC).

Os resultados positivos encontrados nas respostas e comentários dos entrevistados a respeito da convivência familiar sugerem que as famílias adotaram condutas que favoreceram o filho com FLP, promovendo um ambiente propício à sua interação. Tavano (1994), Turner, Rumsey e Sandy (1998), Colares e Richman (2002) e Rafacho (2012), afirmaram que quando ocorre a aceitação da condição da criança e a participação efetiva da família no processo de reabilitação, o indivíduo com FLP apresenta reflexos positivos e uma maior integração com o ambiente familiar e nos diferentes ambientes sociais. $\mathrm{O}$ fato desses pacientes terem iniciado seus tratamentos no HRAC/USP antes dos 12 meses de idade, pode ter colaborado para que os pais tenham assimilado as orientações recebidas dos profissionais especializados e tomado decisões acertadas, facilitadoras do ambiente onde vive o adolescente, que nesta pesquisa, o avalia positivamente.

Kapp-Simon $(2002,2004)$ também referiram a questão do apoio psicológico que a família pode necessitar para lidar com o processo de reabilitação, uma vez que a FLP requer múltiplas cirurgias, além de outros procedimentos como terapia de fala, tratamentos otorrinolaringológicos, odontológicos e ortodônticos, dentre outros. Os pais têm papel fundamental no tratamento da criança, além de aceitar sua condição devem buscar os atendimentos especializados e garantir a presença dela para que os procedimentos sejam realizados.

Um entrevistado de 21 anos, que trabalhava numa borracharia, relatou que tinha boa convivência com os pais, mas com a irmã era ruim e envolvia questões relacionadas a fissura FLP:

"de vez em quando eu brigo com minha irmã, a convivência é mais ou menos, ruim porque de vez em quando ela provoca, eu fico nervoso ... ela fala da minha boca." (Sic. Entrevistado GRO). 
Mas os comentários de 4 (7,55\%) entrevistados do sexo masculino, com idades entre 19 e 23 anos, que classificaram como ótima e boa a convivência com os familiares, contradizem a resposta positiva, pois relataram problemas familiares significativos. Outros comentários deixam dúvidas quanto à ausência de dificuldades, como um entrevistado que expôs que tem pouco contato com os irmãos; outro que trabalha como entregador de jornais e optou por morar com os irmãos e não com um dos pais depois que os mesmos se separaram; um vendedor de artigos religiosos relatou muita briga entre seus pais e, por último, um entrevistado que trabalha como serralheiro e referiu a problemas vivenciados na família, na sua opinião, sem ligação com a FLP.

A escola é ambiente de grande importância no desenvolvimento da pessoa com FLP, onde desde cedo podem enfrentar preconceito dos seus pares. Além dos colegas, a convivência com os professores é primordial tanto para a socialização quanto para o desempenho acadêmico da criança e adolescente com FLP (Tavano, 1994). Assim como a discriminação do indivíduo com FLP no meio social, devido a aparência física comprometida e a dificuldade na comunicação, podem interferir na sua autoestima e prejudicar a sua participação mais efetiva no meio social (Pereira e Motta 1995, Topolski, Edwards e Patrick 2005, Hunt et al 2006 e Chetpakdeechit et al 2009).

Relacionados à convivência na escola, apesar de 21 (61,76\%) dos 33 entrevistados que estudavam afirmarem que a convivência com colegas é ótima, 13 (61,90\%) deles relataram que sofreram preconceito por causa da fissura, que eram ignorados, que as pessoas zombavam, colocavam apelidos. Outros $8(38,10 \%)$ comentaram que aprenderam a lidar com a situação ou criaram recursos para melhor enfrentamento, conforme alguns exemplos:

“... eu sempre sofri imitação, apelido. No começo pra mim foi muito difícil superar isso... tinha vezes que eu queria bater, saia na porrada ... com o passar do tempo eu fui amenizando fui aprendendo a lidar com isso... então, hoje em dia, as vezes rola um pouco esse preconceito, mais não é do tamanho que era antes, rola mais por uma brincadeira...em todos os anos .. sofri preconceito". (Sic. Entrevistado CHBF).

“Por causa da fissura já sofri, principalmente nos primeiros anos de estudo ... acho que foi passando os anos e eles acostumaram, eu melhorei e aí eles perceberam que não adiantava mais ficar zombando, ficar falando, porque todo mundo tem um defeito, não só a gente." (Sic. Entrevistado WSB).

"As pessoas zoavam, caçoavam de mim e do meu irmão (gêmeo), mais eu não esquentava a cabeça não. (Sic. Entrevistado WCM). 
Apesar das dificuldades enfrentadas pelos entrevistados relacionados à escola, no decorrer dos anos foram superadas, como é relatado por alguns deles. Kapp-Simon (2002) refere em seu estudo que o tratamento da pessoa com FLP se estende até o início da fase adulta e neste período ocorrem muitas cirurgias e intervenções, mas no final, o resultado deveria ser um adulto reabilitado e participativo no meio social.

Dos $20(35,74 \%)$ entrevistados que não estavam estudando, mas trabalhavam, 4 $(21,05 \%)$ expressaram as dificuldades que haviam enfrentado na escola pelo preconceito com relação à fissura. Um deles comentou que quando morava em uma cidade pequena as pessoas eram preconceituosas, atitude que ele atribuiu ao fato de não conhecerem a fissura; outros dois mencionaram que haviam sofrido com imitações da sua fala e, outro relato, expôs o processo de superação com o tempo e os amigos:

\footnotetext{
“No começo mesmo foi ruim ... teve um pouco de preconceito ... não me conheciam, eu tava na fase do nariz achatadinho, eles achavam que aquilo lá era contagioso, foi um pouco difícil, depois foi passando .. convivendo com os mesmos colegas e eles foram entendendo ... são os meus melhores amigos ...” (Sic. Entrevistado BMM).
}

\begin{abstract}
“Na escola eu já sofri ... cidadezinha pequena ... uma coisa nova lá ... achavam uma coisa totalmente anormal... eu só chorava, porque eu era pequena, e o preconceito era bem grande”. (Sic. Entrevistado SLAB).
\end{abstract}

"Porque quando eu tava na escola todo mundo tirava sarro... a gente se sentia meio triste, largada, agora eu não ligo mais pra essas coisas, que falam." (Sic. Entrevistado ESF).

Em relação à convivência com professores, 30 (88,24\%) das respostas dos entrevistados que estavam estudando se dividiram igualmente entre ótima e boa. Mas, uma entrevistada de 16 anos que avaliou como ótima sua relação com os professores, comentou o preconceito que já sofreu:

“A professora mentiu um monte de coisas sobre mim ... falava que eu não fazia nada... aí descobriram que ... era tudo mentira.” (Sic. Entrevistado PR). 
Outra entrevistada, também com 16 anos, fez referência não especificamente a convivência com os professores, que considerou regular, mas apontou questões relacionadas ao sistema de ensino da escola:

“... nunca vão, a noite tem grande falta de professor... quando vão não passam nada, daí a gente vai falar alguma coisa a gente é que ta errado, não é pra desrespeitar o professor." (Sic. Entrevistado MDGL).

Dentre $20(35,74 \%)$ entrevistados que não estavam estudando, $2(10,53 \%)$ do sexo feminino, com 19 e 21 anos, trabalhavam na lavoura e como auxiliar de cozinha, respectivamente, fizeram algumas colocações a respeito dos professores na fase escolar:

\footnotetext{
"Porque eu era muito revoltada não conseguia aprender, o professor explicava e eu não consegui enfiar na mente o que era para fazer ... só tirava nota ruim ... brigava e os professores passavam nervoso comigo e aí eu sai da escola e fui trabalhar." (Sic. Entrevistado FRA).
}

“Eles não entendiam o que eu falava.” (Sic. Entrevistado CSO).

Um entrevistado do sexo masculino, 20 anos, que havia parado de estudar, também fez alusão ao seu comportamento, do qual se arrependeu, como uma justificativa para a convivência ruim com os professores:

“Ruim, porque quebrei mesa, joguei ventilador, eu aprontava.” (Sic. Entrevistado FMC).

A aparência facial exerce grande influência nos ambientes sociais frequentados, intervém no contato social, no desenvolvimento da personalidade e no desempenho educacional. A pessoa com FLP pode sofrer discriminação devido a sua aparência comprometida, bem como a sua dificuldade na comunicação, prejudicando a sua participação social efetiva e resultando em baixa autoestima (Lévinas 1980, 1993, Pereira e Motta 1997, Monlleó 2004, Topolski, Edwards e Patrick 2005, Hunt et al 2006, Bastos, Gardenal e Bogo 2008 e Chetpakdeechit et al 2009). 
Lockhart (2003), Kapp-Simon (2004, 2006) e Bastos, Gardenal e Bogo (2008) defenderam uma atenção e suporte profissional à pessoa com malformação, durante seu crescimento, desenvolvimento e longo processo de reabilitação.

Depois da escola, o ambiente de convivência das pessoas quando ingressam na vida adulta passa a ser o local de trabalho. Considerando a faixa etária dos entrevistados, a convivência com os colegas de trabalho foi questionada junto aos 34 que trabalhavam, assim como informações sobre a convivência com os superiores, conforme mostra a Tabela 11.

Tabela 11- Respostas dos sujeitos entrevistados sobre a convivência com os colegas e com os superiores no trabalho.

\begin{tabular}{lcccc}
\hline Convivência & Colegas de trabalho & \multicolumn{2}{c}{ Superiores } \\
& $\mathbf{N}$ & $\mathbf{\%}$ & $\mathbf{N}$ & $\mathbf{\%}$ \\
\hline Ótima & 18 & 52,94 & 15 & 44,12 \\
Boa & 14 & 41,18 & 16 & 47,06 \\
Regular & 0 & 00,00 & 1 & 2,94 \\
Ruim & 0 & 00,00 & 1 & 2,94 \\
Não convive & 1 & 2,94 & 0 & 00,00 \\
Não Respondeu & 1 & 2,94 & 1 & 2,94 \\
Total & $\mathbf{3 4}$ & $\mathbf{1 0 0 , 0 0}$ & $\mathbf{3 4}$ & $\mathbf{1 0 0 , 0 0}$ \\
\hline
\end{tabular}

$\mathrm{Na}$ Tabela 11 com relação aos colegas de trabalho, 18 (52,94\%) entrevistados perceberam como ótima a relação com eles e $14(41,18 \%)$ mencionaram como boa. Um $(2,94 \%)$ não tem convivência e um $(2,94 \%)$ não respondeu. De todos os $32(94,12 \%)$ que consideraram ótima e boa a convivência com os colegas de trabalho, 24 (75,00\%) informaram em seus relatos que existia companheirismo, não brigavam, se divertiam e se respeitavam, como exemplifica o trecho de uma entrevista:

\footnotetext{
“... ótima o pessoal me ajuda, preciso de um conselho eu posso ir atrás, preciso de uma amizade posso ir atrás, tem harmonia no trabalho, rola as brincadeiras lógico para descontrair ...então é muito bom.” (Sic. Entrevistado CHBF).
}

Um entrevistado de 23 anos, porém, que trabalhava como entregador de jornais, apesar de considerar boa a relação fez um comentário sobre desrespeito:

\footnotetext{
“Ah porque tem uns que tira sarro ... pra colocar você lá em baixo. E tem uns que a amizade é mais sincera, tem uns que leva você mais pra deixar você triste, aí eu largo pra lá brinco com eles pra não ter uma relação ruim no trabalho ...” (Sic. Entrevistado FOG).
} 
Ainda sobre a condição de relacionamento no ambiente de trabalho, foram levantadas informações sobre a convivência com os superiores, sendo que $15(44,12 \%)$ dos entrevistados consideraram que era ótima e $16(47,06 \%)$, que era boa. Apenas um entrevistado $(2,94 \%)$ mencionou ser regular e outro $(2,94 \%)$, que era ruim e um $(2,94 \%)$ não respondeu. De todos os $31(91,18 \%)$ que referiram como ótima ou boa a convivência, $16(51,61 \%)$ comentaram em suas respostas que eram respeitados e $2(6,45 \%)$, que os superiores eram compreensivos às suas ausências para comparecer ao HRAC/USP para tratamento. Outros 5 (16,13\%) trabalhavam com pessoas da família e apontaram que isso era um facilitador na relação. Apesar de avaliarem positivamente a convivência, 2 (6,45\%) entrevistados comentaram que os superiores eram bem rigorosos, $2(6,45 \%)$ que não se conheciam direito e um $(3,23 \%)$ respondeu que conversavam somente o necessário.

O único entrevistado que referiu a convivência com os colegas de trabalho como regular, tinha 21 anos, não estava estudando e trabalhava fazendo cobranças para uma rádio justificou sua resposta pela falta de contato com o chefe, que viaja muito a serviço. E o entrevistado que comentou que a convivência era ruim mencionou que seus superiores não entendiam o que ele falava.

Dos 19 (35,85\%) entrevistados que não estavam trabalhando, nove tinham idades entre 14 e 16 anos, sendo que apenas um entrevistado, de 21 anos, havia perdido o emprego duas semanas antes da entrevista e expressou a dificuldade que enfrentou no emprego anterior, devido à necessidade de comparecer aos atendimentos:

“... porque muitas vezes, tinha que vir para o Centrinho e o tratamento aqui não podia faltar e eles ficavam meio assim ...falava você trás um atestado. ...” (Sic. Entrevistado WCM).

Para conhecer a vida dos entrevistados em ambientes mais amplos, fora da família, escola e trabalho, foi questionada como era a convivência deles com colegas e conhecidos em geral. As respostas destacaram a convivência como ótima para $30(56,60 \%)$ entrevistados, como boa para $19(35,85 \%)$ e apenas $4(7,55 \%)$ referiram como regular. Dentre os 49 $(92,45 \%)$ entrevistados que referiram a convivência como ótima e boa, 30 (61,22\%) comentaram que tinham muitos amigos, alguns desde a infância e que são respeitados por eles. 
Nos demais comentários, dos 53 entrevistados, 3 (5,66\%) citaram pessoas da igreja e outros $3(5,66 \%)$ fizeram menções sobre não terem amigos, referindo contato apenas por computador e não terem colegas mas apenas conhecidos.

Ainda investigando os relacionamentos dos entrevistados, outra questão formulada teve por finalidade conhecer a avaliação deles a respeito da sua vida profissional e social. A Tabela 12 traz as respostas obtidas, expressando essas opiniões.

Tabela 12 - Respostas dos sujeitos entrevistados avaliando a vida profissional e social.

\begin{tabular}{lcccc}
\hline \multirow{2}{*}{ Avaliação } & \multicolumn{2}{c}{ Vida profissional } & \multicolumn{2}{c}{ Vida social } \\
& $\mathbf{N = 3 4}$ & $\mathbf{\%}$ & $\mathbf{N = 5 3}$ & $\mathbf{\%}$ \\
\hline Ótima & 14 & 41,18 & 24 & 45,28 \\
Boa & 17 & 50,00 & 23 & 43,40 \\
Regular & 2 & 5,88 & 6 & 11,32 \\
Ruim & 1 & 2,94 & 0 & 00,00 \\
Total & $\mathbf{3 4}$ & $\mathbf{1 0 0 , 0 0}$ & $\mathbf{5 3}$ & $\mathbf{1 0 0 , 0 0}$ \\
\hline
\end{tabular}

De acordo com a Tabela 12, em se tratando de vida profissional, as respostas mostraram que $14(41,18 \%)$ entrevistados que trabalhavam consideravam que sua vida profissional estava ótima e $17(50,00 \%)$ que estava boa. Apenas dois $(5,88 \%)$ avaliaram como regular e um $(2,94 \%)$ como ruim. Dos $31(91,18 \%)$ entrevistados que consideram entre ótima e boa, observou-se nos comentários que 13 (41,94\%) estavam satisfeitos, 7 (22,58\%) pretendiam arrumar emprego melhor, 5 (16,13\%) pretendiam fazer cursos, inclusive de graduação, $2(6,45 \%)$ manifestaram a intenção de se tornarem pastores evangélicos e um $(3,23 \%)$ expressou que gostaria de voltar a ser proprietário de loja.

Quanto à vida social, os entrevistados, em sua maioria, 24 (45,28\%), avaliaram sua vida social ótima, $23(43,40 \%)$ boa e apenas $6(11,32 \%)$ a consideraram regular. Foram significativas as respostas positivas e dentre as justificativas, destacam-se duas entrevistadas que cursam Ensino Superior:

“... eu acho que é boa, poderia ser melhor... ter mais contatos com mais pessoas de fora... não ficar tão apagada... podia ter mais amigos... acho que minha vida começou quando eu comecei a namorar, porque o meu pai não deixava eu sair... eu não tive essa convivência com amiga de ir em festa de sair ...." (Sic. Entrevistado $S C G)$. 
“eu não me comunico muito bem com as pessoas... se a pessoa vier falar comigo eu falo mas, eu não consigo olhar pras pessoas." (Sic. Entrevistado VGS).

Outros dois entrevistados, com 19 e 16 anos, que não trabalhavam, mas estudavam, relataram que a vida social melhorou depois da cirurgia do enxerto ósseo, conforme o exemplo:

"Antes do enxerto eu não gostava não, porque meus dentes eram meio tortos, depois do enxerto de uns tempo pra cá melhorou bastante, a imagem melhorou ...eu não gostava muito de lugar cheio ... de ficar no meio das pessoas e eu meio que me isolava." (Sic. Entrevistado LFSC).

Em dois casos, com 20 e 21 anos, que trabalhavam, mas não estudavam, os relatos mencionaram que as atividades sociais são com os namorados. Outro entrevistado de 23 anos, que avaliou sua vida social como ótima, ainda que mais restrita, comentou sua ligação com amigos da igreja:

“... eu saia muito com meus amigos da igreja, talvez esses 5 últimos anos, as pessoas que eu mais convivi eram pessoas da igreja,... eu estudava com 3 pessoas que também faziam parte do grupo de jovens ... alguns amigos ... trabalhavam comigo, estudavam e participavam do grupo aí a gente convivia todos os dias, convivia mais com eles do que com meu pai, meus irmãos. ...quando eu vim pra cá ... me ligaram pra saber se chegou bem ... quando eu voltei pra me recuperar me visitaram.” (Sic. Entrevistado ES).

Os trechos das entrevistas apresentados retratam as possíveis consequências de uma desfiguração visível em adolescentes tais como: sofrimento psicológico, dificuldades relacionadas à imagem corporal, à qualidade de vida, nos relacionamentos sociais e na autoestima. Assim, os encontros sociais podem oferecer um grande desafio, ainda que algumas pessoas se adaptem às exigências sociais e sejam pouco atingidas pela sua diferença. (Pereira e Mota 1997, Marcusson, Akerlind e Paulin 2001 e Rumsey e Harcourt 2004).

A resposta de uma entrevistada de 20 anos, que estuda e trabalha, mostrou que sua convivência se restringe ao trabalho, alegando que prefere conviver com pessoas mais velhas e considerou que não tem atividades de lazer, pois os amigos são mais velhos e já têm seus compromissos: 
“... é ótima porque as pessoas com quem eu convivo elas sempre estão ali para me ensinar ... eu gosto de ter amizades com pessoas que tem uma idade mais avançada porque é com eles que eu vou aprender mais ... tem uma estagiária que ela tem 20 anos, eu vou conversar com ela e não tem diálogo... eu prefiro pessoas que tenham mais idade porque eu estou aprendendo mais com elas ... (Sic. Entrevistado FSC).

Os aspectos da vida afetiva dos entrevistados com FLP foram levantados em uma questão sobre o relacionamento com o sexo oposto, distribuídas de acordo com as faixas etárias e o sexo, conforme a Tabela 13.

Tabela 13 - Respostas dos sujeitos entrevistados, de acordo com a faixa etária e o sexo, avaliando o relacionamento com o sexo oposto,

\begin{tabular}{|c|c|c|c|c|c|c|c|c|}
\hline \multirow{3}{*}{$\begin{array}{l}\text { Relacionamento } \\
\text { com sexo oposto }\end{array}$} & \multicolumn{6}{|c|}{ Faixa etária em anos } & \multirow{2}{*}{\multicolumn{2}{|c|}{ Total }} \\
\hline & \multicolumn{2}{|c|}{14 a 16} & \multicolumn{2}{|c|}{17 a 19} & \multicolumn{2}{|c|}{20 a 23} & & \\
\hline & $\mathbf{F}$ & $\mathbf{M}$ & $\mathbf{F}$ & M & $\mathbf{F}$ & $\mathbf{M}$ & $\mathbf{N}$ & $\%$ \\
\hline Ótimo & 2 & 1 & 3 & 6 & 3 & 9 & 24 & $45,28 \%$ \\
\hline Bom & 1 & 5 & 2 & 5 & 1 & 5 & 19 & $35,85 \%$ \\
\hline Regular & 0 & 0 & 3 & 1 & 0 & 3 & 7 & $13,21 \%$ \\
\hline Ruim & 0 & 0 & 0 & 0 & 1 & 2 & 3 & $5,66 \%$ \\
\hline Total & 3 & 6 & 8 & 12 & 5 & 19 & 53 & $100,00 \%$ \\
\hline
\end{tabular}

Em geral, de acordo com a Tabela 13, a convivência com pessoas do sexo oposto foi apontada pela maior parte de entrevistados, 24 (45,28\%) como ótima, seguidos de 19 $(35,85 \%)$ que responderam que era boa. As respostas regular e ruim foram indicadas por 7 $(13,21 \%)$ e $3(5,66 \%)$ entrevistados, respectivamente.

Para visualizar as respostas com mais coerência em relação à faixa etária, os dados foram tratados em porcentagem sobre o total de sujeitos para cada faixa, conforme apresenta na Figura 4. 


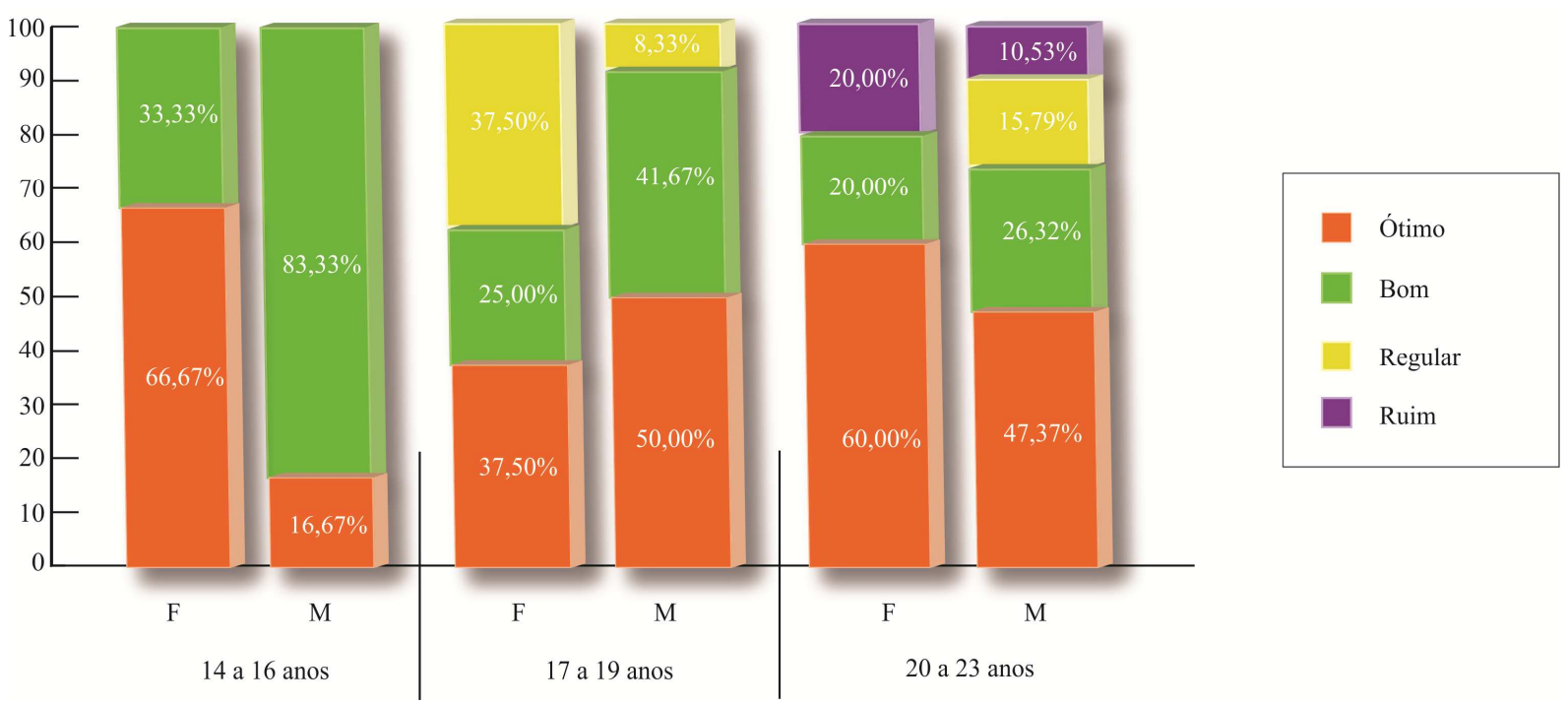

Figura 4 - Respostas dos sujeitos entrevistados, de acordo com a faixa etária e o sexo, avaliando o relacionamento afetivo, em percentual.

A respeito da convivência com o sexo oposto, a Figura 4 permite observar que dos entrevistados na faixa etária dos 14 a 16 anos, a maior parte das mulheres $(66,67 \%)$ informou que era ótima enquanto a maioria dos homens $(83,33 \%)$ informou que era boa. Dos entrevistados da faixa etária dos 17 aos 19 anos, as mulheres se dividiram entre ótima e regular $(37,50 \%)$, enquanto os homens responderam ótima $(50,00 \%)$ ou boa $(41,67 \%)$. Na faixa etária dos 20 aos 23 anos, a maior parte das mulheres (60,00\%) avaliou como ótima, assim como os homens $(47,37 \%)$. Nesta faixa etária correspondente aos sujeitos mais velhos, apareceram respostas sobre a qualidade ruim da convivência com o sexo oposto, podendo indicar um nível maior de exigência ou de crítica, por parte desses indivíduos.

Dentre as respostas indicando ótimo ou bom, da faixa etária dos 14 aos 16 anos, um entrevistado que estuda e fez alguns trabalhos eventuais, referiu que nunca teve aproximação com as meninas e pretende relacionar-se depois que começar a trabalhar:

“... eu prefiro um compromisso sabe, um relacionamento sério...você pode começar a namorar... quando tiver dinheiro pra manter o relacionamento, e como eu não tenho dinheiro... vou ter que esperar um pouco." (Sic. Entrevistado SALR).

Na faixa dos 17 aos 19 anos de idade, também dentre os entrevistados que disseram ser ótimo ou bom, um deles informou que nunca teve relacionamento com pessoas do sexo 
oposto, tratando-se de um paciente que concluiu o ensino médio, trabalhava na venda de artigos religiosos e comentou que pretende ser padre.

Dos entrevistados, $43(81,13 \%)$ que também consideraram entre ótimo e bom o relacionamento com pessoas do sexo oposto, 5 (11,63\%), sendo dois $(4,65 \%)$ da faixa de 14 a 16 anos, um $(2,33 \%)$ de 17 a 19 anos e dois (4,65\%) de 20 a 23 anos, comentaram as dificuldades por causa da fissura, mencionaram o medo da rejeição, da aparência não agradar, a insegurança de se aproximar do outro. Esses entrevistados fizeram comentários, cujos exemplos seguem abaixo:

\footnotetext{
"Estou quase namorando ... está caminhando... as vezes eu penso: Ah ele não vai me querer por causa do meu nariz e tal." (Sic. Entrevistado PR).

"Porque eu as vezes fico com um pouco de vergonha de chegar... eu acho que eu tenho um pouco de medo da rejeição, de ser rejeitado ... mais eu vou." (Sic. Entrevistado AACP).

“... as vezes eu estou a fim da menina e fico com medo de chegar... meio sem jeito...é por causa da fissura, eu tinha medo de chegar e a menina dizer: - Ah! não quero." (Sic. Entrevistado DLC).
}

Um entrevistado que considera sua relação ótima mencionou que usa o diálogo como recurso para se aproximar do sexo oposto, porque valoriza muito mais o conteúdo da pessoa do que sua própria aparência:

\begin{abstract}
"O afetivo é ótimo também porque, apesar de eu não sair de casa muito ... eи nunca tive um problema de tentar conversar com uma garota, e ela falar assim a vocêé isso e aquilo ... quando não dava certo é por outro motivo ou porque a gente não se combinava mesmo...eu desenvolvi uma coisa que é muito importante que é o diálogo ... eu tenho como atrativo o meu diálogo, minha conversa e dá certo, eu acho isso muito mais interessante do que a beleza porque a beleza ela é perecível e o seu conteúdo você vai deixar isso como um legado...eu já namorei...ela considerou meu intelecto, não minha parte física." (Sic. Entrevistado AVSB).
\end{abstract}

As dificuldades apresentadas pelos entrevistados, relacionadas à aparência física e à fala, são implicações estéticas e funcionais da FLP que podem desencadear discriminação e exclusão do indivíduo do meio social. Este por sua vez, insatisfeito com seu rosto, pode 
envergonhar-se da sua aparência, da sua fala quando o palato estiver comprometido, apresentar distúrbios psicológicos. De acordo com Pereira e Mota (1997), Topolski, Edwards e Patrick (2005), Hunt et al (2006), Damiano et al (2007), Bastos, Gardenal e Gobo, (2008) e Chetpakdeechit et al (2009), o apoio psicossocial durante o processo de reabilitação é uma forma de amenizar essa situação.

Rumsey e Harcourt (2004) destacaram que o adolescente com diferenças faciais visíveis tem o nível de autoconsciência da sua aparência intensificado e que os encontros sociais podem apresentar muitos desafios. Mas, muitas pessoas se adaptam e parecem pouco afetadas pela sua diferença. Ribeiro e Moreira (2005) também destacaram que, dependendo da personalidade da pessoa e de como a família aceita e lida com a malformação, a estabilidade emocional pode ser preservada.

Para Rumsey e Harcourt (2004), permitir ou não que a diferença facial interfira nos relacionamentos sociais, incluindo as relações de namoro, durante os anos do ensino médio, é uma decisão que cabe ao adolescente.

\section{$5.4 O$ estágio da reabilitação e as contribuições das atividades}

Tema importante deste estudo foi levantar junto aos entrevistados sua avaliação quanto ao estágio da reabilitação. Considerando a faixa etária em que se encontravam, muitos dos quais já na fase final dos tratamentos, a maioria, 38 (71,70\%) referiu ótimo, 13 (24,53\%) bom, obtendo-se apenas uma resposta regular $(1,89 \%)$ e um entrevistado não respondeu $(1,89 \%)$. Essas respostas foram distribuídas de acordo com a faixa etária, conforme a Tabela 14.

Tabela 14 - Respostas dos sujeitos entrevistados, de acordo com a faixa etária, avaliando o estágio de reabilitação.

\begin{tabular}{|c|c|c|c|c|c|c|c|c|}
\hline \multirow{3}{*}{$\begin{array}{l}\text { Opinião sobre o estágio } \\
\text { de reabilitação }\end{array}$} & \multicolumn{6}{|c|}{ Faixa etária em anos } & \multirow{2}{*}{\multicolumn{2}{|c|}{ Total }} \\
\hline & \multicolumn{2}{|c|}{14 a 16} & \multicolumn{2}{|c|}{17 a 19} & \multicolumn{2}{|c|}{20 a 23} & & \\
\hline & $\mathbf{N}$ & $\%$ & $\mathbf{N}$ & $\%$ & $\mathbf{N}$ & $\%$ & $\mathbf{N}$ & $\%$ \\
\hline Ótimo & 6 & 66,67 & 14 & 70,00 & 18 & 75,00 & 38 & 71,70 \\
\hline Bom & 2 & 22,22 & 5 & 25,00 & 6 & 25,00 & 13 & 24,53 \\
\hline Regular & 0 & 00,00 & 1 & 5,00 & 0 & 00,00 & 1 & 1,89 \\
\hline Não respondeu & 1 & 11,11 & 0 & 00,00 & 0 & 00,00 & 1 & 1,89 \\
\hline Total & 9 & 100,00 & 20 & 100,00 & 24 & 100,00 & 53 & 100,00 \\
\hline
\end{tabular}


Estes achados corroboram o estudo de Bachega (2002) que verificou que 49,2\% dos pacientes com FLP em tratamento no HRAC/USP, com idades entre 10 e 19 anos, estavam satisfeitos com o tratamento. No entanto, durante os comentários dos que responderam positivamente, $21(39,62 \%)$ deles expuseram a sua insatisfação. Em seus relatos $20(37,74 \%)$ referiram que gostariam de melhorar a estética do nariz, 3 (5,66\%) deles também citando a plástica no lábio e apenas um $(1,89 \%)$ falou da sua insatisfação com a cirurgia do lábio.

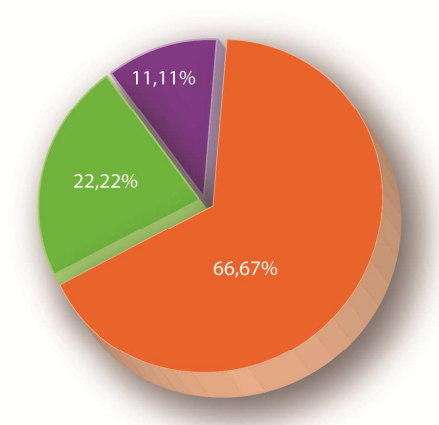

14 a 16 anos

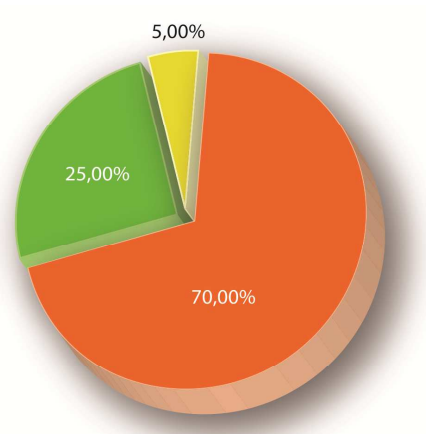

17 a 19 anos

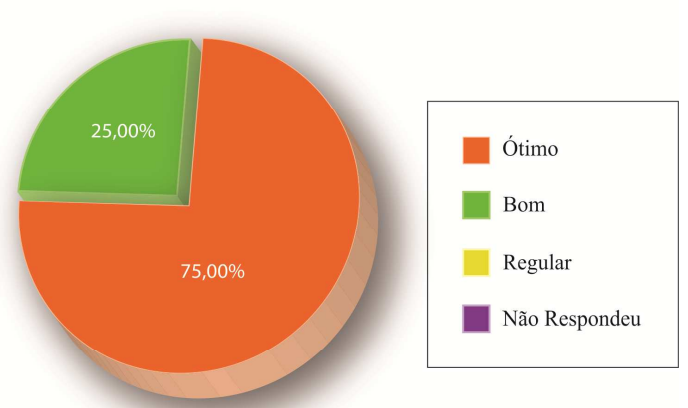

20 a 23 anos

Figura 5 - Respostas dos sujeitos entrevistados, de acordo com a faixa etária, avaliando o estágio de reabilitação, em percentual.

De acordo com a Figura 5 dos nove entrevistados que tinham entre 14 e 16 anos, 6 $(66,67 \%)$ classificaram como ótimo o seu estágio de reabilitação, sendo que dois deles comentaram que estão satisfeitos e os outros 4 (22,50\%) ainda queriam modificar o nariz. Dois $(22,22 \%)$ entrevistados dessa mesma faixa etária que avaliaram a reabilitação como boa, também mencionaram o desejo de fazer a cirurgia do nariz. Para exemplificar, seguem dois relatos de pacientes que ainda estudavam, da faixa etária dos 14 aos 16 anos:

"Quero fazer o nariz, vou fazer a cirurgia plástica, o nariz foi sempre o que me incomodou, os motivos de apelidos sempre foi nariz, tipo nariz torto essas coisas ... vou fazer a plástica e tudo certo....” (Sic. Entrevistado SALR).

“É já mudou bastante mais agora falta fazer a cirurgia de nariz." (Sic. Entrevistado FOV). 
Dos 20 (37,74\%) entrevistados com idade entre 17 e 19 anos, 14 (70,00\%) classificaram como ótimo o seu estágio de reabilitação, tendo 9 (45,00\%) deles comentado que estavam satisfeitos com sua condição, outros $3(15,00 \%)$ gostariam de modificar o nariz e um, o lábio. Dessa mesma faixa etária, $5(25,00 \%)$ pacientes classificaram como bom o seu estágio de reabilitação, sendo que uma paciente relatou estar "esgotada" e quer somente terminar o tratamento ortodôntico, $2(10,00 \%)$ expressaram o desejo de fazer a cirurgia do nariz, $2(10,00 \%)$ queriam fazer plástica do nariz e lábio e um não se achava bonito por causa do lábio e nariz. O entrevistado que se avaliou como regular, referiu que era devido seu estado físico e ansiedade para acabar logo e fazer a cirurgia ortognática.

Entre 20 e 23 anos, havia 24 (45,28\%) entrevistados, os quais, quando questionados a respeito do seu estágio de reabilitação, $18(75,00 \%)$ classificaram como ótimo e dentre os comentários: $8(33,33 \%)$ estavam satisfeitos com a aparência, $7(29,17 \%)$ gostariam de modificar o nariz e $1(4,17 \%)$ queria modificar o lábio, um outro ainda pretendia "tirar" as cicatrizes das cirurgias, mas $2(8,33 \%)$ estavam ansiosos para terminar o tratamento. Dos 6 $(25,00 \%)$ que classificaram como bom, tiveram em comum que gostariam de fazer a correção cirúrgica do nariz, acrescentando em seus comentários a melhora do lábio, das cicatrizes, a cirurgia ortognática e terminar o tratamento odontológico. Um deles expressou que não havia gostado do resultado da última cirurgia e apresentava dificuldade para respirar.

De acordo com as respostas dos entrevistados, observou-se a preocupação em relação à estética do nariz e do lábio, o que significa novos procedimentos cirúrgicos. Oosterkamp et al (2007) obteve resultados semelhantes com adultos com FLP, no que se refere à insatisfação com a aparência do lábio superior, nariz e respiração nasal.

A ansiedade para fazer as cirurgias corretivas e terminar o tratamento, também foi observada por Turner et al (1997) e Kapp-Simon (2004) que discutiram sobre as tensões do adolescente e jovem adulto que, querem fazer logo as cirurgias; mas não querem interromper suas atividades diárias (esporte, trabalho).

A preocupação maior dos pacientes entrevistados com as cirurgias deixa de lado o tratamento ortodôntico, realizado após análise do desenvolvimento craniofacial, que é responsável por grande parte da reabilitação estética e correção das discrepâncias maxilomandibulares (Freitas et al, 2012b). 
A cirurgia ortognática também foi lembrada e pode ser realizada como etapa final do tratamento ortodôntico, o qual abrange o enxerto ósseo alveolar, intervenções realizadas antes e após o enxerto, e se necessário, a cirurgia ortognática que será indicada com o objetivo de melhorar a relação maxilomandibular (Freitas et al, 2012a).

A fala comprometida observada pela pesquisadora nas entrevistas dificultou bastante à transcrição das mesmas, mas não foi comentada por nenhum sujeito como motivo de insatisfação, talvez por não perceberem essa dificuldade. Damiano et al (2007) em um estudo com pais de crianças e adolescentes com FLP, verificaram que as preocupações com a fala e estética afetaram a qualidade de vidas das crianças que estavam próximas da adolescência. Também Chetpakdeechit et al (2009), estudando a compreensão, percepção, valores e como os tratamentos afetam a qualidade de vida de jovens com FLP ou fissura de palato encontraram que estes sentiam-se diferentes dos outros por causa da fala comprometida e da aparência, o que interferia na autoestima.

Mais diretamente relacionado ao objetivo deste estudo, os entrevistados foram questionados a respeito das atividades expressivas e recreativas oferecidas durante os períodos de internação no HRAC/USP, se trouxeram contribuições para vida deles. As respostas mostraram que, para a grande maioria, $50(94,34 \%)$, houve contribuições e apenas $3(5,66 \%)$ responderam negativamente.

Também foram solicitados a comentar sobre a experiência durante as internações no HRAC/USP, relacionadas às atividades expressivas e recreativas de que haviam participado no SETO. Dentre todos, 30 (56,60\%) falaram do ambiente favorável da Recreação, expressando sentimentos como tranquilidade, esperança, valorização, bem-estar e a convivência com outros pacientes, familiares e funcionários durante as atividades. Referiram que as experiências foram bastante significativas para a vida deles, refletindo uma melhora nos relacionamentos interpessoais, diminuição da timidez, melhora da autoimagem e autoestima, por conhecer as histórias de outros pacientes, além de ter a presença do familiar.

Esses resultados vêm ao encontro dos estudos de Carney (2003), Coyne (2006) e Basso (2010) que discutiram sobre a desestabilidade emocional, que a hospitalização provoca, além de implicar na adaptação da pessoa ao novo ambiente, mas mencionaram que toda essa situação pode se minimizada com a qualidade de atendimento dos profissionais da saúde, oferecimento de atividades recreativas e a presença dos familiares. Moraes; Buffa; Motti (2009) também evidenciaram que o brincar, durante a hospitalização, favorece a adaptação da 
criança e de seus familiares no ambiente hospitalar, além de contribuir com condição física e emocional. Principalmente em se tratando de crianças com FLP, que estão sujeitas a várias hospitalizações e procedimentos cirúrgicos.

Outros $15(28,30 \%)$ entrevistados tiveram respostas específicas: 7 (13,21\%) colocaram que o relacionamento com as pessoas fora do Hospital melhorou depois da experiência na Recreação, 5 (9,43\%) afirmaram que a oportunidade de convivência foi um aprendizado para a vida e $3(5,66 \%)$ comentaram que passaram a enfrentar melhor o preconceito.

Além desses, 4 (7,55\%) entrevistados mencionaram os pais como acompanhantes, referindo que participar de atividades com eles foi bastante significativo e marcante em suas vidas.

Para elucidar as respostas positivas seguem alguns depoimentos:

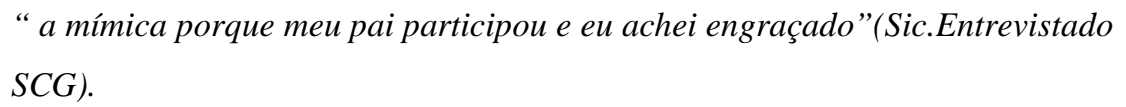
vendo que tem problemas pior ... eu era, uma pessoa mais fechada, eu aprendi a viver aqui, nossa, mudou totalmente lá fora.” (Sic. Entrevistado SLAB).

“A uma experiência única, o tratamento longo, a experiência que fica mesmo, eu guardo na memória sempre que possível, para poder lembrar o que eu passei...fiz muitos amigos ... pena que eu não posso ter uma vida social com eles, moram em outros lugares... senão tivesse a Recreação seria mais isolado... você passa a ver uma pessoa necessitada de uma forma diferente...” (Sic. Entrevistado SST).

“O ambiente é muito favorável aqui na Recreação, passa pra gente uma tranquilidade, uma segurança, esperança é muito bom como um todo, facilita na recuperação...” (Sic. Entrevistado EDS).

“...foram atividades que fez com que eu passasse isso em prática na vida profissional tanto no trabalho como no meio acadêmico... acho que até mesmo a forma de me expressar para os outros”. (Sic. Entrevistado FSC). 
“...eu aprendi a me olhar de um outro jeito, eu aprendi a olhar no espelho, e falar: Não, eu tenho isso, mais vai passar, então me deu uma motivação maior e o Centrinho contribuiu bastante pra isso acontecer”. (Sic. Entrevistado CHBF).

"Essa parte do convívio social, de se comunicar com as outras pessoas de forma mais espontânea, com certeza tudo acaba sendo um tratamento, não é recreação não é um lugar de lazer, ela acaba sendo continuação do tratamento, então é o conjunto da obra.! (Sic. Entrevistado SAF).

Um entrevistado não soube responder sobre a contribuição das atividades, mas relatou que tem lembranças boas, que gostou muito de observar e participou de algumas atividades. Os três entrevistados que haviam respondido que as atividades da Recreação não haviam contribuído para a sua vida, a respeito das experiências durante as internações, mencionaram que não foi um tempo perdido, que haviam gostado da experiência, que as atividades foram "legais" e ajudaram a distrair, que foi bom brincar e conhecer outros pacientes.

Quando questionados em que aspectos ocorreram as contribuições das atividades expressivas e recreativas, nas respostas foram identificadas as categorias: crescimento pessoal, referindo-se a mudanças de comportamentos, melhora da autoimagem e autoestima e, relacionamento interpessoal, quando mencionavam avanços nas relações com outras pessoas. Essas respostas concordaram com aquelas relacionadas à atividade que consideraram marcante, dentre as que participaram durante as internações no HRAC/USP, as quais necessitam de interação pessoal, exigindo do indivíduo algumas habilidades sociais que se estendem para os outros contextos sociais.

Os estudos de Moraes; Buffa; Motti (2009) sugeriram a elaboração de programas que utilizassem atividades recreativas durante a hospitalização, pois de acordo com a visão dos familiares de crianças com FLP do HRAC/USP, essas atividades favorecem o bem-estar físico e emocional da criança, facilitam a interação social, amenizam os sofrimentos causados durante a hospitalização, além de proporcionar uma maior aproximação entre o paciente e seus familiares.

A Tabela 15 a seguir quantifica esses resultados, de acordo com as categorias: crescimento pessoal e relacionamento interpessoal. 
Tabela 15 - Respostas dos sujeitos entrevistados, sobre a contribuição das atividades expressivas e recreativas durante a internação para a vida.

\begin{tabular}{lcc}
\hline $\begin{array}{l}\text { Contribuição das atividades } \\
\text { expressivas e recreativas }\end{array}$ & $\mathbf{N}$ & $\mathbf{\%}$ \\
\hline Crescimento pessoal & 32 & 60,38 \\
Relacionamento interpessoal & 17 & 32,08 \\
Não contribuiu & 3 & 5,66 \\
Não sabe & 1 & 1,89 \\
Total & $\mathbf{5 3}$ & $\mathbf{1 0 0 , 0 0}$ \\
\hline
\end{tabular}

A análise das respostas dos 53 entrevistados quanto à contribuição das atividades recreativas e expressivas de que participaram durante a internação, para a sua vida, mostra que a maior parte atribuiu ao crescimento pessoal $32(60,38 \%)$, seguido de influência no relacionamento interpessoal $17(32,08 \%), 3(5,66 \%)$ que mencionaram que não contribuiu e um $(1,89 \%)$ não soube responder.

Nos comentários das respostas que apontaram o crescimento pessoal, foi observado que a convivência com os outros pacientes e familiares serviu de exemplo para uma maior aceitação da sua condição. Desse modo, os pacientes puderam perceber que não estavam sozinhos com seus problemas e as histórias de superação dos outros pacientes contribuíram para um melhor enfrentamento do preconceito vivido por eles na sociedade, uma mudança na forma de conviver com esse preconceito, sendo também facilitadores da melhora da autoimagem e autoestima.

Nos relatos dos entrevistados verificou-se que o crescimento pessoal e a melhora no relacionamento pessoal mencionadas por grande parte dos sujeitos concordam com os estudos de Kapp-Simon (2004), segundo o qual, para que ocorra o processo de reabilitação é necessário haver um trabalho em conjunto entre a família, escola e equipe de reabilitação.

A importância que os adolescentes e jovens adultos dão ao ambiente físico do hospital está presente nos resultados dos estudos de Carney et al (2003).

Dentre os $32(60,38 \%)$ entrevistados que mencionaram que houve crescimento pessoal, em $10(31,25 \%)$ casos foram relatadas contribuições das atividades grupais realizadas com pacientes e acompanhantes nos períodos de internação, as quais ajudaram a adquirir recursos para enfrentar o preconceito. Referiram que os relatos dos outros pacientes serviram de exemplo, além de diminuir a timidez lá fora e melhorar comportamentos. As atividades corporais contribuem para que o sujeito tenha um novo olhar para seu corpo e suas potencialidades, além de favorecerem o processo de reabilitação (Libermam, 2010). 
Alguns exemplos de respostas a respeito da contribuição para o crescimento pessoal são apresentados:

"A ser mais unido com as pessoas, porque aqui dentro todo mundo um ajuda o outro e lá fora eu levei essa experiência também”. (Sic. Entrevistado TMJ)

"Tinha vergonha de conversar e depois que eu vim aqui eu me soltei mais". (Sic. Entrevistado JWS)

"... o fato de você conversar e conviver com outras pessoas diferentes e vê as fases que as pessoas estão, isso faz a gente crescer mais". (Sic. Entrevistado JDFC).

“... as criança olhavam eu com outro olho, não como uma pessoa normal, e aqui eles me ajudaram a lidar com esses problemas. .. a ter armas com esse problema, .. saio daqui todas as vezes renovado". (Sic. Entrevistado EVGJ).

“... as pessoas contavam histórias que nem sempre eu havia passado ... mas servia como complemento para o meu desenvolvimento social..". (Sic. Entrevistado AVSB).

O último depoimento apresentado vem ao encontro dos estudos de Machado (1996), segundo o qual, para os adolescentes, a importância dada ao grupo de pares é muito significativa. Ao encontrarem, nos seus grupos, um espaço privilegiado de identificação, podem conversar sobre os mesmos assuntos, quer sejam angústias ou problemas.

Há um livro de depoimentos que pais e pacientes escrevem durante a internação, o qual fica disponibilizado em uma das salas do SETO. Um dos pacientes entrevistados, de 23 anos e fissura transforame incisiva bilateral, graduado em Ciências da Computação e trabalhando na área de Informática, depois de ter lido alguns depoimentos relatou a repercussão dos mesmos em sua vida:

“...mães e pais demonstraram ter muita esperança, muita confiança ... em Deus ... nos médicos, eu via muitas pessoas agradecidas, esperançosas... E isso mexeu comigo... essa confiança que todos eles testemunhavam passou pra mim também.. E as histórias .... eu vi história de gente que vem da Amazônia, eu lembro de uma menina que ... morava no interior da Amazônia aí ela teve que viajar 3 dias de barco pra chegar em Manaus e de Manaus pegar o avião pra cá que é mais 12 ou 24 horas de viagem, aí teve mais umas 3 histórias assim que com certeza eu nunca vou esquecer ... é coisa que eu tenho assim que é importante não só na recuperação de algumas cirurgias, mas também para os objetivos de vida.” (Sic. Entrevistado $E D S)$. 
Outras $17(32,08 \%)$ respostas apontaram a contribuição para o relacionamento interpessoal, abrangendo o despertar da solidariedade, a redução da timidez e a melhora de comportamentos, conforme alguns exemplos:

\footnotetext{
"A me relacionar bem com as pessoas porque aqui as atividades em grupo, ajudam a ter um bom relacionamento com as outras pessoas, conversar e comunicar com o próximo também, isso ajuda porque é uma atividade em grupo aqui dentro ...eu não era muito de conversar com outras pessoas lá fora sabe, sei lá eu sentia um pouco de vergonha de chegar nelas e falar alguma coisa, só que eu vejo que essas atividades em grupo orientam também a ter uma comunicação com o próximo". (Sic. Entrevistado OACA).
}

"Ajudou na escola, eu me sentia excluído do grupo, eu acho que eles não gostavam por causa da fissura." (Sic. Entrevistado JMF)

"Porque tirou um pouco a timidez". (Sic. Entrevistado EAS)

\begin{abstract}
"Ajudaram porque antes também, eu era muito tímida, morria de vergonha de falar com as pessoas por conta da fissura, ficava com medo de como a pessoa ia conversar comigo. E essas atividades recreativas me ajudaram porque eu fui perdendo a timidez, há um tempo atrás eu não conversaria com você. A recreação a convivência com outras pessoas me ajudaram." (Sic. Entrevistado BMM).
\end{abstract}

"Comecei depois do teatro ... mais depois eu comecei a me soltar e me soltei. (Sic. Entrevistados $B B F$ ).

"Ajudaram, porque nessa parte que eu falei de me soltar... essa parte de interagir com as pessoas, conversar, fazer amizades influenciou bastante na minha vida também." (Sic. Entrevistado IPN)

Os depoimentos dos entrevistados confirmam que a prática de atividades artísticas, expressivas, recreativas e artesanais no ambiente hospitalar contribuem para minimizar os impactos negativos e favorecem as relações sociais e afetivas (Angerami-Camon, 1988, Saraceno 1999, Sponton, Guarita e Teixeira 2007 e Garcia et al 2011).

As atividades de Dinâmica de Grupo propiciaram uma melhor socialização, tiveram grande influência em aumentar o círculo de amizades. Essa atividade destacada pelos entrevistados utiliza uma terminologia estudada por inúmeros teóricos, com diferentes 
vertentes e compreensões. No contexto do HRAC/USP, prevalece o conceito atribuído por Failde (2007), relacionado a atividades que facilitam a sensibilidade e a conscientização de forma lúdica.

Trabalhar com grupos é uma proposta que propicia a reflexão sobre diversos aspectos, pois as experiências, os conceitos são reinventados, leva os participantes a se sensibilizar, repensar e propor ideias sustentadas pela comunicação e pelas relações interpessoais e afetivas (Afonso, 2000).

Nos grupos, os sujeitos se reconhecem como participantes de uma sociedade. No caso dos pacientes entrevistados, este sentimento de pertencimento pode ser acentuado, por causa da FLP ou pela condição de paciente em processo de reabilitação. Talvez por causa disto, a "Dinâmica de grupo" tenha sido a resposta que trouxe resultados significativos com relação à lembrança e atividade marcante realizada nos processos de hospitalização.

Alguns depoimentos retrataram esses comentários:

“... aprendi muito, muitas coisas que eu tenho na minha vida hoje eu trouxe do Centrinho, o jogo da tesoura, tem que prestar muita atenção... naquilo que está acontecendo .. me marcou, porque me ensinou a prestar um pouquinho mais de atenção nas coisas." (Sic. Entrevistado CHBF).

“.. era muito tímida, morria de vergonha de falar com as pessoas por conta da fissura, ficava com medo de como a pessoa ia conversar comigo. E essas atividades recreativas me ajudaram ..Há um tempo eu não conversaria com você...” (Sic. Entrevistado BMM).

Para Pichon-Riviére \& Quiroga (1998), grupos são um conjunto de pessoas que estão ligadas e articuladas e se propõem implícita ou explicitamente a uma tarefa, com estabelecimento de vínculo entre si. Estes autores acreditam que este vínculo é a base para os processos de comunicação e aprendizagem, já que o sujeito é visto como sujeito social. De acordo com esta definição, este vínculo também é formado durante as atividades realizadas no período de hospitalização dos pacientes no HRAC, o que de fato é um dos objetivos das atividades. 
Alguns relatos exemplificaram contribuição das atividades desenvolvidas durante a hospitalização para a atuação profissional (ocupacional), nas relações afetivas e familiares:

“ você não conhece ninguém (na Recreação), mas sai conversando, participa de alguns jogos .... algumas coisas que eu fiz aqui (na recreação) me ajudaram na entrevista para emprego". (Sic. Entrevistado RPL).

”... bastante positivos pra que eu pudesse ter uma dinâmica lá fora ..trabalho na área administrativa... tenho que ter uma forma de agir, ... rapidez ... concentração em certas coisas ... essas atividades faz com que a gente possa melhora a nossa mente”. (Sic. Entrevistado FSC).

"Valeu como um aprendizado, eu que nunca tinha mexido com aquilo lá (pirógrafo), agora vi como é que faz, porque eu não sabia como fazia aqueles desenho na madeira, então pra mim foi mais um aprendizado... graças à Deus por enquanto eu tô trabalhando então tá tudo bem, mas se um dia eu precisar trabalhar por conta, e como eu sei que aquilo lá é um meio de serviço, eu me interessaria a comprar umas peças pra fazer e vender.”(Sic. Entrevistado LSN).

“Ah, que ajudou mais... que eu lembro mais assim mesmo foi conversar com as meninas da recreação, as palavras que elas foram falando: a servir com simplicidade. A educação delas (referindo-se aos funcionários), me chamou atenção, eu era meio grossão, meio estúpido sabe (com a esposa) ... aí eu fui vendo, conversando com minha mulher, nós fomos tocando pra frente e nos entendemos (Sic. Entrevistado LJO).

Um entrevistado de 23 anos, unilateral, que está se preparando para o vestibular em Direito e trabalha como balconista, relatou melhora no relacionamento no trabalho e crescimento pessoal, pois começou a mudar sua conduta no trabalho tanto na forma de realizá-lo como na relação com os colegas, a partir das observações que fez durante suas internações:

“... a gente vê que o pessoal aqui gosta do que faz, e se dedica, se entrega naquilo que faz, e eu comecei a fazer diferente (referiu-se ao trabalho), a minha chefe falava P. gostei que você se desenvolveu bastante, cresceu muito ... agora é peça fundamental aqui. É tão bom ouvir isso”.(Sic. Entrevistado PHAC). 
Dentre as respostas que se referiam ao crescimento pessoal e relacionamento interpessoal, a maioria, $35(66,04 \%)$, citou que as contribuições ocorreram mais no âmbito social, seguido de $5(9,43 \%)$ que mencionaram no âmbito escolar; 5 (9,43\%) no âmbito ocupacional, $3(5,66 \%)$ que relataram no âmbito afetivo e um $(1,89 \%)$ que citou o familiar.

A análise dos resultados permitiu considerar que as atividades expressivas e recreativas oferecidas durante as internações ao longo da vida da pessoa com FLP no HRAC/USP contribuíram no tratamento e reabilitação, principalmente nos aspectos psicossociais.

A avaliação qualitativa dos dados, conforme enfatizado por Oosterkamp et al (2007), proporcionou conhecimentos a respeito do adolescente e jovem adulto com FLP, permitindo analisar as respostas dos entrevistados às questões abertas, bem como, os comentários sobre alguns aspectos que poderiam estar subentendidos.

A busca de novas informações com adolescentes e jovens adultos poderia abordar a satisfação e a expectativa frente à reabilitação, ou analisar possíveis diferenças de resultados com sujeitos de diferentes regiões do Brasil, contribuindo para aprimorar as etapas e condutas terapêuticas.

A implementação de atividades recreativas e expressivas em hospitais, que recebem jovens adultos e adultos, não só com FLP, mas outras anomalias ou doenças crônicas que exigem várias internações, poderá resultar em vários aspectos positivos, tais como novas pesquisas e publicações, pois há uma escassez, na literatura, de trabalhos específicos como este apresentado no HRAC/USP/Bauru. 


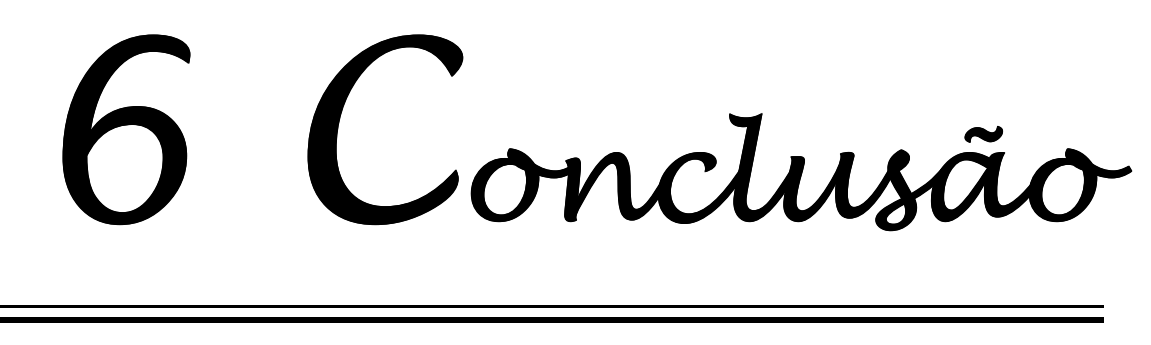





\section{CONCLUSÃO}

O processo de reabilitação da pessoa com FLP envolve também o comprometimento da família, da equipe de reabilitação e da sociedade de modo geral. O HRAC/USP, desde 1967, vem prestando atendimento a essas pessoas e, em toda sua trajetória, vem demonstrado preocupação com o complexo processo de reabilitação, especializado e interdisciplinar, unindo sempre condutas técnicas à humanização.

A pesquisa desenvolvida propôs-se a verificar se as atividades expressivas e recreativas oferecidas no SETO às pessoas com FLP, adolescentes e jovens adultos, durante a hospitalização no HRAC/USP, para a realização dos procedimentos clínicos e cirúrgicos, trouxeram contribuição para a vida dessas pessoas, fora do contexto hospitalar.

Os resultados mostraram que, de modo geral, as respostas dos 53 pacientes entrevistados, com idades entre 14 e 23 anos, foram positivas quanto às contribuições dessas atividades. Foi possível verificar que, na percepção dos pacientes entrevistados, as atividades das quais participaram, enquanto hospitalizados, proporcionaram crescimento pessoal e influenciaram os relacionamentos interpessoais.

O crescimento pessoal foi destacado pela oportunidade de conversar e conviver com pessoas também com FLP. Segundo os entrevistados, os longos anos de tratamento somados ao número de internações e as participações nas atividades oferecidas no SETO fortaleceram a autoimagem e a autoestima, contribuindo para um melhor enfrentamento de preconceito. A melhora no relacionamento interpessoal foi apontada a partir das vivências nas atividades do SETO durante as internações. As respostas positivas indicaram influências na convivência no meio familiar, social, afetivo, escolar e ocupacional.

Foram citadas pelos entrevistados como marcantes, dentre as atividades que participaram, aquelas que envolviam interação pessoal e que exigiam do indivíduo algumas habilidades sociais que se estenderam para os outros contextos.

Quando solicitados a comentar sobre as experiências durante as internações no HRAC/USP, relacionadas às atividades no SETO, mais da metade dos entrevistados mencionou o ambiente favorável da Recreação, assim como a convivência com outros pacientes, familiar e funcionários durante as atividades. Também destacaram que as 
experiências trouxeram contribuições em suas vidas nos aspectos ligados aos relacionamentos interpessoais, autoestima e autoimagem.

Diante desses achados, verificou-se que as atividades expressivas e recreativas oferecidas durante as internações merecem destaque, pois propiciam vínculos, inter-relação entre pacientes, familiares e profissionais, proporcionando melhor enfrentamento da condição de pessoa com FLP.

Outras investigações poderão ser realizadas com pacientes atendidos no Hospital, vindos de outras regiões do país, de outras faixas etárias, de outros ambientes socioculturais, a fim de analisar possíveis diferenças nos resultados.

As atividades oferecidas no SETO-HRAC/USP também poderiam servir de exemplo para outros hospitais, não restritos às pessoas com FLP, que necessitem de várias internações durante a vida, tendo em vista que este tipo de apoio traz contribuições para o tratamento e para o processo de reabilitação. 
Referencias 



\section{REFERÊNCIAS}

Aberastury A, Knobel M. Adolescência normal. Porto Alegre: Artes Médicas; 1981.

Abyholm FE. Cleft lip and palate in norwegian population. II. A numerical study of 1555 CLP: patients admitted for sugircal treatment. 1954-75. Scand J Plast Reconstr Surg. 1978;12:35-43.

Afonso M LM. Oficinas em Dinâmicas de Grupo: um método de intervenção psicossocial. Belo horizonte: Edições do campo Social; 2000.

Aiello CA, Silva Filho OG, Freitas JAS. Fissuras labiopalatais: uma visão contemporânea do processo reabilitador. In: Mugayar LRF. Pacientes portadores de necessidades especiais: manual de odontologia e saúde oral. São Paulo: Pancast; 2000. p.111-39.

Almeida IS, Rodrigues BMRD, Simões SMF. Desvelando o cotidiano do adolescente hospitalizado. Rev. bras. Enferm. 2005;58(2):147-151.

Angerami-Camon VA. A psicologia no hospital. São Paulo: Traço; 1988.

Armond LC. Buscando compreender o fenômeno da hospitalização para o adolescente [dissertação]. Belo Horizonte: Escola de Enfermagem, Universidade Federal de Minas Gerais; 1996.

Bachega M I. Indicadores psicossociais e repercussões na qualidade de vida de adolescentes com fissura labiopalatal [tese]. Botucatu: Faculdade de Medicina de Botucatu, Universidade Estadual Paulista; 2002.

Baker SR, Owens J, Stern M, Willmot D. Coping strategies and social support in the family impact of cleft lip and palate and parents' adjustment and psychological distress. Cleft Palate Craniofac J. 2009;46(3):229-236.

Balestriero M. A criança e a poesia: um encontro possível: a poesia na $5^{a}$. Série [tese]. Marília: Universidade Estadual de São Paulo; 1998.

Bardin L. Análise de Conteúdo. Portugal: Ed. 70; 2008.

Basso R. Expressive Arts in Pediatric Orientation Groups. J Pediatr Nurs. 2010;25(6):482489. 
Bastos PRHO, Gardenal M, Bogo D. O Ajustamento social dos portadores de anomalias craniofaciais e a práxis Humanista [revisão].Arq. int. otorrinolaringol.2008;12(2):280-288.

Benjamin C. Reforma, nação e barbaria. Inscrita; 1997.

Brasil. Lei n ${ }^{\circ} 10.097$, de 19 de Dezembro de 2000. Altera dispositivos da Consolidação das Leis do Trabalho - CLT, aprovada pelo Decreto-Lei n. 5.452, de $1^{\circ}$ de maio de 1943 [online]. Diário Oficial da União. 20 dez 2000 [acesso em 26 out 2012]. Disponível em: http://www.planalto.gov.br/ccivil_03/leis/L10097.htm

Brasil. Lei $\mathrm{n}^{\circ}$ 11.274, de 6 de fevereiro de 2006. Altera redação dos arts. 29, 30, 32 e 87 da Lei $\mathrm{n}^{\circ}$ 9.394, de 20 de dezembro de 1996, que estabelece sobre as diretrizes e bases da educação [online]. Diário Oficial da União. 7 de fev 2006 [acesso em 26 out 2012]. Disponível: http://www.planalto.gov.br/ccivil_03/_Ato2004-2006/2006/Lei/L11274.htm

Brasil. Lei $\mathrm{n}^{\circ} .8069$, de 13 de julho de 1990. Dispõe sobre o Estatuto da criança e do adolescente e dá outras providências. [online]. Presidência da República Casa Civil Subchefia para assuntos jurídicos. 13 de jul de 1990 [acesso em 26 out 2012]. Disponível em: http://www.planalto.gov.br/ccivil_03/leis/L8069.htm

Brasil. Ministério do Trabalho. Classificação Brasileira de ocupações CBO - 1994. Brasília: Secretaria de Políticas de Emprego e Salário. 1995; 2v.

Brasil. Ministério do Trabalho e Emprego. CBO - Classificação Brasileira de Ocupações 2002. [Acesso em 12 out 2012]. Disponível em: 〈http://www.mtecbo.gov.br/indexFaqs.asp〉.

Byrnes AL, Berk NW, Cooper ME, Marazita ML. Parental evaluation of informing interviews for cleft lip and/or palate. Pediatrics. 2003;112(2):308-313.

Capelloza Filho L, Alvares ALG, Rossato C, Vale DMV, Janson GRP, Beltrami LER. Conceitos vigentes na etiologia das fissuras lábio-palatinas. Rev Bras Cir. 1988;78:233-40.

Carney T, Murphy S, McClure J, Bishop E, Kerr C, Parker J, et al.Children's views of hospitalization: an exploratory study of data collection. J Child Health Care. 2003;7(1):27-40.

Chetpakdeechit W, Hallberg U, Hagberg C, Mohlin B. Social life aspects of young adults with cleft lip and palate: grounded theory approach. Acta Odontol Scand. 2009;67(2):122128.

Colares V, Richman L. Fatores psicológicos e sociais relacionados às crianças portadoras de fissuras labiopalatais. Pediatr moder. 2002; 38 (11):213-16. 
Correia LM, Peres JAS, Peres MIM, Richardson RJ, Wanderley JCV. Pesquisa social: métodos e técnicas. São Paulo: Atlas; 1985.

Coyne I. Children's experiences of hospitalization. J Child Health Care. 2006;10(4):326-336.

Damiano PC, Tyler MC, Romitti PA, Momany ET, Jones MP, Canady JW, et al. Healthrelated quality of life among preadolescent children with oral clefts: the mother's perspective. Pediatrics. 2007;120 (2):283-90.

Departamento intersindical de estatística e Estudos socioeconômicos (Dieese). A ocupação dos jovens nos mercados de trabalho metropolitanos. [periódico na Internet]. [Acesso em 12 out. 2012];[aproximadamente 38p.]. Disponível em:

<http://www.dieese.org.br/esp/estpesq24_jovensocupados.pdf >.

Dixon MJ, Marazita ML, Beaty TH, Murray JC. Cleft lip and palate: understanding genetic and environmental influences. Nat Rev Genet.2011;12(3):167-78.

Eisenstein E. Atraso puberal e desnutrição crônica [tese]. São Paulo: Escola Paulista de Medicina, Universidade Federal de São Paulo; 1999.

Failde, I. Manual do facilitador para dinâmicas de grupo. Campinas, SP: Papirus; 2007.

Frase FC. The genetics of cleft lip and palate. Am J Hum Genet. 1970; 22:336-52.

Freitas JAS, Garib DG, Oliveira M, Lauris RCMC, Almeida ALPF, Neves LT, et al. Rehabilitative treatment of cleft lip and palate: experience of the Hospital for Rehabilitation of Craniofacial Anomalies-USP (HRAC-USP)-Part 2: Pediatric Dentistry and Orthodontics. J Appl Oral Sci. 2012a; 20(2):272-85.

Freitas JAS, Neves LT, Almeida ALPF, Garib DG, Trindade-Suedam IK, Yaedú RYF, et al. Rehabilitative treatment of cleft lip and palate: experience of the Hospital for Rehabilitation of Craniofacial Anomalies/USP (HRAC/USP)-Part 1: overall aspects. J Appl Oral Sci. 2012b; 20(1):9-15.

Gainza VH. Estudos de psicopedagogia musical. São Paulo: Summus; 1988.

Garcia JR, Neme CMB, Chinelatto MCMP. Body image in adult patients with cleft lip palate: an analysis through human figure drawing. Braz. J. Dismorf. S. Disorders, Bauru. 1999; 2(2):17-26. 
Garcia NR, Pacciulio AM, Pinto-Panúncio MP, Pfeifer LL. Intervenção Terapêutica Ocupacional junto a Adolescentes com Câncer em Contexto Hospitalar. Rev Bras Cancerol. 2011; 57(4):519-24.

Gejer D, Françoso LA, Reato LFNR. Sexualidade e saúde reprodutiva na adolescência. São Paulo: Atheneu; 2001.

Gil AC. Como elaborar projetos de pesquisa. 3a ed. São Paulo: Atlas; 1991.

Graciano MIG, Lehfeld NAS, Neves F. A., A. Critérios de avaliação para a classificação sócio-econômica: elementos de atualização. Serv Social Realid. 1999;8 (1):109-28.

Graciano MIG, Lehfeld NAS, Neves F. A. Critérios de avaliação para classificação sócioeconômica: elementos para a atualização parte II. Serv. Social Realid. 1996; 5 (2):171-20.

Graciano MIG, Lehfeld NAS. Estudo socioeconômico: indicadores e metodologia numa abordagem contemporânea. Serv. Social Saúde. 2010; 9 (9):157-85.

Graciano MIG, Tavano LDA, Bachega MI. Aspectos Psicossociais da Reabilitação. In: Trindade IEK, Silva Filho OG, coordenadores. Fissuras Labiopalatinas: Uma Abordagem Interdisciplinar. São Paulo: Santos; 2007; 311-33.

Greene JC. Epidemiologic research: 1964-1967. J Am Dent Assoc. 1968; 76:1350-6

Greene JC, Vermillion JR, Hays S, Gibbens SF, Kerschbaum S. Epidemiologic study of cleft lip and palate in four states. J Am Dent Assoc. 1964; 68:387-04.

Hunt O, Burden D, Hepper P, Stevenson M, Johnston C. Self-reports of psychosocial functioning among children and young adults with cleft lip and palate. Cleft Palate Craniofac J. 2006;43(5):598-605.

Ibrahim D, Faco EFS, Santos Filho JHG, Faco RAS. Enxerto ósseo alveolar secundário em pacientes portadores de fissuras lábio-palatais: um protocolo de tratamento. Rev. Fac. Odontol. 2004;16(2):13-18.

Kapp-Simon KA. A brief overview of psychological issues in cleft lip and palate. In: Berkowitz [section III; Springer Berlin Heidelberg]. Cleft Lip and Palate; 2006, 2a ed.:257261.

Kapp-Simon KA, Simon D. Meeting the challenge: a social skills training program for adolescents with special needs. Chicago: University of Illnois; 1991. 
Kapp-Simon KA. Psychological care of children with cleft lip and palate in the family. In: Wyszynski DF, editor. Cleft lip and palate: from origin to treatment. New York: Oxford University Press; 2002:412- 423.

Kapp-Simon KA. Psychological interventions for the adolescent with cleft lip and palate. Cleft Palate Craniofac J.1995;32(2):104-108

Kapp-Simon KA. Psychological issues in cleft lip and palate. Clin Plast Surg; 2004, 31(2):347-352.

Lévinas E. Humanismo do outro homem. Petrópolis: Vozes; 1993.

Lévinas E. Totalidade e Infinito. Ed. 70, Lisboa, Portugal;1980.

Liberman F. O corpo como pulso. Comunicação Educação. [periódico na Internet]. Abr./jun. 2010.[Acesso em 26 de out de 2012]; 14 (33), p.449-60. Disponível em: http://www.scielo.br/pdf/icse/v14n33/a17v14n33.pdf

Liberman F. Trabalho corporal, música, teatro e dança em terapia ocupacional: clínica e formação. Cad Centro Universitário São Camilo. 2002;8(3):39-43.

Lockhart E. The mental health needs of children and adolescents with cleft lip and/or palate. Clin child psychol psychiatry. 2003;8(1):7-16.

Maas T. O processo de transição do ser adolescente hospitalizado com doença crônica sob a ótica da enfermagem [dissertação]. Curitiba: Universidade Federal do Paraná; 2006.

Machado PJ. Culturas juvenis. Lisboa: Imprensa Nacional Casa da Moeda; 1996.

Marconi MA, Lakatos EM. Fundamentos de metodologia Científica. 5a ed. São Paulo: Atlas; 2003.

Marcusson A, Akerlind I, Paulin G. Quality of life in adults with repaired complete cleft lip and palate. Cleft Palate Craniofac J. 2001;38(4):379-385.

Minayo MCS. O desafio do conhecimento: pesquisa qualitativa em saúde. 6a ed. São PauloRio de Janeiro:Hucitec-Abrasco; 1999.

Minervino-Pereira ACM. O processo de enfrentamento vivido por pais de indivíduos com fissura labiopalatina, nas diferentes fases do desenvolvimento [tese]. Bauru. Hospital de Reabilitação de Anomalias Craniofaciais, Universidade de São Paulo; 2005. 
Modolin MLA, Cerqueira EMM. Etiopatogenia. In: Altmannn EBC. (org.). Fissuras labiopalatinas. 4a ed. Carapicuíba: Pró-Fono; 1997. p. 25-30.

Monlleó IL. Anomalias craniofaciais, genética e saúde pública: contribuições para o reconhecimento da situação atual da assistência no Sistema Único de Saúde [dissertação]. Campinas: Faculdade de Ciências Médicas da Universidade Estadual de Campinas; 2004.

Moraes MCAF. A influência das atividades expressivas e recreativas em crianças hospitalizadas com fissura labiopalatina: a visão dos familiares [dissertação]. Bauru. Hospital de Reabilitação de Anomalias Craniofaciais, Universidade de São Paulo; 2007.

Moraes MCAF, Buffa MJMB, Motti TFG. As atividades expressivas e recreativas em crianças com fissura labiopalatina hospitalizadas: visão dos familiares. Rev. bras. educ. espec. $2009 ; 15(3): 453-470$.

Mossey PA, Little J, Munger RG, Dixon MJ, Shaw WC. Cleft lip and palate. The Lancet. 2009;374(9703):1773-1785.

Nagem Filho H, Morais N, Rocha RGF. Contribuição para o estudo da previdência das malformações congênitas labiopalatinas na população escolar de Bauru. Rev. Fac. Odonto. 1968;72: 239-46.

Neves JL. Pesquisa qualitativa - características, usos e possibilidades. Caderno de pesquisa em admistração, São Paulo. 1996;1(3):1-5

Oaklander V. Descobrindo crianças: abordagem gestáltica com crianças e adolescentes. São Paulo: Summus; 1980.

Oehlschlaeger MHK, Pinheiro RT, Horta B, Gelatti C e Santana P. Prevalência e fatores associados ao sedentarismo em adolescentes de área urbana. Rev. Saúde Pública. 2004;38 (2):157-63.

Oosterkamp B, Dijkstra P, Remmelink H, Van Oort R, Goorhuis-Brouwer S, Sandham A, et al. Satisfaction with treatment outcome in bilateral cleft lip and palate patients. Int J Oral Maxillofac Surg.. 2007; 36(10):890-895.

Pereira ACMM, Mota SAS. Análise da influência do estigma físico nas relações interpessoais em indivíduos com malformações craniofaciais: fissura lábio-palatina. Mimeses.1997;18:14354.

Perry A. A model of stress in families of children with development disabilities: Clinical and research applications. Journal of Development Disabilities. 2004;11(1):1-16. 
Peter JP, Chinsky RR, Fisher MJ. Sociological aspects of cleft palate adults: III. Vocacional and economic aspects. Cleft Palate Craniofac J. 1975;12(1):193-99.

Pichon-Riviere E \& Quiroga AP. Psicologia da vida cotidiana. São Paulo: Martins Fontes; 1998.

Pinho LB, Kantorski LP. Reflectioning about the families psychosocial contex of patients in the emergency. Cien e Enferm.2004;10:67-77.

Porto O. Psicopedagogia hospitalar: intermediando a humanização na saúde. Rio de Janeiro:Wak;2008.

Rafacho, MB. A Internet como um recurso de acesso à informação para pais de crianças com fissura labiopalatina. [dissertação]. Bauru: Hospital de Reabilitação de Anomalias Craniofaciais, Universidade São Paulo; 2012.

Reynolds KD, Killen JD, Bryson SW, Maron DJ, Taylor CB, Maccoby N, et al. Psychosocial predictors of physical activity in adolescents. Prev Med. 1990;19: 541-51.

Ribeiro EM, Moreira ASCG. Atualização sobre o tratamento multidisciplinar das fissuras labiais e palatinas. Rev Bras Promoção Saúde. 2005;18(1):31-40.

Rumsey N, Harcourt D. Body image and disfigurement: issues and interventions. Body Image I. 2004;1(1):83-97.

Santos SRL, Graciano GIM, Valentim PAACR. Trabalho e qualidade de vida de pessoas com fissura labiopalatina inseridas no mercado profissional em Bauru. Serv Social Realid 2007;16(2):83-121.

Salmela M, Salanterä S, Ruotsalainen T, Aronen ET. Coping strategies for hospital-related fears in pre-school-aged children. J. Paediatric Child Health. 2010;46(3):108-114.

Saraceno B: Libertando identidades: da reabilitação psicossocial à cidadania possível. Belo Horizonte, Rio de Janeiro: Te Corá Editora; 1999.

Silva Filho OG, Ferrari Junior FM, Rocha DL, Freitas JAS. Classificação das fissuras lábiopalatais: breve histórico, considerações clínicas e sugestões de modificação. Rev Bras Cir. 1992;82:59-65. 
Silva Filho OG, Freitas JA de S. Caracterização Morfológica e Origem Embrionária. In: Trindade IEK, Silva Filho OG (coord.). Fissuras labiopalatinas: uma abordagem interdisciplinar. São Paulo: Santos; 2007.

Sinko K, Jagsch R, Prechtl V, Watzinger F, Hollmann K, Baumann A. Evaluation of esthetic, functional, and quality-of-life outcome in adult cleft lip and palate patients. Cleft Palate Craniofac J. 2005;42(4):355-61.

Souza Freitas JA. Centro de Pesquisa e Reabilitação de Lesões Lábio-Palatais. Bauru: Faculdade de Odontologia de Bauru, Universidade de São Paulo; 1974.

Speltz LM, Endriga CM, Fisher P, Mason AC. Early predictors of attachment in infants with cleft lip and/or palate. Child Development. 1997; 68:12-25.

Spina V, Psilakis JM, Lapa FS, Ferreira MC. Classificação das fissuras lábio-palatais: sugestão de modificação. Rev Hosp Clin Fac Med. São Paulo, 1972; 27:5-6.

Sponton MHC, Guarita RV, Teixeira SDAS. Despertar arte e cultura. Humanização hospitalar por meio da arte e cultura. In: $3^{\circ}$ Fórum ABM de responsabilidade social; 2007;25-30.

Tavano LD. Análise da integração escolar de uma criança portadora de lesão lábio-palatal [dissertação]. São Carlos: Universidade Federal de São Carlos; 1994.

Tavano LD. Avaliação do desempenho psicossocial de pacientes portadores de fissura lábiopalatina submetidos a tratamento multidisciplinar no Hospital de Reabilitação de Anomalias Craniofaciais-USP [tese]. Bauru: Hospital de Reabilitação de Anomalias Craniofaciais, Universidade São Paulo; 2000.

Topolski TD, Edwards TC, Patrick DL. Quality of life: how do adolescents with facial differences compare with other adolescents? Cleft Palate Craniofac J.2005;42(1):25-32.

Turato ER. Métodos qualitativos e quantitativos na área da saúde: definições, diferenças e seus objetos de pesquisa. Rev. Saúde Pública. 2005;39(3):507-14.

Turato ER. Tratado de metodologia da pesquisa clínico-qualitativa: construção técnicoepistemológica, discussão comparada e aplicação nas áreas da saúde e humanas. 2 ed. Petrópolis: Vozes; 2003.

Turner SR, Rumsey N, Sandy R. Psychological aspects of cleft lip and palate. Eur J Orthod. London. 1998;20:407-415. 
Turner SR, Thomas WN, Dowell T, Rumsey N, Sandy JR. Psychological outcomes amongst cleft patients and their families. Br J Plast Surg. 1997;50:1-9.

Universidade de São Paulo, Hospital de Reabilitação de Anomalias Craniofaciais. Etapas e Condutas Terapêuticas - Hospital de Reabilitação de Anomalias Craniofaciais - Universidade de São Paulo e Fundação para o estudo e tratamento deformidades craniofaciais: fissuras labiopalatais, anomalias craniofaciais, deficiências auditivas, síndromes. Bauru: Hospital de Reabilitação de Anomalias Craniofaciais, Universidade de São Paulo; 2008.

Veronez FS. Avaliação da qualidade de vida em pacientes adultos com fissura labiopalatina [Dissertação]. Bauru: Hospital de Reabilitação de Anomalias Craniofaciais, Universidade de São Paulo; 2007.

Wehby G, Cassell CH. The impact of orofacial clefts on quality of life and healthcare use and costs. Oral Dis. 2010;16(1):3-10. 



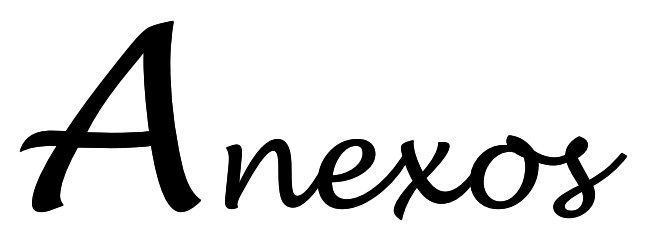



Anexo 1 - Aprovação pelo Comitê de Ética em Pesquisa em seres humanos

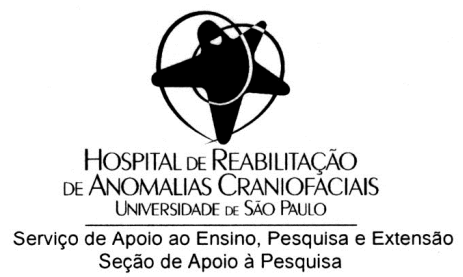

Ofício nº 017/2010-SVAPEPE-CEP

Bauru, 05 de março de 2010.

Prezado(a) Senhor(a)

O projeto de pesquisa encaminhado a este Comitê de Ética em Pesquisa em Seres Humanos, denominado "O significado das atividades expressivas e recreativas na vida da pessoa com fissura labiopalatina: uma análise baseada nos períodos de hospitalização", de autoria de MARCIA CRISTINA ALMENDROS FERNANDES MORAES desenvolvido sob sua orientação, foi enviado ao relator para avaliação.

$\mathrm{Na}$ reunião de $\mathbf{2 3}$ de fevereiro de $\mathbf{2 0 1 0}$, o parecer do relator aprovando o projeto, foi aceito pelo Comitê, considerando que não existem infrações éticas pendentes para início da pesquisa. Solicitamos a V.Sa. a gentileza de comunicar o parecer ao(à) pesquisador(a) e anexar o presente ofício ao projeto pois o mesmo será necessário para futura publicação do trabalho.

O(A) pesquisador(a) fica responsável pela entrega na SVAPEPE - Apoio ao Projeto de Pesquisa dos relatórios semestrais, bem como, comunicar ao CEP todas as alterações que possam ocorrer no projeto.

Informamos que após o recebimento do trabalho concluído, este Comitê enviará o parecer final para publicação.

Atenciosamente,

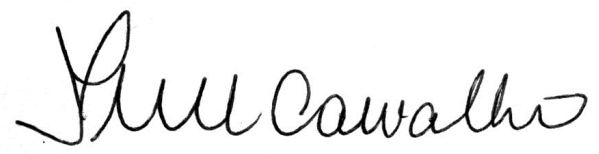

PROFA. DRA. IZABEL MARIA MARCHI DE CARVALHO Coordenadora do Comitê de Ética em Pesquisa em Seres Humanos do HRAC-USP

IImo Sr

Prof. Dr. José Alberto de Souza Freitas

Superintendência - HRAC/USP

Rua Silvio Marchione, 3-20 Bauru SP Brasil Caixa Postal 1501 CEP 17.012-900

Tel. 551432358421

E-mail: cep@centrinho.usp.br 
Anexo 1 - Mudança de Título

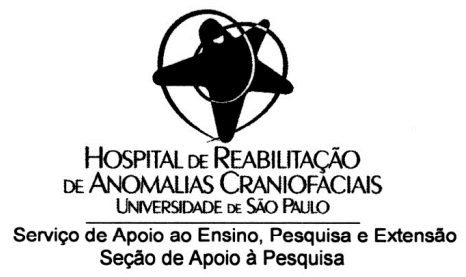

Ofício $n^{\circ}$ 350/2012-SVAPEPE-CEP

Bauru, 19 de outubro de 2012.

\section{Prezado Senhor}

As alterações solicitadas e a solicitação de alteração de título do projeto de pesquisa encaminhado a este Comitê de Ética em Pesquisa em Seres Humanos, de: "O significado das atividades expressivas e recreativas na vida da pessoa com fissura labiopalatina: uma análise baseada nos períodos de hospitalização", da pesquisadora MÁRCIA CRISTINA ALMENDROS FERNANDES MORAES, para: "Contribuições das atividades expressivas e recreativas durante a hospitalização da pessoa com fissura labiopalatina", desenvolvido sob sua orientação, foi enviado ao relator para avaliação.

O projeto de pesquisa foi aprovado Ad Referendum pelo coordenador do Comitê, considerando que não existem infrações éticas pendentes.

Solicitamos a V.Sa. a gentileza de comunicar o parecer à pesquisadora e anexar o presente ofício ao projeto pois o mesmo será necessário para futura publicação do trabalho.

A pesquisadora fica responsável pela entrega na Seção de Apoio a Pesquisa do SVAPEPE dos relatórios semestrais, bem como, comunicar ao CEP todas as alterações que possam ocorrer no projeto.

Informamos que após o recebimento do trabalho concluído, este Comitê enviará o parecer final para publicação do trabalho.

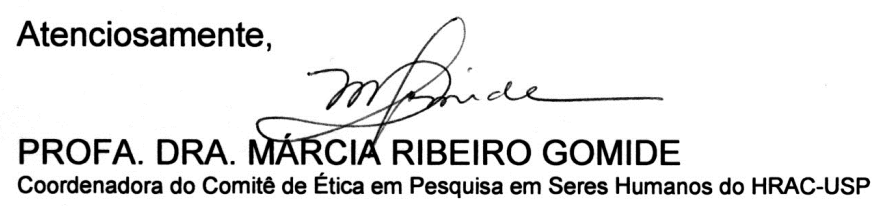

IImo. Sr.

DR. JOSÉ ALBERTO DE SOUZA FREITAS

Superintendência - HRAC/USP

Rua Silvio Marchione, 3-20 Bauru SP Brasil CEP 17.012-900

Tel. 55143235842

E-mail: cep@centrinho.usp.br 
Anexo 2 Planilha geral dos sujeitos entrevistados

\begin{tabular}{|c|c|c|c|c|c|c|c|c|c|c|}
\hline $\begin{array}{l}\text { Número } \\
\text { da } \\
\text { entrevista }\end{array}$ & $\begin{array}{c}\text { Iniciais } \\
\text { dos nomes }\end{array}$ & Sexo & Idade & $\begin{array}{c}\text { Classificação } \\
\text { da fissura }\end{array}$ & $\begin{array}{c}\text { Quantidade } \\
\text { de cirurgias } \\
\text { realizadas }\end{array}$ & $\begin{array}{c}\text { Classificaçãa } \\
\text { Socioeconômica }\end{array}$ & $\begin{array}{l}\text { Tempo de } \\
\text { tratamento } \\
\text { em anos }\end{array}$ & $\begin{array}{l}\text { Inicio do } \\
\text { tratamento }\end{array}$ & Estado & Escolaridade \\
\hline 1 & JDFC & $\mathrm{F}$ & 22 & Unilateral & 7 & BS & 23 & $27 / 05 / 87$ & MG & Ensino Médio Completo \\
\hline 2 & FRA & $\mathrm{F}$ & 19 & Unilateral & 5 & BS & 20 & $26 / 11 / 90$ & SP & Ensino Fundamental Incompleto \\
\hline 3 & CSO & $\mathrm{F}$ & 21 & Bilateral & 14 & $\mathrm{BI}$ & 21 & $25 / 07 / 89$ & SP & Ensino Médio Completo \\
\hline 4 & LMJ & M & 19 & Unilateral & 13 & BI & 19 & $26 / 07 / 91$ & SP & Ensino Médio Completo \\
\hline 5 & JWA & M & 16 & Bilateral & 5 & BS & 16 & 23/06/94 & SP & Ensino Médio Incompleto \\
\hline 6 & PHAC & M & 23 & Unilateral & 9 & $\mathrm{BI}$ & 23 & $06 / 02 / 87$ & MG & Ensino Médio Completo \\
\hline 7 & OACA & M & 18 & Bilateral & 17 & BS & 19 & $24 / 09 / 91$ & SP & Ensino Médio Completo \\
\hline 8 & SCG & $\mathrm{F}$ & 18 & Bilateral & 10 & BS & 19 & 19/11/91 & SP & Superior Incompleto \\
\hline 9 & EVGJ & M & 18 & Unilateral & 9 & BS & 19 & $11 / 06 / 91$ & SP & Superior Incompleto \\
\hline 10 & LFM & M & 15 & Unilateral & 7 & BS & 16 & 03/08/94 & SP & Ensino Médio Incompleto \\
\hline 11 & DES & M & 18 & Unilateral & 8 & MI & 18 & $12 / 08 / 92$ & SP & Ensino Médio Completo \\
\hline 12 & SLAB & $\mathrm{F}$ & 18 & Unilateral & 11 & BS & 19 & $17 / 12 / 91$ & SP & Ensino Médio Incompleto \\
\hline 13 & WSB & M & 18 & Unilateral & 9 & BS & 18 & 07/08/92 & SP & Superior Incompleto \\
\hline 14 & AMST & $\mathrm{F}$ & 17 & Unilateral & 9 & BS & 18 & $21 / 10 / 92$ & SP & Ensino Médio Incompleto \\
\hline 15 & VGS & $\mathrm{F}$ & 17 & Bilateral & 12 & BS & 18 & 08/09/92 & SP & Superior Incompleto \\
\hline 16 & TMJ & M & 15 & Unilateral & 8 & BI & 15 & 02/03/95 & SP & Ensino Médio Incompleto \\
\hline 17 & LSN & M & 21 & Unilateral & 7 & BS & 22 & $08 / 12 / 88$ & SP & Ensino Médio Completo \\
\hline 18 & PR & $\mathrm{F}$ & 16 & Unilateral & 5 & BS & 16 & $09 / 12 / 94$ & SP & Ensino Médio Incompleto \\
\hline 19 & GRO & M & 21 & Unilateral & 8 & BS & 22 & $06 / 10 / 88$ & SP & Ensino Médio Incompleto \\
\hline 20 & AVSB & M & 19 & Unilateral & 13 & BS & 18 & $12 / 05 / 92$ & ES & Ensino Médio Completo \\
\hline 21 & SST & M & 18 & Bilateral & 10 & BS & 18 & $02 / 06 / 92$ & SP & Ensino Médio Incompleto \\
\hline 22 & ESF & $\mathrm{F}$ & 19 & Unilateral & 9 & BI & 19 & $25 / 06 / 91$ & SP & Ensino Médio Incompleto \\
\hline 23 & FOV & $\mathrm{F}$ & 14 & Bilateral & 11 & MI & 15 & 05/10/95 & SP & Ensino Médio Incompleto \\
\hline 24 & LFSC & M & 19 & Unilateral & 7 & BS & 20 & $02 / 10 / 90$ & MG & Superior Incompleto \\
\hline 25 & FMC & M & 20 & Bilateral & 11 & BS & 20 & $17 / 05 / 90$ & MG & Ensino Médio Incompleto \\
\hline 26 & RPL & M & 23 & Bilateral & 10 & MI & 23 & $31 / 08 / 87$ & SP & Superior Incompleto \\
\hline 27 & KGFA & $\mathrm{F}$ & 17 & Unilateral & 6 & MI & 17 & $11 / 02 / 93$ & RJ & Ensino Médio Incompleto \\
\hline
\end{tabular}


continuação

Planilha geral dos sujeitos entrevistados

\begin{tabular}{|c|c|c|c|c|c|c|c|c|c|c|}
\hline $\begin{array}{l}\text { Número } \\
\text { da } \\
\text { entrevista }\end{array}$ & $\begin{array}{c}\text { Iniciais } \\
\text { dos nomes }\end{array}$ & Sexo & Idade & $\begin{array}{c}\text { Classificação } \\
\text { da fissura }\end{array}$ & $\begin{array}{c}\text { Quantidade } \\
\text { de cirurgias } \\
\text { realizadas }\end{array}$ & $\begin{array}{c}\text { Classificação } \\
\text { Socioeconômica }\end{array}$ & $\begin{array}{l}\text { Tempo de } \\
\text { tratamento } \\
\text { em anos }\end{array}$ & $\begin{array}{c}\text { Inicio do } \\
\text { tratamento }\end{array}$ & Estado & Escolaridade \\
\hline 28 & EDS & $\mathrm{M}$ & 23 & Bilateral & 13 & $\mathrm{BS}$ & 23 & $04 / 06 / 87$ & MG & Superior Completo \\
\hline 29 & RADC & M & 20 & Bilateral & 10 & BS & 20 & $11 / 10 / 90$ & SP & Ensino Médio Completo \\
\hline 30 & JMF & M & 19 & Unilateral & 9 & BS & 19 & 30/07/91 & SP & Ensino Médio Incompleto \\
\hline 31 & BBF & M & 20 & Unilateral & 7 & MI & 20 & $31 / 01 / 90$ & SP & Ensino Médio Completo \\
\hline 32 & FSC & $\mathrm{F}$ & 20 & Unilateral & 19 & MI & 20 & $12 / 10 / 90$ & SP & Superior Incompleto \\
\hline 33 & AACP & M & 15 & Bilateral & 13 & BS & 15 & $13 / 02 / 95$ & SP & Ensino Médio Incompleto \\
\hline 34 & FOG & M & 23 & Unilateral & 7 & BS & 23 & $12 / 11 / 87$ & SP & Ensino Médio Incompleto \\
\hline 35 & MDGL & $\mathrm{F}$ & 16 & Bilateral & 11 & BS & 17 & 06/10/93 & SP & Ensino Médio Incompleto \\
\hline 36 & MRL & M & 21 & Unilateral & 14 & MI & 21 & $12 / 07 / 89$ & SP & Ensino Médio Completo \\
\hline 37 & CHBF & M & 23 & Bilateral & 6 & BS & 23 & $01 / 10 / 87$ & SP & Ensino Médio Completo \\
\hline 38 & WCM & M & 21 & Bilateral & 11 & BS & 21 & $25 / 01 / 89$ & SP & Ensino Médio Completo \\
\hline 39 & BLC & $\mathrm{F}$ & 14 & Unilateral & 14 & $\mathrm{BI}$ & 13 & 27/02/97 & ES & Ensino Fundamental Incompleto \\
\hline 40 & EAS & M & 19 & Unilateral & 12 & BS & 19 & $25 / 06 / 91$ & MG & Ensino Médio Completo \\
\hline 41 & HRCF & M & 23 & Bilateral & 14 & BS & 23 & $25 / 06 / 87$ & SP & Superior Incompleto \\
\hline 42 & LJO & M & 21 & Unilateral & 9 & BS & 20 & $16 / 02 / 90$ & SP & Ensino Médio Incompleto \\
\hline 43 & JWS & M & 16 & Unilateral & 7 & BS & 16 & 02/08/94 & MG & Ensino Fundamental Incompleto \\
\hline 44 & MCS & $\mathrm{F}$ & 21 & Unilateral & 9 & $\mathrm{BS}$ & 21 & 05/06/89 & SP & Superior Incompleto \\
\hline 45 & BMM & $\mathrm{F}$ & 20 & Bilateral & 20 & $\mathrm{BS}$ & 20 & 20/07/90 & MG & Ensino Médio Completo \\
\hline 46 & MOM & M & 22 & Unilateral & 6 & BS & 19 & 05/03/91 & MG & Ensino Fundamental Incompleto \\
\hline 47 & IPN & M & 20 & Bilateral & 8 & BS & 19 & 08/03/91 & SP & Ensino Médio Completo \\
\hline 48 & SAF & M & 22 & Unilateral & 13 & $\mathrm{BS}$ & 21 & $30 / 03 / 89$ & SP & Ensino Médio Completo \\
\hline 49 & WCM & M & 22 & Unilateral & 8 & BS & 21 & $25 / 01 / 89$ & SP & Ensino Médio Incompleto \\
\hline 50 & CCSS & M & 17 & Unilateral & 9 & BS & 16 & $22 / 06 / 94$ & MG & Ensino Fundamental Incompleto \\
\hline 51 & DLC & M & 20 & Unilateral & 12 & BS & 20 & $27 / 11 / 90$ & MG & Superior Incompleto \\
\hline 52 & CAA & M & 18 & Unilateral & 10 & BS & 17 & 28/01/93 & SP & Superior Incompleto \\
\hline 53 & SALR & M & 16 & Unilateral & 9 & MI & 16 & 13/07/94 & SP & Ensino Médio Incompleto \\
\hline
\end{tabular}


Continuação

Planilha geral dos sujeitos entrevistados

\begin{tabular}{|c|c|c|c|c|c|c|c|c|c|}
\hline $\begin{array}{l}\text { Número } \\
\text { da } \\
\text { entrevista }\end{array}$ & $\begin{array}{c}\text { Iniciais } \\
\text { dos nomes }\end{array}$ & Estuda? & Trabalha? & Escolaridade das Mães & Escolaridade dos Pais & $\begin{array}{l}\mathbf{N}^{\circ} \text { de } \\
\text { irmãos }\end{array}$ & $\begin{array}{l}\text { Irmãos } \\
\text { com } \\
\text { fissura? }\end{array}$ & Estado civil & Religião \\
\hline 1 & JDFC & $\mathrm{S}$ & $\mathrm{S}$ & Ensino fundamental incompleto & Ensino fundamental completo & 2 & $\mathrm{~N}$ & Solteiro & Evangélica \\
\hline 2 & FRA & $\mathrm{N}$ & S & Não sabe & Ensino fundamental completo & 2 & $S$ & Solteiro & Evangélica \\
\hline 3 & CSO & $\mathrm{N}$ & $S$ & Ensino fundamental incompleto & Ensino fundamental incompleto & 6 & $\mathrm{~N}$ & Enrolado & Evangélica \\
\hline 4 & LMJ & $\mathrm{S}$ & $\mathrm{N}$ & Ensino fundamental completo & Ensino fundamental completo & 4 & $\mathrm{~N}$ & Solteiro & Católica \\
\hline 5 & JWA & $S$ & $\mathrm{~N}$ & Ensino fundamental completo & Ensino fundamental completo & 2 & $\mathrm{~N}$ & Solteiro & Católica \\
\hline 6 & PHAC & $S$ & $S$ & Ensino médio completo & Ensino médio completo & 1 & $\mathrm{~S}$ & Solteiro & Evangélica \\
\hline 7 & OACA & $S$ & $S$ & Ensino médio completo & Ensino médio completo & 0 & $\mathrm{~N}$ & Solteiro & Evangélica \\
\hline 8 & SCG & $S$ & $\mathrm{~N}$ & Ensino fundamental incompleto & Ensino médio completo & 0 & $\mathrm{~N}$ & Solteiro & Espírita \\
\hline 9 & EVGJ & $S$ & $S$ & Ensino médio incompleto & Ensino fundamental incompleto & 5 & $\mathrm{~N}$ & Solteiro & Evangélica \\
\hline 10 & LFM & S & $\mathrm{N}$ & Ensino médio incompleto & Não sabe & 1 & $\mathrm{~N}$ & Solteiro & Não tem \\
\hline 11 & DES & $\mathrm{N}$ & $S$ & Ensino fundamental incompleto & Ensino superior completo & 1 & $\mathrm{~N}$ & Solteiro & Católica \\
\hline 12 & SLAB & $\mathrm{N}$ & $\mathrm{S}$ & Ensino médio completo & Ensino superior completo & 2 & $\mathrm{~N}$ & Solteiro & Evangélica \\
\hline 13 & WSB & $S$ & S & Ensino fundamental incompleto & Ensino fundamental incompleto & 2 & $\mathrm{~N}$ & Solteiro & Católica \\
\hline 14 & AMST & $S$ & $\mathrm{~N}$ & Ensino superior incompleto & Ensino superior completo & 0 & $\mathrm{~N}$ & Solteiro & Evangélica \\
\hline 15 & VGS & $S$ & $S$ & Ensino médio completo & Ensino médio incompleto & 1 & $\mathrm{~N}$ & Solteiro & Católica \\
\hline 16 & TMJ & $S$ & $\mathrm{~N}$ & Ensino fundamental incompleto & Não sabe & 2 & $\mathrm{~N}$ & Solteiro & Católica \\
\hline 17 & LSN & $\mathrm{N}$ & $S$ & Ensino fundamental incompleto & Ensino fundamental incompleto & 1 & $\mathrm{~N}$ & Solteiro & Católica \\
\hline 18 & PR & $S$ & $\mathrm{~N}$ & Ensino médio completo & Não sabe & 1 & $\mathrm{~N}$ & Solteiro & Católica \\
\hline 19 & GRO & $\mathrm{N}$ & S & Ensino médio completo & Não sabe & 1 & $\mathrm{~N}$ & Solteiro & Evangélica \\
\hline 20 & AVSB & $S$ & S & Ensino médio completo & Não sabe & 4 & $\mathrm{~N}$ & Solteiro & Evangélica \\
\hline 21 & SST & $S$ & $S$ & Ensino fundamental incompleto & Ensino fundamental incompleto & 1 & $\mathrm{~N}$ & Solteiro & Católica \\
\hline 22 & ESF & $\mathrm{N}$ & S & Ensino médio completo & Não sabe & 8 & $\mathrm{~N}$ & Solteiro & Evangélica \\
\hline 23 & FOV & $\mathrm{S}$ & $\mathrm{N}$ & Ensino médio completo & Ensino médio completo & 2 & $\mathrm{~N}$ & Solteiro & Católica \\
\hline 24 & LFSC & $\mathrm{S}$ & $\mathrm{N}$ & Ensino médio completo & Ensino médio completo & 1 & $\mathrm{~N}$ & Solteiro & Católica \\
\hline 25 & FMC & $\mathrm{N}$ & S & Ensino fundamental incompleto & Ensino fundamental completo & 2 & $\mathrm{~S}$ & Solteiro & Católica \\
\hline 26 & RPL & $\mathrm{S}$ & $\mathrm{N}$ & Ensino médio completo & Ensino superior incompleto & 2 & $S$ & Solteiro & Católica \\
\hline 27 & KGFA & $S$ & $\mathrm{~N}$ & Ensino superior completo & Ensino superior completo & 1 & $\mathrm{~N}$ & Solteiro & Católica \\
\hline
\end{tabular}


Continuação

Planilha geral dos sujeitos entrevistados

\begin{tabular}{|c|c|c|c|c|c|c|c|c|c|}
\hline $\begin{array}{c}\text { Número } \\
\text { da } \\
\text { entrevista }\end{array}$ & $\begin{array}{l}\text { Iniciais } \\
\text { dos nomes }\end{array}$ & Estuda? & Trabalha? & Escolaridade das Mães & Escolaridade dos Pais & $\begin{array}{l}\mathrm{N}^{\circ} \text { de } \\
\text { irmãos }\end{array}$ & $\begin{array}{c}\text { Irmãos } \\
\text { com } \\
\text { fissura? }\end{array}$ & Estado civil & Religião \\
\hline 28 & EDS & $\mathrm{N}$ & $S$ & Ensino superior completo & Ensino médio completo & 6 & $\mathrm{~N}$ & Solteiro & Católica \\
\hline 29 & RADC & $\mathrm{N}$ & S & Ensino fundamental incompleto & Ensino fundamental incompleto & 1 & $\mathrm{~N}$ & Solteiro & Evangélica \\
\hline 30 & JMF & S & $\mathrm{N}$ & Ensino médio completo & Ensino fundamental completo & 1 & $\mathrm{~N}$ & Solteiro & Católica \\
\hline 31 & BBF & $\mathrm{N}$ & S & Ensino superior completo & Não sabe & 4 & $\mathrm{~N}$ & Solteiro & Católica \\
\hline 32 & FSC & $S$ & S & Ensino superior completo & Ensino superior completo & 1 & $\mathrm{~N}$ & Solteiro & Católica \\
\hline 33 & $\mathbf{A A C P}$ & $S$ & $\mathrm{~N}$ & Ensino superior completo & Ensino superior completo & 2 & $\mathrm{~N}$ & Solteiro & Católica \\
\hline 34 & FOG & $\mathrm{N}$ & S & Ensino fundamental completo & Ensino médio incompleto & 3 & $\mathrm{~N}$ & Solteiro & Evangélica \\
\hline 35 & MDGL & S & $\mathrm{N}$ & Ensino fundamental completo & Ensino fundamental completo & 1 & $\mathrm{~N}$ & Solteiro & Católica \\
\hline 36 & MRL & $\mathrm{N}$ & S & Ensino superior completo & Não sabe & 2 & $\mathrm{~N}$ & Solteiro & Católica \\
\hline 37 & CHBF & $\mathrm{N}$ & S & Não sabe & Ensino fundamental incompleto & 7 & $\mathrm{~N}$ & Solteiro & Evangélica \\
\hline 38 & WCM & S & $\mathrm{N}$ & Ensino fundamental incompleto & Ensino fundamental completo & 3 & S & Solteiro & Católica \\
\hline 39 & BLC & S & $\mathrm{N}$ & Ensino fundamental incompleto & Ensino fundamental incompleto & 4 & $\mathrm{~N}$ & Solteiro & Evangélica \\
\hline 40 & EAS & $\mathrm{N}$ & S & Ensino fundamental incompleto & Ensino fundamental incompleto & 1 & $\mathrm{~N}$ & Solteiro & Católica \\
\hline 41 & HRCF & $S$ & $S$ & Ensino superior completo & Ensino superior completo & 0 & $\mathrm{~N}$ & Solteiro & Espírita \\
\hline 42 & LJO & $\mathrm{N}$ & S & Ensino fundamental incompleto & Ensino fundamental incompleto & 5 & $\mathrm{~N}$ & Casado & Evangélica \\
\hline 43 & JWS & S & $\mathrm{N}$ & Não sabe & Não sabe & 0 & $\mathrm{~N}$ & Solteiro & Evangélica \\
\hline 44 & MCS & S & S & Ensino fundamental incompleto & Ensino fundamental incompleto & 4 & $\mathrm{~N}$ & Solteiro & Evangélica \\
\hline 45 & BMM & $\mathrm{N}$ & S & Ensino médio completo & Ensino médio completo & 4 & $\mathrm{~N}$ & Solteiro & Católica \\
\hline 46 & MOM & $\mathrm{N}$ & $S$ & Ensino fundamental incompleto & Ensino fundamental completo & 1 & $\mathrm{~N}$ & Solteiro & Evangélica \\
\hline 47 & IPN & $\mathrm{N}$ & $S$ & Não sabe & Não sabe & 2 & $\mathrm{~N}$ & Solteiro & Católica \\
\hline 48 & SAF & $\mathrm{N}$ & $S$ & Ensino médio completo & Ensino médio completo & 2 & $\mathrm{~N}$ & Solteiro & Católica \\
\hline 49 & WCM & S & S & Ensino fundamental completo & Ensino médio completo & 3 & $\mathrm{~S}$ & Solteiro & Católica \\
\hline 50 & CCSS & $S$ & $\mathrm{~N}$ & Ensino médio completo & Ensino médio completo & 4 & $\mathrm{~N}$ & Solteiro & Católica \\
\hline 51 & DLC & $S$ & $S$ & Ensino médio completo & Ensino fundamental completo & 2 & $\mathrm{~S}$ & Solteiro & Evangélica \\
\hline 52 & CAA & $S$ & S & Ensino fundamental incompleto & Ensino médio completo & 2 & $\mathrm{~N}$ & Solteiro & Espírita \\
\hline 53 & SALR & $S$ & $\mathrm{~N}$ & Ensino superior completo & Ensino superior completo & 1 & $\mathrm{~N}$ & Solteiro & Evangélica \\
\hline
\end{tabular}

Continua 
Continuação

Planilha geral dos sujeitos entrevistados

\begin{tabular}{|c|c|c|c|c|c|c|c|c|c|}
\hline $\begin{array}{l}\text { Número } \\
\text { da } \\
\text { entrevista }\end{array}$ & $\begin{array}{c}\text { Iniciais } \\
\text { dos nomes }\end{array}$ & $\begin{array}{c}\text { Atividade } \\
\text { física/esportes }\end{array}$ & $\begin{array}{l}\text { Atividades } \\
\text { de lazer }\end{array}$ & $\begin{array}{l}\text { Lazer em grupo ou } \\
\text { individual }\end{array}$ & $\begin{array}{c}\text { Quantas } \\
\text { vezes } \\
\text { internado }\end{array}$ & Atividade marcante & $\begin{array}{l}\text { Contribuição } \\
\text { a vida }\end{array}$ & $\begin{array}{c}\text { Crescimento com } \\
\text { atividades }\end{array}$ & $\begin{array}{c}\text { Convivência } \\
\text { familiares }\end{array}$ \\
\hline 1 & JDFC & $S$ & $\mathrm{~S}$ & Grupal & $5 \mathrm{x}$ & Expressão plástica & $\mathrm{S}$ & social & Ótima \\
\hline 2 & FRA & $\mathrm{N}$ & $S$ & Grupal & $3 x$ & Jogos & S & social & Ruim \\
\hline 3 & CSO & $\mathrm{S}$ & $S$ & Grupal e individual & $9 x$ & Expressão dramática & $S$ & social & Regular \\
\hline 4 & LMJ & $\mathrm{N}$ & S & Grupal & $8 x$ & Dinâmica de grupo & S & social & Ótima \\
\hline 5 & JWA & $\mathrm{S}$ & $S$ & Grupal & $3 x$ & Expressão dramática & $S$ & social & Ótima \\
\hline 6 & PHAC & $\mathrm{N}$ & S & Grupal e individual & $6 x$ & Todas & S & ocupacional & Boa \\
\hline 7 & OACA & $\mathrm{N}$ & $S$ & Grupal e individual & $8 x$ & Leituras & $\mathrm{S}$ & social & Ótima \\
\hline 8 & SCG & $\mathrm{N}$ & $S$ & Grupal & $8 x$ & Expressão corp. e musical & $S$ & social & Ótima \\
\hline 9 & EVGJ & $\mathrm{N}$ & $S$ & Grupal e individual & $5 x$ & Dinâmica de grupo & $S$ & escolar & Ótima \\
\hline 10 & LFM & S & $S$ & não realiza & $4 x$ & Todas & $\mathrm{N}$ & não contribuiu & Boa \\
\hline 11 & DES & $S$ & $S$ & Grupal & $4 x$ & Expressão dramática & S & social & Boa \\
\hline 12 & SLAB & $\mathrm{N}$ & $S$ & Grupal & $6 x$ & Todas & $S$ & social & Ótima \\
\hline 13 & WSB & $S$ & $S$ & Grupal & $6 x$ & Nenhuma & S & social & Boa \\
\hline 14 & AMST & $S$ & $S$ & Grupal & $5 x$ & Dinâmica de grupo & $S$ & social & Ótima \\
\hline 15 & VGS & $\mathrm{N}$ & $S$ & Grupal e individual & $8 x$ & Expressão corp. e musical & S & famíliar & Ótima \\
\hline 16 & TMJ & $S$ & $S$ & Grupal & $5 x$ & Jogos & S & social & Ótima \\
\hline 17 & LSN & $S$ & $S$ & Grupal e individual & $5 x$ & Expressão plástica & $S$ & ocupacional & Boa \\
\hline 18 & PR & $S$ & $S$ & Grupal & $3 x$ & Jogos & $\mathrm{N}$ & não contribuiu & Ótima \\
\hline 19 & GRO & S & $S$ & Grupal e individual & $5 x$ & Expressão plástica & S & não sabe & Boa \\
\hline 20 & AVSB & S & $S$ & Individual & $8 x$ & Dinâmica de grupo & $S$ & social & Ótima \\
\hline 21 & SST & S & $S$ & Grupal e individual & $7 x$ & Dinâmica de grupo & S & social & Boa \\
\hline 22 & ESF & $\mathrm{N}$ & $S$ & Grupal & $5 x$ & Expressão dramática & S & social & Ruim \\
\hline 23 & FOV & $\mathrm{S}$ & $S$ & Grupal e individual & $6 x$ & Jogos & S & social & Ótima \\
\hline 24 & LFSC & $S$ & $S$ & Grupal e individual & $4 x$ & Jogos & S & social & Ótima \\
\hline 25 & FMC & S & $S$ & Grupal e individual & $8 x$ & Jogos & $S$ & social & Ótima \\
\hline 26 & RPL & S & $S$ & Grupal e individual & $8 x$ & Nenhuma & S & ocupacional & Ótima \\
\hline 27 & KGFA & S & $S$ & Grupal e individual & $3 x$ & Expressão plástica & S & social & Boa \\
\hline
\end{tabular}


continuação

Planilha geral dos sujeitos entrevistados

\begin{tabular}{|c|c|c|c|c|c|c|c|c|c|}
\hline $\begin{array}{c}\text { Número } \\
\text { da } \\
\text { entrevista }\end{array}$ & $\begin{array}{l}\text { Iniciais } \\
\text { dos nomes }\end{array}$ & $\begin{array}{c}\text { Atividade } \\
\text { física/esportes }\end{array}$ & $\begin{array}{l}\text { Atividades } \\
\text { de lazer }\end{array}$ & $\begin{array}{l}\text { Lazer em grupo ou } \\
\text { individual }\end{array}$ & $\begin{array}{c}\text { Quantas } \\
\text { vezes } \\
\text { internado }\end{array}$ & Atividade marcante & $\begin{array}{c}\text { Contribuição } \\
\text { a vida }\end{array}$ & $\begin{array}{c}\text { Crescimento com } \\
\text { atividades }\end{array}$ & $\begin{array}{c}\text { Convivência } \\
\text { familiares }\end{array}$ \\
\hline 28 & EDS & $\mathrm{S}$ & $\mathrm{S}$ & Grupal e individual & $9 x$ & Leituras & $S$ & social & Ótima \\
\hline 29 & RADC & $\mathrm{N}$ & S & Grupal e individual & $8 x$ & Todas & S & social & Ótima \\
\hline 30 & JMF & S & S & Individual & $6 x$ & Jogos & $S$ & escolar & Ótima \\
\hline 31 & BBF & $S$ & $S$ & Grupal e individual & $4 x$ & Expressão dramática & $S$ & ocupacional & Ótima \\
\hline 32 & FSC & $\mathrm{N}$ & $\mathrm{N}$ & Grupal e individual & $10 \mathrm{x}$ & Dinâmica de grupo & S & ocupacional & Ótima \\
\hline 33 & AACP & $S$ & S & Grupal e individual & $7 x$ & Dinâmica de grupo & S & escolar & Ótima \\
\hline 34 & FOG & $\mathrm{N}$ & $S$ & Grupal e individual & $5 x$ & Dinâmica de grupo & S & social & Ótima \\
\hline 35 & MDGL & S & S & Grupal e individual & $7 x$ & Dinâmica de grupo & S & social & Regular \\
\hline 36 & MRL & $S$ & S & Grupal & $10 \mathrm{x}$ & Expressão dramática & S & afetiva & Ótima \\
\hline 37 & CHBF & $S$ & $S$ & Grupal e individual & $6 x$ & Dinâmica de grupo & S & social & Regular \\
\hline 38 & WCM & S & S & Grupal e individual & $7 x$ & Nenhuma & $S$ & social & Ótima \\
\hline 39 & BLC & S & S & Grupal & $7 x$ & Expressão dramática & $S$ & social & Ótima \\
\hline 40 & EAS & S & S & Grupal & $7 x$ & Expressão dramática & S & social & Boa \\
\hline 41 & HRCF & S & S & Grupal e individual & $10 \mathrm{x}$ & Expressão plástica & S & social & Regular \\
\hline 42 & LJO & S & S & Grupal & $4 \mathrm{x}$ & Jogos & S & afetiva & Boa \\
\hline 43 & JWS & S & $S$ & Grupal e individual & $4 x$ & Expressão plástica & $S$ & escolar & Ótima \\
\hline 44 & MCS & $S$ & S & Grupal e individual & $6 x$ & Expressão plástica & $S$ & social & Ótima \\
\hline 45 & ВMM & $S$ & $S$ & Grupal e individual & $11 \mathrm{x}$ & Expressão dramática & S & social & Ótima \\
\hline 46 & MOM & S & $S$ & Grupal e individual & $3 x$ & Expressão plástica & S & social & Ótima \\
\hline 47 & IPN & S & $S$ & Grupal e individual & $6 x$ & Jogos & S & social & Ótima \\
\hline 48 & SAF & $\mathrm{N}$ & S & Grupal e individual & $8 x$ & Expressão corp. e musical & $S$ & social & Ótima \\
\hline 49 & WCM & S & S & Grupal e individual & $6 x$ & Expressão corp. e musical & S & afetiva & Ótima \\
\hline 50 & CCSS & S & S & Grupal e individual & $5 x$ & Jogos & $\mathrm{N}$ & não contribuiu & Ótima \\
\hline 51 & DLC & S & S & Grupal e individual & $6 x$ & Jogos & S & social & Ótima \\
\hline 52 & CAA & S & S & Grupal e individual & $5 x$ & Dinâmica de grupo & S & escolar & Ótima \\
\hline 53 & SALR & $\mathrm{N}$ & S & Grupal e individual & $9 x$ & Jogos & $\mathrm{S}$ & social & Ótima \\
\hline
\end{tabular}


Continuação

Planilha geral dos sujeitos entrevistados

\begin{tabular}{|c|c|c|c|c|c|c|c|c|c|c|}
\hline $\begin{array}{c}\text { Número } \\
\text { da } \\
\text { entrevista }\end{array}$ & $\begin{array}{c}\text { Iniciais } \\
\text { dos } \\
\text { nomes }\end{array}$ & $\begin{array}{c}\text { Convivências } \\
\text { colegas trabalho }\end{array}$ & $\begin{array}{l}\text { Convivências } \\
\text { escola }\end{array}$ & $\begin{array}{c}\text { Convivência com } \\
\text { professores }\end{array}$ & $\begin{array}{c}\text { Convivência com } \\
\text { superiores }\end{array}$ & $\begin{array}{l}\text { Convivência } \\
\text { c/ colegas e } \\
\text { conhecidos }\end{array}$ & $\begin{array}{c}\text { Vida } \\
\text { profissional }\end{array}$ & $\begin{array}{c}\text { Convivência } \\
\text { social }\end{array}$ & $\begin{array}{l}\text { Relacionamento } \\
\text { com sexo oposto }\end{array}$ & $\begin{array}{c}\text { Estágio da } \\
\text { reabilitação }\end{array}$ \\
\hline 1 & JDFC & Ótima & Ótima & Não Respondeu & Não respondeu & Boa & Ótima & Ótima & Bom & Ótimo \\
\hline 2 & FRA & Boa & Não estuda & Não estuda & Boa & Regular & Boa & Boa & Ótimo & Ótimo \\
\hline 3 & CSO & Ótima & Não estuda & Não estuda & Ruim & Regular & Ruim & Boa & Ruim & Ótimo \\
\hline 4 & LMJ & Não Trabalha & Ótima & Boa & Não trabalha & Ótima & Não trabalha & Ótima & Ótimo & Ótimo \\
\hline 5 & JWA & Não Trabalha & Ótima & Ótima & Não trabalha & Ótima & Não trabalha & Ótima & Ótimo & Bom \\
\hline 6 & PHAC & Boa & Boa & Ótima & Boa & Boa & Boa & Regular & Bom & Ótimo \\
\hline 7 & OACA & Boa & Boa & Ótima & Boa & Boa & Ótima & Ótima & Ótimo & Ótimo \\
\hline 8 & SCG & Não Trabalha & Boa & Boa & Não trabalha & Boa & Não trabalha & Boa & Regular & Bom \\
\hline 9 & EVGJ & Ótima & Ótima & Ótima & Ótima & Ótima & Ótima & Ótima & Ótimo & Ótimo \\
\hline 10 & LFM & Não Trabalha & Ruim & Ótima & Não trabalha & Ótima & Não trabalha & Regular & Bom & Não respondeu \\
\hline 11 & DES & Não convive & Não estuda & Não estuda & Ótima & Boa & Boa & Boa & Bom & Ótimo \\
\hline 12 & SLAB & Ótima & Não estuda & Não estuda & Ótima & Ótima & Boa & Boa & Regular & Ótimo \\
\hline 13 & WSB & Não respondeu & Boa & Boa & Boa & Boa & Boa & Regular & Ótimo & Ótimo \\
\hline 14 & AMST & Não Trabalha & Boa & Boa & Não trabalha & Ótima & Não trabalha & Boa & Ótimo & Regular \\
\hline 15 & VGS & Boa & Ótima & Boa & Boa & Boa & Boa & Boa & Regular & Bom \\
\hline 16 & TMJ & Não Trabalha & Boa & Boa & Não trabalha & Regular & Não trabalha & Boa & Bom & Ótimo \\
\hline 17 & LSN & Boa & Não estuda & Não estuda & Regular & Ótima & Regular & Boa & Regular & Ótimo \\
\hline 18 & PR & Não Trabalha & Ótima & Ótima & Não trabalha & Ótima & Não trabalha & Ótima & Ótimo & Ótimo \\
\hline 19 & GRO & Boa & Não estuda & Não estuda & Boa & Boa & Boa & Boa & Ruim & Bom \\
\hline 20 & AVSB & Ótima & Ótima & Ótima & Ótima & Ótima & Ótima & Ótima & Ótimo & Bom \\
\hline 21 & SST & Boa & Ótima & Boa & Boa & Ótima & Boa & Boa & Bom & Bom \\
\hline 22 & ESF & Ótima & Não estuda & Não estuda & Ótima & Ótima & Ótima & Regular & Bom & Ótimo \\
\hline 23 & FOV & Não Trabalha & Ótima & Boa & Não trabalha & Ótima & Não trabalha & Ótima & Ótimo & Ótimo \\
\hline 24 & LFSC & Não Trabalha & Boa & Boa & Não trabalha & Boa & Não trabalha & Boa & Bom & Bom \\
\hline 25 & FMC & Boa & Ótima & Ruim & Boa & Ótima & Boa & Ótima & Ótimo & Ótimo \\
\hline 26 & RPL & Boa & Boa & Boa & Ótima & Ótima & Não trabalha & Boa & Regular & Bom \\
\hline 27 & KGFA & Não Trabalha & Ótima & Ótima & Não trabalha & Ótima & Não trabalha & Boa & Bom & Ótimo \\
\hline
\end{tabular}


Continuação

Planilha geral dos sujeitos entrevistados

\begin{tabular}{|c|c|c|c|c|c|c|c|c|c|c|}
\hline $\begin{array}{l}\text { Número } \\
\text { da } \\
\text { entrevista }\end{array}$ & $\begin{array}{l}\text { Iniciais } \\
\text { dos } \\
\text { nomes }\end{array}$ & $\begin{array}{l}\text { Convivências } \\
\text { colegas trabalho }\end{array}$ & $\begin{array}{c}\text { Convivências } \\
\text { escola }\end{array}$ & $\begin{array}{l}\text { Convivência com } \\
\text { professores }\end{array}$ & $\begin{array}{l}\text { Convivência com } \\
\text { superiores }\end{array}$ & $\begin{array}{l}\text { Convivência } \\
\text { c/ colegas e } \\
\text { conhecidos }\end{array}$ & $\begin{array}{c}\text { Vida } \\
\text { profissional }\end{array}$ & $\begin{array}{c}\text { Convivência } \\
\text { social }\end{array}$ & $\begin{array}{l}\text { Relacionamento } \\
\text { com sexo oposto }\end{array}$ & $\begin{array}{l}\text { Estágio da } \\
\text { reabilitação }\end{array}$ \\
\hline 28 & EDS & Boa & Não estuda & Não estuda & Boa & Boa & Boa & Ótima & Bom & Ótimo \\
\hline 29 & RADC & Boa & Não estuda & Não estuda & Boa & Boa & Boa & Boa & Ótimo & Ótimo \\
\hline 30 & JMF & Não Trabalha & Ótima & Boa & Não trabalha & Ótima & Não trabalha & Ótima & Regular & Ótimo \\
\hline 31 & BBF & Ótima & Não estuda & Não estuda & Ótima & Boa & Ótima & Boa & Ótimo & Bom \\
\hline 32 & FSC & Ótima & Boa & Boa & Ótima & Ótima & Boa & Ótima & Ótimo & Bom \\
\hline 33 & AACP & Não Trabalha & Ótima & Ótima & Não trabalha & Ótima & Não trabalha & Ótima & Bom & Bom \\
\hline 34 & FOG & Boa & Não estuda & Não estuda & Boa & Boa & Ótima & Boa & Ótimo & Ótimo \\
\hline 35 & MDGL & Não Trabalha & Ótima & Regular & Não trabalha & Ótima & Não trabalha & Boa & Ótimo & Ótimo \\
\hline 36 & MRL & Boa & Não estuda & Não estuda & Boa & Ótima & Boa & Ótima & Ótimo & Ótimo \\
\hline 37 & CHBF & Ótima & Não estuda & Não estuda & Ótima & Boa & Ótima & Boa & Regular & Ótimo \\
\hline 38 & WCM & Não Trabalha & Ótima & Boa & Não trabalha & Ótima & Não trabalha & Ótima & Ótimo & Ótimo \\
\hline 39 & BLC & Não Trabalha & Boa & Ótima & Não trabalha & Ótima & Não trabalha & Ótima & Bom & Ótimo \\
\hline 40 & EAS & Ótima & Não estuda & Não estuda & Ótima & Ótima & Ótima & Ótima & Bom & Ótimo \\
\hline 41 & HRCF & Boa & Ruim & Boa & Boa & Regular & Regular & Regular & Ruim & Bom \\
\hline 42 & LJO & Ótima & Não estuda & Não estuda & Ótima & Ótima & Ótima & Boa & Bom & Ótimo \\
\hline 43 & JWS & Não Trabalha & Ótima & Boa & Não trabalha & Ótima & Não trabalha & Ótima & Bom & Ótimo \\
\hline 44 & MCS & Não Trabalha & Regular & Ótima & Ótima & Ótima & Ótima & Regular & Ótimo & Bom \\
\hline 45 & BMM & Ótima & Não estuda & Não estuda & Boa & Ótima & Boa & Ótima & Ótimo & Ótimo \\
\hline 46 & MOM & Ótima & Não estuda & Não estuda & Boa & Ótima & Ótima & Ótima & Ótimo & Ótimo \\
\hline 47 & IPN & Ótima & Não estuda & Não estuda & Boa & Boa & Ótima & Ótima & Ótimo & Ótimo \\
\hline 48 & SAF & Boa & Não estuda & Não estuda & Ótima & Boa & Boa & Boa & Bom & Ótimo \\
\hline 49 & WCM & Ótima & Ótima & Ótima & Ótima & Ótima & Ótima & Boa & Ótimo & Ótimo \\
\hline 50 & CCSS & Não Trabalha & Ótima & Ótima & Não trabalha & Ótima & Não trabalha & Ótima & Ótimo & Ótimo \\
\hline 51 & DLC & Ótima & Ótima & Ótima & Ótima & Boa & Boa & Ótima & Bom & Ótimo \\
\hline 52 & CAA & Ótima & Ótima & Ótima & Ótima & Boa & Boa & Ótima & Bom & Ótimo \\
\hline 53 & SALR & Não Trabalha & Ótima & Regular & Não trabalha & Boa & Não trabalha & Boa & Bom & Ótimo \\
\hline
\end{tabular}


Anexo 3 - Roteiro da Entrevista

\section{ROTEIRO DA ENTREVISTA}

Data

Horário: Início

Término

\section{IDENTIFICAÇÃO:}

Nome:

$\operatorname{Sexo}($ ) M( ) F

Data de Nascimento $\mathrm{N}^{\mathrm{o}}$ pront $-\overline{\text { Idade }}$

Classificação da Fissura:

CSE:

Início do tratamento no Hospital: Residência (cidade/UF):

Cirurgias realizadas:

\section{ENTREVISTA:}

Escolaridade:

Ocupação / Profissão:

Pessoas que residem na mesma casa:

Família: Mãe: Idade Escolaridade:

Ocupação / Profissão:

Pai: Idade Escolaridade:

Ocupação / Profissão:

Tem irmãos: ( )Não （ ） Sim.

Algum tem fissura labiopalatina: ( )Não （ ） Sim

Estado Civil: ( ) Solteiro ( ) Casado （ ) Outro

Tem filhos: ( ) Não （ ) Sim. Idade(s) dos filhos:

Algum tem fissura labiopalatina: ( ) Não ( ) Sim.

\section{Com relação às suas atividades sociais:}

Participa ativamente de movimentos religiosos: ( ) Não （ ) Sim. Comente

Pratica esportes regularmente: ( )Não （ ) Sim. Comente

Quais suas atividades de lazer?

Quais outras atividades você realiza?

Quantas vezes você ficou hospitalizado?

Quais atividades expressivas e recreativas você se lembra de ter participado durante as internações? 
Continuação

Qual delas você considera mais marcante?

Você considera que essas atividades o ajudaram na sua vida? ( )Não （ ) Sim. Por que?:

\section{Como você avalia:}

Sua convivência com familiares: ( ) Ótima （）Boa （）Regular （ ) Ruim. Por que?

Com colegas da escola ou trabalho: ( ) Ótima ( ) Boa ( ) Regular （ ) Ruim. Por que?

Comprofessores ou superiores: ( ) Ótima （ ) Boa （ ) Regular （ ) Ruim. Por que?

Com demais colegas e conhecidos: ( ) Ótima （ ) Boa （）Regular （ ) Ruim. Por que?

Sua vida ocupacional/profissional: ( ) Ótima （ ) Boa （ ) Regular （ ) Ruim. Por que?

Sua vida social: ( ) Ótima （ ) Boa （）Regular （ ) Ruim. Por que?

Seu relacionamento com pessoas do sexo oposto: ( ) Ótimo （ ) Bom （ ) Regular （ ) Ruim. Por que?

Seu estágio de reabilitação: ( ) Ótimo ( ) Bom ( ) Regular （ ) Ruim. Por que?

Comente sobre a sua experiência durante as internações, pensando nas atividades expressivas e recreativas das quais você participou: 


\section{Anexo 4 - Termo de Consentimento Livre e Esclarecido}

\section{TERMO DE CONSENTIMENTO LIVRE E ESCLARECIDO}

Pelo presente instrumento que atende às exigências legais, o sr. (a)

responsável pelo paciente * , portador da cédula de identidade minuciosa deste documento, devidamente explicado pelo pesquisador em seus mínimos detalhes, ciente dos procedimentos aos quais será submetido, não restando quaisquer dúvidas a respeito do lido e explicado, firma seu CONSENTIMENTO LIVRE E ESCLARECIDO concordando em participar da pesquisa:

\section{O SIGNIFICADO DAS ATIVIDADES EXPRESSIVAS E RECREATIVAS NA VIDA DA PESSOA COM FISSURA LABIOPALATINA: UMA ANÁLISE BASEADA NOS PERÍODOS DE HOSPITALIZAÇÃO,}

realizada por: MARCIA CRISTINA ALMENDROS FERNANDES MORAES n ${ }^{\circ}$. do Conselho: 7448-TO, sob orientação do prof. dr. JOSÉ ALBERTO DE SOUZA FREITAS; que tem como objetivo: investigar junto aos adolescentes e jovens adultos com fissura labiopalatina o significado das atividades expressivas e recreativas oferecidas durante a hospitalização, na sua vida familiar, social, emocional, escolar e ocupacional. Tais conhecimentos são indisponíveis na literatura, motivando a realização deste trabalho, com a finalidade de contribuir para o processo de reabilitação. O procedimento para coleta dos dados será uma única entrevista, com duração média de 40 minutos, realizada individualmente com os pacientes de 18 a 23 anos e, com o paciente acompanhado por um responsável se sua idade for entre 14 e 17 anos. O local de aplicação será uma sala do Serviço de Educação e Terapia Ocupacional do HRAC/USP, em ambiente com privacidade. Inicialmente, após a apresentação do projeto e concordância na participação pelo paciente e/ou responsável, será solicitada autorização para gravação da entrevista. Em seguida, frente ao mesmo, serão preenchidos pelo pesquisador a partir dos registros no prontuário clínico, os dados de identificação: classificação socioeconômica, classificação da fissura, início do tratamento no Hospital e cirurgias realizadas. As demais questões, algumas abertas e outras com alternativas, serão apresentadas gradativamente, seguindo um roteiro semi-estuturado, para serem respondidas verbalmente pelo paciente.

Esta pesquisa não acarretará nenhum ônus ou risco para os envolvidos, tendo estes a liberdade de deixar de participar dela a qualquer momento, inclusive deixar de responder as questões elaboradas, sem prejuízo na continuidade do seu tratamento no Hospital.

Caso o paciente e/ou responsável queiram apresentar reclamações em relação a sua participação na pesquisa, poderão entrar em contato com o Comitê de Ética em Pesquisa em Seres Humanos, do HRAC/USP, pelo endereço Rua Silvio Marchione, 3-20 no Serviço de Apoio ao Ensino, Pesquisa e Extensão ou pelo telefone (14) 3235-8421.

Fica claro que o sujeito da pesquisa ou seu representante legal, pode a qualquer momento retirar seu CONSENTIMENTO LIVRE E ESCLARECIDO e deixar de participar desta pesquisa e ciente de que todas as informações prestadas tornar-se-ão confidenciais e guardadas por força de sigilo profissional (Art. $7^{\circ}$ do Código de Ética Fisioterapia e Terapia Ocupacional VIII).

Por estarem de acordo assinam o presente termo.

Bauru-SP,

Assinatura do Sujeito da Pesquisa ou responsável
Márcia Cristina Almendros Fernandes Moraes

Pesquisador

* A SER PREENCHIDO, SE O SUJEITO DA PESQUISA NÃO FOR O PACIENTE.

Nome do Pesquisador Responsável:

Márcia Cristina Almendros Fernandes MoraesEndereço Institucional: Rua Silvio Marchione, 3-20 Cidade: Bauru Estado: SP CEP: 17.012-900 Caixa postal 1501 Telefone: tel:: 55 -14 - 3235 8421 E-mail: uep_projeto@centrinho.usp.br 